\title{
4 Aspects of Skepticism in the Genesius Plays by Lope de Vega and Jean de Rotrou
}

\subsection{Lope de Vega, Lo fingido verdadero (c. 1608/1621)}

Lope de Vega's (1562-1635) 'tragicomedia' Lo fingido verdadero [The Feigned True or the True Feigned] first appeared in print in 1621 in Madrid in the sixteenth volume of his comedias, accompanied by a dedication letter addressed to none other than Tirso de Molina. ${ }^{487}$ Believed to have been written around $1608,{ }^{488}$ around the time Lope published his poetological (and polemic) text Arte nuevo de hacer comedias en este tiempo [New Art of Writing Plays in This Time] (1609), and originally titled El mejor representante [The Greatest Actor], ${ }^{489}$ the play is one of several of Lope's dramatic works that focus on the lives of saints, a relatively minor theme within his extensive dramatic

487 [Félix Lope de Vega y Carpio], Decimasexta Parte de las Comedias de Lope de Vega Carpio ..., Madrid 1621, fols. 259v-284v ("Dedica[toria] al R. P. Presentado F. Graviel Tellez Religioso de nuestra Señora de la Merced, Redencion de Cautiuos,” fols. 259v-260v). All references to the drama are from the edition: Félix Lope de Vega y Carpio, Lo fingido verdadero, ed. Maria Teresa Cattaneo, Rome 1992, and will be cited parenthetically by verse numbers in the text. Although the editor indicates 1620 as the year of the first publication of Decimasexta Parte (p. 51), the copy to which she refers (Biblioteca Nacional de España, Madrid, signature R/23476) must have appeared only in 1621: it differs from the other copies in the Biblioteca Nacional (signatures $\mathrm{R} / 14109, \mathrm{R} / 13867, \mathrm{R} / 25145$ ) only by the front page indicating 1620 , which, however, belongs to the 13th partial edition of the comedias published this very year - the title page of the volume is provided with a damaged, glued note stating 'Trezena' -, furthermore in the Preliminaries the 'Suma de Tasa' is dated 27 September 1621. (Cf. regarding this also Maria Grazia Profeti, La collezione Diferentes Autores, 2nd ed., Kassel 1988, p. 196 [in Appendix 3, pp. 172-211, considering the various editions, there is a list of the 25 partes of Lope's comedias]; see as well the indication in Urszula Aszyk, “ “. . . pon el teatro, y prevén / lo necesario .... Hacia una reconstrucción de la puesta en escena original de Lo fingido verdadero,” in: Felipe B. Pedraza Jiménez/Rafael González Cañal/Elena Marcello [eds.], El corral de comedias: espacio escénico, espacio dramático, Almagro 2006, pp. 159-180, here p. 159, n. 1).

488 Cf. Sylvanus G. Morley/Courtney Bruerton, The Chronology of Lope de Vega's 'Comedias': With a Discussion of Doubtful Attributions, the Whole Based on a Study of His Strophic Versification, New York 1966 (repr. of the edition New York/London 1940), p. 364.

489 Cf. p. 198 as well as the reference in Marcelino Menéndez Pelayo ("Lo fingido verdadero" [1894], in: Marcelino Menéndez Pelayo, Estudios sobre el teatro de Lope de Vega, ed. Enrique Sánchez Reyes, 6 vols., Santander 1949, vol. 1: Autos, comedias de la sagrada escritura y de santos [Edición nacional de las obras completas de Menéndez Pelayo, ed. Miguel Artigas, vol. 29], pp. 264-283, here p. 264). The reference to the former title is also articulated in the comedia's closing verses: "OCTAVIO: Aquí acaba la comedia / del mejor representante” (v. 3122 f.).

¿ Open Access. (C) 2019 Leonie Pawlita, published by De Gruyter. (c) BY-NC-ND This work is licensed under a Creative Commons Attribution-NonCommercial-NoDerivatives 4.0 International License.

https://doi.org/10.1515/9783110660586-005 
oeuvre. ${ }^{490}$ As Ilse Nolting-Hauff states, the play provides an early example of 'play within a play,' has a metatheatrical dimension, and 'is characterized by an astonishing similarity to $20^{\text {th }}$-century dramatic forms. ${ }^{491}$ She further continues that it 'is the first play of the Spanish Baroque that uses the metaphor of the theater of the world and already expresses with great virtuosity the particularly Baroque theme of seeming and being in literature. ${ }^{492}$ David Castillejo, e.g., praised the play as "la obra cumbre, el Hamlet, de Lope." ${ }^{493}$ Despite this, the play has received comparatively little scholarly attention. ${ }^{494}$

490 Robert R. Morrison mentions (in terms of authenticity of authorship with reference to Morley/Bruerton, The Chronology of Lope de Vega's 'Comedias' [cf. note 488]) 21 comedias de santos that were certainly written by Lope de Vega, four that were probably written by him, as well as 29 others of questionable authorship (Robert R. Morrison, Lope de Vega and the 'Comedia de Santos', New York 2000, pp. 321-325).

491 Ilse Nolting-Hauff, "Lope de Vega: Lo fingido verdadero," in: Volker Roloff/Harald Wentzlaff-Eggebert (eds.), Das spanische Theater: Vom Mittelalter bis zur Gegenwart, Düsseldorf 1988, pp. 70-89, here p. 70 ("Darüber hinaus zeichnet es sich durch [...] eine [...] erstaunliche[re] Verwandtschaft zu Dramenformen des 20. Jahrhunderts aus.”).

492 P. 83 (“[...] Lo fingido verdadero [ist] das erste Welttheaterdrama des spanischen Barock [...] und [setzt] die spezifisch barocke Sein- und Schein-Thematik bereits mit außerordentlicher Virtuosität literarisch um[setzt] [...].”).

493 David Castillejo, Las cuatrocientas comedias de Lope: Catálogo crítico, Madrid 1984, p. 25. (However, he interprets it as a turning point regarding the main focus of Lope's dramatic work: "[...] divide toda su producción teatral en dos partes: pasa de ser un escritor amatorio a ser un escritor religioso" [p. 73], which had been influenced by his private love life, the relationship with the actress Micaela Luján: "Traza la crisis psíquica del propio Lope, als trasladar todo su amor físico por Micaela a un amor espiritual por un Dios masculino” [p. 25]); cf. the reference to Castillejo's observation also in Victor Dixon, “'Ya tienes la comedia prevenida ... la imagen de la vida': Lo fingido verdadero,” Cuadernos de teatro clásico 11 (1999), pp. 53-72, here p. 53, and Morrison, Lope de Vega and the 'Comedia de Santos' (cf. note 490), p. 194.

494 This can at least be said with regard to German Romance Studies. Only Barbara Simerka, "Metatheater and Skepticism" (cf. note 2), discusses an explicit connection to skepticism (including a relation with Le Véritable Saint Genest that will be discussed later here). The study by Ilse Nolting-Hauff, "Lo fingido verdadero" (cf. note 491), is still fundamental. Urzsula Aszyk, "Hacia una reconstrucción de la puesta en escena original de Lo fingido verdadero" (cf. note 487), deals with the contemporary scenographic representation possibilities and reconstructs the production of Lo fingido verdadero on the corral stage, more precisely the Corral del Príncipe in Madrid. The drama is discussed in terms of metatheatrical aspects in particular in: Elaine M. Canning, "Lo fingido verdadero as Metaplay,” in: Elaine M. Canning, Lope de Vega's 'Comedias de tema religioso': Re-creations and Re-presentations, Woodbridge 2004, pp. 95-127; Elvezio Canonica, "De la ficción de la verdad a la verdad de la ficción en Lo fingido verdadero de Lope de Vega," in: Irene AndresSuárez/José Manuel López de Abiada/Pedro Ramírez Molas (eds.), El teatro dentro del teatro: Cervantes, Lope, Tirso y Calderón, Madrid 1997, pp. 99-110; Maria Teresa Cattaneo, "La doctrina dramática en Lo fingido verdadero y su proyección europea,” in: Felipe B. Pedraza Jiménez/Rafael González Cañal/Elena E. Marcello (eds.), El Arte nuevo de hacer comedias en su contexto europeo, 
Lo fingido verdadero is an adaptation of the life of Saint Genesius (Spanish: Ginés) that Lope de Vega probably gleaned from Jesuit priest Pedro de

Cuenca 2010, pp. 179-193; Florence D’Artois, “El teatro en el teatro en Lo fingido verdadero. Nuevo intento de aproximación," in: Christophe Couderc/Benoit Pellistrandi (eds.), "Por discreto y por amigo": Mélanges offert à Jean Canavaggio, Madrid 2005, pp. 181-189; V. Dixon, "'Ya tienes la comedia prevenida ..." (cf. note 493); Susan L. Fischer, "Lope’s Lo fingido verdadero and the Dramatization of the Theatrical Experience,” Revista hispánica moderna 39 (1976/1977), pp. 156-166; Hugh Gaston Hall, "Illusion et vérité dans deux pièces de Lope de Vega: La Fiction vraie et Le Chien du jardinier," in: Marie-Thérèse Jones-Davies (ed.), Vérité et illusion dans le thêâtre au temps de la Renaissance, Paris 1983, pp. 41-54; Guillermo Serés, "Consideraciones metateatrales en algunas comedias de Lope de Vega," Teatro de palabras 5 (2011), pp. 87-117; Alan S. Trueblood, "Role-Playing and the Sense of Illusion in Lope de Vega," Hispanic Review 32 (1964), pp. 305-318; cf. as well William Egginton, How the World Became a Stage: Presence, Theatricality, and the Question of Modernity, New York 2003 and Dakin Matthews, "Metatheatricality and Conversion in Lope's Lo fingido verdadero," in: Susan Paun de García/ Donald R. Larson (eds.), Religious and Secular Theater in Golden Age Spain: Essays in Honor of Donald T. Dietz, New York 2017, pp. 77-90. It is discussed in the context of 'hagiographic drama' in: Elma Dassbach, La comedia hagiográfica del Siglo de Oro español: Lope de Vega, Tirso de Molina y Calderón de la Barca, New York 1997; Morrison, Lope de Vega and the 'Comedia de Santos' (cf. note 490), pp. 186-195; Gerd F. Müller, Studien zum hagiographischen Theater Lope de Vegas: Exemplarische Interpretation von sechs 'comedias de vidas de santos', Diss. Cologne 1970, pp. 130-150. In connection with the contemporary debates on licitud it is explored in: Isabel Ibáñez, "El teatro hagiográfico en el centro de la controversia sobre la licitud de la comedia. Una poética 'en acto': Lo fingido verdadero de Lope de Vega," in: Marc Vitse/Antonio Ortiz García (eds.), Homenaje a Henri Guerreiro: La hagiografia entre historia y literatura en la España de la Edad Media y del Siglo de Oro, Madrid 2005, pp. 725-739; Gerhard Poppenberg, "La licitud del teatro. Los argumentos del debate y el argumento del drama. A partir de Lo fingido verdadero de Lope de Vega,” in: Christoph Strosetzki (ed.), Teatro español del Siglo de Oro: Teoría y Práctica, Frankfurt am Main 1998, pp. 283-304. With regard to a comparative perspective (especially with Rotrou's drama) cf. Maria Teresa Cattaneo, “Transformaciones de Ginés, actor y mártir,” in: Almudena García González/Felipe B. Pedraza Jiménez (eds.), La Comedia de Santos: Coloquio Internacional (Almagro, 1, 2 y 3 de diciembre de 2006), Almagro 2008, pp. 255-268; Urszula Aszyk, "Lo fingido verdadero de Lope de Vega y The Roman Actor de Philip Massinger. Puntos comunes y diferencias,” in: Joaquín Álvarez Barrientos/Óscar Cornado Bernal et al. (eds.), En buena compañia: Estudios en honor de Luciano García Lorenzo, Madrid 2009, pp. 67-77; Sibylla Laemmel, "Zur Adaptation einer 'comedia de santo' in Frankreich. Le véritable saint Genest von Rotrou und Lo fingido verdadero von Lope de Vega," in: Küpper/Wolfzettel (eds.), Diskurse des Barock (cf. note 278), pp. 463-490; Noël M. Valis, "Rotrou and Lope de Vega. Two Approaches to Saint-Genest," Canadian Review of Comparative Literature/Revue Canadienne de Littérature Comparée 6 (1979), pp. 346-359; Mary Ann Frese Witt, "From Saint Genesius to Kean. Actors, Martyrs, and Metatheater," Comparative Drama 43 (2009), pp. 19-44. See, furthermore: John V. Bryans, "Fortune, Love and Power in Lope de Vega's Lo fingido verdadero," Revista Canadiense de Estudios Hispánicos 9 (1985), pp. 133-148; Maria Teresa Cattaneo, "Il teatro del mondo e il 
Ribadeneyra's hagiographic collection Flos sanctorum (1599-1601). ${ }^{495}$ According to legend, Genesius, known since the $13^{\text {th }}$ century as the patron saint of actors, was a popular actor in Rome during the reign of Diocletian (r. 284-305), famous for portraying and ridiculing Christianity and Christian rites on stage. Ribadeneyra describes him as,

[...] farsante, insigne chocarrero y gracioso, [...] muy enemigo de Christianos el qual, parte por su mala inclinacion, y por la mala vida que trahia (como suelen los de aquel oficio) y parte por dar gusto al Emperador, y entretenimiento al pueblo, se dio mucho a perseguir a los Cristianos, y hazer burla dellos, y para esto quiso entender los misterios de nuestra santa Fè, y las ceremonias del Baptismo, para representarlos en sus comedias, y mouer a risa a los circunstantes. ${ }^{496}$

In the midst of a mocking portrayal of baptism, performed before the emperor, he is said to have actually converted to Christianity and then passionately

mondo del teatro. Lettura di Lo fingido verdadero di Lope de Vega," in: Lope de Vega, Lo fingido verdadero, ed. M. Cattaneo (cf. note 487), pp. 7-41; Menéndez Pelayo, "Lo fingido verdadero" (cf. note 489); Elena di Pinto, “'Entre bestias anda el juego’ o la tradición animalística clásica en Lo fingido verdadero de Lope de Vega," Cuadernos de filología clásica: Estudios latinos 17 (1999), pp. 199-217; Elida Maria Szarota, "Lope de Vegas Lo fingido verdadero," in: Szarota, Künstler, Grübler und Rebellen: Studien zum europäischen Märtyrerdrama des 17. Jahrhunderts, Bern/Munich 1967, pp. 24-42; Gustavo Umpierre, "Una comedia metafísica de Lope de Vega: Lo fingido verdadero," La Torre 28 (1980), pp. 161-192.

495 Pedro de Ribadeneyra, "La vida de san Gines el Representante, Martir," in: Pedro de Ribadeneyra, Flos sanctorum, o libro de las vidas de los santos (1599-1601), 2 vols., Madrid 1624, vol. 2, pp. 359b-361b (see the corresponding reference in Menéndez Pelayo ["Lo fingido verdadero" (cf. note 489), p. 266], which the subsequent research usually refers to). Cf. also the depiction of the vita in the equally popular collection of saints' lives by Alonso de Villegas ("De san Gines representante martyr," in: Alonso de Villegas, Flos Sanctorum, y Historia general de la vida y hechos de Iesu Christo, Dios y señor nuestro, y de todos los Santos de que reza y haze fiesta la Yglesia Catolica, Madrid 1588, fols. 120v-121r; there, Genesius is mentioned among "Los santos Extrauagantes," “[...] q[ue] ni son de los contenidos en el Breuiario Romano reformado, ni de los proprios de España” [fol. 62r;]); see, furthermore, the "Passio Sancti Genesii ex mimo martyris," in: Thierry Ruinart (ed.), Acta primorum Martyrum sincera et selecta, Paris 1689, pp. 283 f.; as well as the corresponding entries in Johann Evangelist Stadler/Franz Joseph Heim/Johann Nepomuk Ginal (eds.), Vollständiges Heiligen-Lexikon: Oder Lebensgeschichten aller Heiligen, Seligen etc., 5 vols., Hildesheim/New York 1975 (repr. of the edition Augsburg 1858-1882), vol. 2, pp. 371 f.; The Benectine Monks of St. Augustine's Abbey, Ramsgates (eds.), The Book of Saints: A Dictionary of Servants of God Canonized by the Catholic Church, London 1921, p. 121; on the origin and reception of the legend as a whole, see Bertha von der Lage, Studien zur Genesiuslegende, 2 vols., Berlin 1898-1899.

496 Ribadeneyra, "La vida de san Gines” (cf. note 495), p. 360a. 
affirmed his new faith. As a result Diocletian had him arrested and tortured, and ultimately beheaded. ${ }^{497}$

497 Genesius is commemorated on 25th August, but the details given in the sources about his exact year of death differ; according to Ribadeneyra, he died in 303. In point of fact, there are several saints by the name of Genesius being venerated in the Catholic Church (Stadler et al. [eds.], Heiligen-Lexikon [cf. note 495], vol. 2, pp. 370-373] lists fourteen saints named Genesius [on Saint Genesius of Arles, see below note 582 ['San Ginés escribano']) and there are also additional 'Genesius-figures,' i.e. actor-martyrs, namely, Gelasius or Gelasinus, Ardalio, Porphyrius, and Philemon. Gelasius/Gelasinus, who is believed to have been martyred around 297 CE in Heliopolis in Phoenicia, and Porphyrius, whose martyrdom is said to have happened around $361 \mathrm{CE}$ under Emperor Julian, according to legend, like Genesius, confessed Christianity all of a sudden while mocking Christian baptism on stage. According to one version, the former is said to have been stoned to death by the people, according to another he was beheaded, and the latter is said to finally have been, after severe torture, executed by decapitation. Ardalio, whose martyrdom is told to have taken place in an unspecified city in Asia Minor during the reign of Maximian around 300 $\mathrm{CE}$, was in the midst of mocking Christian customs on stage, but then while playing a Christian steadfastly professing his faith, he suddenly became a Christian and declared himself as such. He is said to have been burnt alive. (See Von der Lage, Studien zur Genesiuslegende [cf. note 495], vol. 1, pp. 10-18; the entries in Stadler et al. [eds.], Heiligen-Lexikon [cf. note 495], vol. 1, pp. 304 f. [Ardalio]; vol. 4, p. 967 [7. Porphyrius]; vol. 2, p. 364 [6. Gelasius]). The vita of Philemon, which was given a prominent dramatized adaptation in Jakob Bidermann's play Philemon Martyr (1610-1620), differs from the above stories, which are obviously very similar to that of the Roman Genesius (Von der Lage assumes that they all originated from an Oriental archetype, that the Roman church transferred the legend to Rome and chose the name Genesius as a symbol of reincarnation [Studien zur Genesiuslegende (cf. note 495), vol. 1, p. 21 and p. 39]). Nevertheless, I will summarize it here: Philemon's conversion and martyrdom takes place in Antinoë in Egypt during the Diocletian persecution of Christians. Philemon is paid to disguise himself as the deacon or lecturer Apollonius and sacrifice to the gods instead of him. Before the governor Arianus, Philemon professes to be a Christian. Arianus does not recognize him at first because of his disguise, and, when he is finally identified by his brother as Philemon, he considers Philemon's confession to be a well-performed farce. After Philemon continues to profess Christianity, he is condemned by Arianus to torture and finally to death by beheading, as well as Apollonius who in the meantime has been seized and is openly professing his faith. According to the legend, even the praeses Arianus becomes a Christian: he had ordered that Philemon be shot with arrows, but all of them missed, including one that hit Arianus in the eye. This wound was suddenly healed when Arianus entered the tomb of the martyrs whose execution he had ordered, and he promptly converted to Christianity. (Cf. Stadler et al. [eds.], Heiligen-Lexikon [cf. note 495], vol. 4, pp. 884 f. [2. Philemon] as well as "Martyrium Sanctorum Apollonii \& sociorum ejus," in: Ruinart [ed.], Acta primorum Martyrum sincera [cf. note 495], pp. 539 ff.) At the end of his Genesius narrative, Ribadeneyra mentions Porphyry and Ardalio as further examples of miraculous conversions of actors, and, furthermore, refers to another such case: "Y san Agustin escriuiendo a Alipio, epistola sesenta y siete, cuenta lo q[ue] acontecio a otro farsante, que se dezía Dioscoro, y era gra[n] burlador de los Christianos, y al cabo co[n]la enfermedad de su hija, y otros açotes, se hizo Christiano, y fue sieruo 
In Lope's comedia, the life of Genesius only takes up the third act. The vita's core motif, however, the idea that fiction becomes reality, is negotiated in the course of the play in many different ways. It is not only about the transition from lo fingido ('the feigned') to lo verdadero ('the true'), ${ }^{498}$ but rather, as the title reflects, about the reciprocal dynamics between the two. ${ }^{499}$ Lo fingido verdadero expresses the relativity of the boundary between fiction and truth, appearance and being, illusion and reality; themes that harbor affinities to the discourse of skepticism. This dynamic will be laid out in the summary of the plot that follows. A further analysis will pay special attention to the 'position' implied in Lope's drama regarding this problem.

The comedia's first act describes Diocleciano's ascent from simple soldier to emperor. Lope's main source for this element of the plot is commonly assumed to be the Historia imperial y cesárea [Imperial History or Lives of the Roman Emperors] (1545) written by Pedro Mexía. ${ }^{500}$ The play opens with Marcio, Curio,

del Señor [. . .]" ("La vida de san Gines” [cf. note 495], p. 361b). However, the mentioned "farsante [...] Dioscoro," whose mysterious conversion Augustine describes in a letter to Alypius, is most likely not a 'comedian' but a physician, or rather the medicus princeps. The mistake in profession probably results from a corrupt manuscript of the Augustinian letters, more precisely the confusion of the terms architheater and archiater (Latin: 'senior physician'). The corresponding letter printed in Patrologia Latina as letter 227, not 67 reads: "Archiater etiam Dioscorus christianus fidelis est, simul gratiam consecutus; audi etiam quemadmodum: [...].”, the annotation then reads: "Edd., Architheater. At Mss. melioris notae, Archiater, id est medicus princeps" (Augustinus, Ep. CCXXVII "Augustinus Alypio seni, de Gabiniano recens baptizato, et de Dioscoro miraculis converso ad Christianismum," in: Patrologiae cursus completus [...]: Series Latina, ed. Jacques Paul Migne, 217 vols., Paris 1844-1855, vol. 33 [1865 (1st ed. 1845)]: Sancti Aurelii Augustini, Hipponensis Episcopi, Opera Omnia [II], cols. 1012 f., here col. 1012). Ribadeneyra probably took the reference to the converted 'actor' Dioscorus from the Martyrologium Romanum. There, in the notes provided by Caesar Baronius on April 14 (among others, commemoration day for Saint Ardalion) of the extended edition of 1586 the following sentence can be found: "legimus huius generis celebre exemplum de Dioscoro architheatro apud S. Augustinum epistula 67 ad Alipium" (Martyrologium Romanum, ad novam Kalendarii rationem, et Ecclesiasticae historiae veritatem restitutum, ed. Cesare Baronio, Rome 1586, p. 166, note E [my italics]; for the reference to this passage in the Martyrologium Romanum and the divergence in the Augustine letter, see Von der Lage, Studien zur Genesiuslegende [cf. note 495], p. 13, n. 18).

498 It should be noted that, in the context of the desengaño-concept expressed at the end of the comedia, comparable to the final argument of La vida es sueño, it is precisely this perspective that is ultimately given.

499 This interplay is difficult to express in translations of the title.

500 Pedro Mexía, Historia imperial y cesárea (1545), Antwerp 1552; the chapters on Caro (in the play: Aurelio) and his sons Carino and Numeriano can be found on fols. 126r-127v ("“ . .] vida del emperador Caro solo deste nombre, y de Carino y Numeriano sus hijos, que tambien se llamaron Augustos [...]" [fol. 126r]), those on Diocleciano and Maximiano on fols. 127v-131v 
Maximiano, and Diocleciano lamenting the poor pay and lack of supplies they are receiving as soldiers fighting with Emperor Aurelio Caro in a war in Mesopotamia, while back in Rome Aurelio's son Carino, who they despise, is reigning in his father's absence. Only Numeriano, Aurelio's second son, who they feel, in contrast to his vicious brother, would make a worthy emperor, prevents them from mutiny. ${ }^{501}$ Camila, a young woman, approaches them offering bread for sale. Diocleciano has no money but jokes that he would pay her back for it and show his gratitude when he was Emperor of Rome (“[...] yo te le

(“[...] vida del emperador Diocleciano solo deste nombre, y Aurelio Maximiano emperadores [...]” [fol. 127v]); as authorities Mexía mentions, among others, the late antique Roman historians Flavius Vopiscus, Sextus Aurelius, and Eutropius (4th century), the Christian historians Paulus Orosius (c. 385-418) and Eusebius (c. 260-340), Isidore of Seville (c. 556-636), and the Italian humanist Julius Pomponius Laetus (1428-1498) (fol. 127v b and fol. 131v b). Although the events depicted in Lope's first act are highly condensed, especially with regard to their chronological order, they are to a large extent in line with historical facts, which were as follows: the assassination of the last Severan emporer Severus Alexander (r. 222-235) in 235 was followed by the rise to power of former soldier Maximinus Thrax (r. 235-238). The next fifty years saw some twenty emperors rise and fall from power, most of whom were former generals who used the support of the legions to gain control. The rule of each one sometimes only lasted a few months until they were usurped and ousted by their successors. During this period the Roman Empire was in a permanent state of war on several fronts, with the conflicts with the Teutons in the north and the Persian Sasanid Empire in the east being of particular and lasting significance. (Cf. Alexander Demandt, "Diokletian als Reformer," in: Alexander Demandt/Andreas Goltz/Heinrich Schlange-Schöningen [eds.], Diokletian und die Tetrarchie: Aspekte einer Zeitenwende, Berlin/New York 2004, pp. 1-9, here p. 1; Alexander Demandt, Die Spätantike: Römische Geschichte von Diocletian bis Justinian 284-565 n.Chr., 2nd ed., Munich 2007, pp. 44-57). Marcus Aurelius Carus, who had been proclaimed Roman emperor by the troops in autumn 282, died in July 283 while campaigning against the Sasanids. He had elevated his sons Carinus and Numerianus to caesars. While Numerianus was involved in the Persian war, the elder brother Carinus remained in Gaul and was in charge of the administration of the West. After Carus' death, the two brothers were appointed Augusti. Numerianus was murdered in the summer of 284 on the army's return from the east, allegedly by his father-in-law, the praetorian prefect Aper. Diocletian was proclaimed emperor by the eastern troops after Numerianus' death on 20 November 284 in Nicomedia, but was defeated by Carinus in a battle in Moesia. Carinus, however, was assassinated in 285, leaving Diocletian the sole ruler of the empire. (Cf. p. 58 as well as the entries in: Carl Andresen/Hartmut Erbse et al. [eds.], Lexikon der Alten Welt, Zurich/Stuttgart 1965, col. 548 [Carinus], col. 551 [Carus], col. 2105 [Numerianus], cols. 745 f. [Diocletian], here col. 745, and Wolfgang Kuhoff, Diokletian und die Epoche der Tetrarchie: Das römische Reich zwischen Krisenbewältigung und Neuaufbau [284-313 A.D.], Frankfurt am Main/Berlin/Bern 2001, pp. 17-27).

501 This attribution of opposing character traits is already found in Lope's source: In Mexía, Numeriano is described as "virtuoso, sabio, erudito," whereas Carino is introduced as "malo, desonesto, desordenado, y dado a todo genero de vicios" (Historia imperial y cesárea [cf. note 500], fol. 126r b). 
pagaré / cuando sea Emperador / de Roma. CAmiLA: Gracioso humor" vv. 97-99). Camila hands him the bread and prophesies: "[...] que cuando matares / un jabalí [a boar], tú serás / emperador” (vv. 117-119). Both burlas will prove to be veras in the further course of the play. A heavy storm sets in, with numerous lightning strikes. Diocleciano comforts his friend Maximiano with the words "No tengas temor / ¿Cuándo has visto Emperador / romano muerto de rayo?" (vv. 190-192), which turns out to be a prediction of what happens immediately thereafter. Emperor Aurelio, in the midst of speech wrathfully challenging the heavens, is struck by lightning and dies. ${ }^{502}$ After discovering his charred corpse, Numeriano, with the enthusiastic approval of the soldiers, takes over the command of the army as consul.

The following scene shows a change of place and register, a characteristic feature of Spanish comedia: accompanied by Celio (a servant), two musicians, and Rosarda (a woman dressed as a man), Carino roams the streets of Rome at night. ${ }^{503}$ The group engages in a conversation about the ladies who live in the area. Talking about actresses, Celio jokingly compares their performances to the life of his master. The difference consisted in the fact that their comedia lasted only one and a half hours, whereas his would last his whole life and end with death ("La diferencia sabida, / es que les dura hora y media / su comedia, y tu comedia / te dura toda la vida. / Tú representas también, / mas estás de rey

502 Vv. 194-252 (e.g.: “¿Qué furia es ésta, cielo, / con que te opones a mi brazo airado, / si montañas de hielo, / si volcanes de llamas he pasado? / ¿No ves que son ensayos / contra mis fuerzas tu granizo y rayos? / [ . . ] / Yo soy Aurelio Caro; / yo soy César de Roma; yo sustento / debajo de mi amparo / este mundo inferior; si el firmamento / es tuyo, el suelo es mío; / que así reina partido el poderío. / [. . . / Vive, Júpiter santo, / que si ponemos monte sobre monte, / que te he de dar espanto; / fulmíname después como a Tifonte, / con tal que mi venganza / ponga al poder de tu furor templanza. / A tu suprema esfera / osaré levantar mil escuadrones de gente armada y fiera. / ¡Parece que castigas mis razones! / ¡Oh, qué trueno tan fiero! / Fulminásteme, Júpiter; ya muero.”). Although Mexía also reports in his Historia imperial y cesárea that Emperor Aurelio Caro is killed by a lightning strike during his campaign against the Persians, he is not the only victim and it happens while he is gravely ill in his tent ("Pero llegando con su exercito alas riberas del rio Tigris, delos trabajos, y calor le dio vna graue enfermedad, de la qual estando muy agrauiado, sobreuino vn dia vna grande tempestad de truenos y relampagos, y cayo vn rayo en su tienda del emperador, y mato a algunos delos que enella estaua[n] y entre ellos a el mismo [. . .]" [Mexía, Historia imperial y cesárea (cf. note 500), fol. 126v a]).

503 With the characters Celio and Rosarda, there are two further typical features of 17th century Spanish theater represented: the figure of the gracioso and the woman dressed as a man. For the latter, see the passage in Lope's Arte nuevo: "Las damas no desdigan de su nombre, / y si mudaren traje, sea de modo / que pueda perdonarse, porque suele / el disfraz varonil agradar mucho" (vv. 280-283, my italics; quoted after the edition: Lope de Vega, Arte nuevo de hacer comedias en este tiempo [1609], ed. Enrique García Santo-Tomás, 2nd ed., Madrid 2009, p. 146). 
vestido / hasta la muerte, que ha sido / sombra del fin" vv. 363-370). Carino is angered by this comparison, saying that he was by no means playing a role. He was not an "emperador fingido" but a ruler "de veras" in life and in death; the law of mortal men did not apply to him:

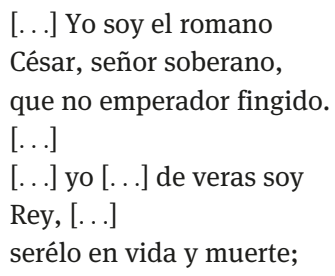

Somos los Emperadores,

[...] casi iguales a los dioses celestiales: somos del mundo señores, como ellos lo son del cielo; (vv. 392-405)

(vv. 419-423)

When Carino makes this presumptuous speech, alluding to the elevation of the Caesars into deities that was accepted in pagan Rome, and expressing a hubris similar to that expressed by his father Aurelio before his death, they are standing in front of the house of Ginés. Ginés is introduced as an actor ('representante') and in fact Carino had already used him as an example to make it clear that actors are kings only within the time limit of a theater performance, while he, however, was an 'immortal' king ("Cuando sale a hacer Ginés / un rey en una tragedia, / reinará por hora y media, / y no lo será después” vv. 399-402); furthermore, he is described in this scene as a poet, who writes comedias himself ("CELIO: [...] también es poeta / y las comedias compone” vv. 447 f.), and as an autor (theater director, producer, head of a company of actors). Carino then immediately calls for Ginés to come out to the street.

Contrary to the typical depiction of the saint's life (on which Lo fingido verdadero is based), which typically depicts Ginés as virulently anti-Christian, Lope's Genesius is presented primarily as the consummate actor, dramatist, and poet. When Carino calls him, he is in fact busy working on a comedia about the myth of Pasiphaë. Although he does not comply with Carino's request to give a spontaneous performance, he does accept the proposition to have a play about Carino and Rosarda written by a famous poet and to perform it 
himself. ${ }^{504}$ In the course of this discussion, Carino appoints him court actor, "representante imperial" (v. 508), and a dialogue then takes place that touches upon-and here the contemporary poetic discourse is resonating - the theme of the proper composition and performance of comedias. ${ }^{505}$ In a foreshadowing of events, when Ginés is asked by Carino about the women of his acting troupe, he mentions Lisarda. She was an actress who had converted to Christianity and now lived as a 'new penitent' in the mountains of Marseille ("una tenía gallarda, / que se llamaba Lisarda, / [...] / [ . .] cristiana se volvió. / [...] / Embarcóse presurosa / a ser nueva penitente / en las peñas de Marsella" vv. 472-480). The description of Lisarda is that of a 'new Mary Magdalene'506 or 'Magdalene typos,' and it further presages Ginés' own transformation. ${ }^{507}$ As will become clear, the play is replete with typologizing structures.

504 Carino does not aim for a theatrical performance of panegyric character, but rather has a comedy about jealousy in mind: Rosarda should be described as "muy discreta," whereas he should be portrayed as "muy necio y celoso" (vv. 498 f.); after that Rosarda says: "Pagaréle yo también, / porque su ingenio famoso / te pinte amado e ingrato, / y a mí de mil celos llena" (vv. 501-504).

505 "GinÉs: [. . .] hay poeta que tiene / la musa como mujer. / [. . ] / Es por lo que nos detiene, / aunque tú se lo pidieses, / hasta que el fruto declare, / pues cualquier comedia pare / al cabo de nueve meses. / [...] / CARINO: Ahora bien; busca a Aristeles [the poet who is to write the play about Carino and Rosarda] / y hárala con brevedad. / Ginés: Guardará la propiedad. / CARINO: Representa como sueles; / que yo no gusto de andar / con el arte y los precetos. / GinÉs: Cánsanse algunos discretos. / CARINo: Pues déjalos tú cansar. / Deleita el oído, y basta, / como no haya error que sea / disparate que se vea” (vv. 524-545).

506 According to a medieval legend, Mary Magdalena, together with her brother Lazarus, her sister Martha and other Christians 'miraculously' crossed the Mediterranean Sea to Marseille on a rudderless ship. She is said to have lived for thirty years in the wilderness of the SainteBaume mountains in a cave as a penitent. (Cf. the legend in Pedro de Ribadeneyra ["La vida de Santa Maria Madalena,” in: Ribadeneyra, Flos sanctorum (cf. note 495), vol. 1, pp. 460b-467b, here pp. 465b-466a]; the entry in Stadler et al. [eds.], Heiligen-Lexikon [cf. note 495], vol. 4, pp. 26-30, here pp. 28 f.).

$\mathbf{5 0 7}$ This is the interpretation of the passage given by Nolting-Hauff ("Lo fingido verdadero" [cf. note 491], p. 77), which I subscribe to. S. Laemmel, on the other hand, reads the passage about Lisarda as a biographical cipher: Marseille was often considered a place of worldly desire, and given the phonetic similarity of Marcela-Marsella, Ginés' saying these words is actually an indication of his own desire (the relationship between Ginés and Marcela will be explained further on), Lisarda's 'new penitence' refers to actress Elena Osorio, who - in analogy to Ginés' Marcela - preferred another lover to the playwright Lope de Vega, and who he indirectly slandered as a prostitute. The contemporary theater audience might actually have been more aware of the scandal about Lope de Vega and Elena Osorio than of the Magdalena 
After the encounter with Ginés, the group continues its nocturnal search for pleasures. Carino boasts of the satisfaction he feels depriving chaste, noble, and virtuous ladies of their honor, especially the wives of senators, particularly his rape of the wife of Consul Lelio. ${ }^{508}$ They abruptly encounter an enraged Lelio himself, who declares that Carino had forfeited his honor and imperial dignity, when he, the one whose duty as ruler it was to preserve and defend the honor of all, had robbed him, Lelio, of his honor. He then stabs Carino to free Rome from a 'new Nero.'509 Dying, Carino formulates the insight that he had merely played a role in a tragedy that had now come to an end and which, according to his impression, like an authentic tragedy on stage, had not lasted longer than an hour and a half:

\author{
Representé mi figura: \\ César fui, Roma, rey era; \\ acabóse la tragedia, \\ la muerte me desnudó: \\ sospecho que no duró \\ toda mi vida hora y media. \\ Poned aquestos vestidos \\ de un representante Rey, \\ pues es tan común la ley \\ a cuantos fueron nacidos, \\ adonde mi sucesor \\ los vuelva luego a tomar,
}

legend. Lope was, as Laemmel concludes, ambiguously playing here with the sublime and the profane. ("Zur Adaptation einer 'comedia de santo' in Frankreich” [cf. note 494], here pp. 481 f.). It should be noted that, considering Ginés' conversion to Christianity in the third act, the account of an actress who has become a Christian is quite significant in the development of the play and the comedia's structure, i.e., the complex preparation for this change. On the other hand, leaving aside the biographical aspect, Laemmel's interpretation of the passage as a frivolous play on words can be combined with the implications foreshadowing Ginés' conversion, in so far as this alludes, in condensed form, to the sensual love between GinésMarcela that is the focus of the second act, as well as to Ginés' eventual turning towards the 'true' Christian love.

508 "CARINO: Mucho me deleito y gusto / de quitar [. . . el honor / a una mujer casta y noble / y virtuosa, y al doble / si es mujer de senador. / [ . . ] / Celio: Mil cosas, señor, escucho; / enmienda y ejemplo toma; / que Lelio el cónsul, a quien / tanto ofendiste el honor, / supo ya tu loco amor / y su deshonra también. / [. . . / ROSARDA: Si su mujer le has forzado, / ¿es mucho que el cónsul Lelio / muestre enojo, Emperador?” (vv. 562-579). And shortly thereafter in Lelio's words: "[Soy] [u]n cónsul de tu Senado, / cuya mujer has forzado / más en decirlo después, / que en hacer tan gran maldad” (vv. 584-587).

509 Vv. 589-636 (“[. . .] quiero quitar / a Roma un nuevo Nerón” vv. 635 f.). 
porque ha de representar,

¡quiera el cielo que mejor! ${ }^{510}$

(vv. 641-654)

510 In Mexía, Carino dies in battle against Diocleciano (“[. . .] vuieron vna batalla, que fue la postrera y mas cruel, enla qual Carino fue justamente vencido y muerto" [Historia imperial y cesárea (cf. note 500), fol. 127v b]). He does not go into the details about his death. However, it should be noted that the version in Lope's drama was probably based on an anonymous socalled Epitome de Caesaribus, which, until the end of the 16th century, was attributed to Sextus Aurelius Victor, in which it is reported that the 'criminal' Carinus was murdered by a tribune whose wife he is said to have raped ("Hic Carinus omnibus se sceleribus inquinavit; Plurimos innoxios fictis criminibus occidit. Matrimonia nobilium corrupit. Condiscipulis quoque, qui eum in auditorio verbi fatigatione taxaverunt, perniciosus fuit. Ad extremum trucidatur eius praecipue tribuni dextera, cuius dicebatur coniugem polluisse" [This Carinus defiled himself with all crimes. He killed many innocent people on the basis of made-up accusations. He destroyed the marriages of nobles. He was also dangerous for his fellow students, who had teased him with mocking remarks in the lecture room. He was slaughtered to death especially by the hand of his tribune, whose wife he was said to have violated] [Incertus Auctor, Epitome de Caesaribus XXXVIII, 7 f., in: Sextus Aurelius Victor, Liber de Caesaribus: Praecedunt Origo gentis Romanae et Liber de viris illustribus urbis Romae, subsequitur Epitome de Caesaribus, ed. Franz Pichlmayr, Stuttgart/Leipzig 1993 (1st ed. 1911), pp. 131-176, here p. 163]. On the question of authorship and the authenticity of the title, see the passages in the editor's introduction in: Sextus Aurelius Victor [Pseudo-Aurélius Victor], Abrégé des Césars, ed. and trans. Michel Festy, Paris 1999, pp. VII-XCIII, here pp. VIII-XXXVIII and pp. XLVIII-L). A similar variant on Carinus' ruthless and excessive life and his related violent death can be found in Aurelius Victor's Liber de Caesaribus. Here, Carinus is murdered in the course of the wars over power in the Roman Empire between him and Diocletian by his own soldiers in revenge for his offences of honor as well as out of fear of the continuance of his rule. ("At Carinus ubi Moesiam contigit, illico Marcum iuxta Diocletiano congressus, dum victos avide premeret, suorum ictu interiit, quod libidine impatiens militarium multas affectabat, quarum infestiores viri iram tamen doloremque in eventum belli distulerant. Quo prosperius cedente metu, ne huiuscemodi ingenium magis magisque victoria insolesceret, sese ulti sunt" [After his invasion of Moesia, Carinus soon engaged at the Margus in a battle with Diocletian; while hastily pursuing the defeated, an assassination attempt of his people caused him death, for, uncontrolled in lust, he pestered the wives of the soldiers, whose angry men, meanwhile, had tried to suppress the anger and pain until the end of the war. When it took a rather fortunate course, however, they feared that a character of this kind would by the victory more and more fall into excess and they took revenge] [Sextus Aurelius Victor, Liber de Caesaribus XXXIX, $11 \mathrm{f}$. (Sextus Aurelius Victor, Liber de Caesaribus/Die römischen Kaiser [Latin-German], ed. and trans. Kirsten Groß-Albenhausen and Manfred Fuhrmann, Zurich/Düsseldorf 1997, p. 114)]; see as well Eutropius, Breviarium IX, 19,1 [Description of Carinus' infamous deeds and announcement of his just punishment] and IX, 20,2 [Diocletian wins, since Carinus, hated on all sides, is betrayed by his own army] [Flavius Eutropius, Breviarium ab urbe condita, ed. Carlo Santini, Leipzig 1979, p. 61 f.]). Frank Kolb points out that the negative depiction of Carinus (as well as of Aper) in the Roman texts may serve a contrasting emphasis of the ruler Diocletian. 
Meanwhile, Numeriano has fallen ill and the army is therefore marching back to Rome when they receive word of Carino's death and are told that the Romans are enthusiastically waiting to proclaim Numeriano emperor. The army immediately does so, but it turns out that Numeriano was already dead. His father-in-law Apro, with his own designs on the throne, had killed him and was transporting his body in a closed sedan under the pretext of a serious illness, as he himself reveals to the messenger Felisardo ("APRO: Enfermo en una litera / le he sacado a la ribera, / donde el campo le recibe, / aunque no le dejo ver, / fingiendo su enfermedad, / que si va a decir verdad ... / [...] / Yo le he muerto, y le he traído / así cubierto y tapado.” vv. 732-740). The corpse is discovered when the soldiers ask to pay tribute to their emperor and to crown him with laurels according to custom. Suspicion is immediately aroused that Numeriano was poisoned by Apro, who, before he gave permission to look inside the sedan chair, strangely emphasized his own merits to the Roman army. In fact, Apro offers himself as the new Caesar, and even announces that he alone would deserve this position, although his murder of Numeriano is finally confirmed by Felisardo and in the end Apro even admits the deed himself. ${ }^{511}$ Diocleciano recalls Camila's prophecy ("agüero") that he would become emperor as soon as he killed a wild boar. The meaning of this prediction, which was initially conceived as a joke, now takes on serious contours for him, for the name Apro is a derivative of the Latin aper, meaning wild boar"512: "DiocL.: si el Cónsul Apro se nombra, / que en nuestra lengua latina, / pues su maldad le transforma, / quiere decir jabalí, / sin duda se cumple ahora / el agüero prometido;” (vv. 894-899). ${ }^{513}$ Diocleciano then stabs

Furthermore, he regards Diocletian involved in the death of his opponent by corrupting Carinus' military officers (Diocletian und die Erste Tetrarchie: Improvisation oder Experiment in der Organisation monarchischer Herrschaft?, Berlin/New York 1987, pp. 11 f.).

511 "MARCELO: Habiendo dado ponzoña / a tu yerno Numeriano, / nos parece injusta cosa. / APRO: ¿Yo, hijos, yo? FeliSARDO: ¿Por qué niegas, / Apro, tu maldad notoria? / Tú me lo dijiste aquí, / y con ponzoña o con toca / quitaste la vida a un hombre / que en las romanas historias, / [ . . ] / no dió tan alta esperanza / de hacer otra vez a Roma / cabeza y reina del mundo; / ¿pues es justo que te pongas / laurel que a tu yerno quitas? / APRO: Eso, soldados, ¿qué importa / si mi valor os agrada, / mis triunfos y mis historias?” (vv. 868-886).

512 APER, APRI (m.): Latin 'wild boar.'

513 The account of the prophecy can also be found in Mexía, who refers to the description in Flavius Vopiscus (cf. the passage in the Historia Augusta: Flavius Vopiscus Syracusius, "Carus et Carinus et Numerianus” [14 f.], in: Scriptores historiae Augustae, ed. Ernst Hohl, Christa Samberger, and Wolfgang Seyfarth, 2 vols., Leipzig 1965, vol. 2, pp. 234-248, here p. 243). But at the same time Mexía distances himself from his source and classifies such 'agüeros' from a Christian perspective as false, even 'harmful' (Mexía, Historia imperial y cesárea [cf. note 500], fols. 127v-128r): When a young soldier in Gaul Diocleciano had met a druidess who provided the soldiers with food. When she complained about Diocleciano's stinginess, he jokingly replied that 
Apro, however, not without legitimizing this act by another augury: Numeriano's ghost had appeared to him in the night and ordered him to avenge his innocent death ("DiocL.: [...] la imagen espantosa / de Numeriano, tu yerno, / convertida en negra sombra, / anoche me apareció, / y me dijo con voz ronca / que de su sangre inocente / diese esta venganza a Roma” vv. 926-932). This element is remarkable in several respects. Diocleciano reports here for the first time, and quite abruptly, his 'knowledge' of Numeriano's violent death. When the soldiers found the corpse of their beloved Caesar, it had been Diocleciano who had pronounced him dead, ${ }^{514}$ while the subsequent accusation that Apro had murdered

he would be more generous when he was emperor. Thereupon the druidess said that he should not be joking about it, because if he killed a wild boar, he would indeed become emperor (“[...] dixole entonces la Driade, pues no lo digays burlando, que quando vos mateys vn apro [como quien dixesse en castellano vn jauali] vos sereys emperador" [fol. 128r a]). Although Diocleciano had laughed at this prophecy, as the years went by and he saw Aurelian, Tacitus, Probus, and finally Carus become emperors, he always killed wild boars if the opportunity arose. When he killed the praetorian prefect and father-in-law of Numeriano, “[...] el qual [...] se llamaua Apro o jauali [...]” (ibid.), he then saw the druidess's prophecy come true (“[...] dixo estonces, Ya se ha cumplido mi aguero muerto he al Apro que me pronosticaua el imperio. Y assi tuuo por cumplida la diuinacion de Driade [...]." [ibid.]). Mexía stresses, however, that he integrated the account of this preannouncement of Diocleciano's rule into his chronicle simply for the sake of light and amusing entertainment ("[...] me parece gracioso, y por sacar vn rato al lector, de cosas graues y pesadas” [fol. 127v b]). Usually, he would not include the predictions and announcements about the rule of the Roman emperors handed down in his sources ("[...] el aguero o annuncio, que cada vno tuuo, de que de emperador emperador, antes que lo fuesse” [fol. 127v b]), because: “[. . . ] las tengo por cosas de grande vanidad [...]” (fol. 127v a). The druidess's 'prophecy' was not to be taken seriously, it was not even a coincidence, Diocleciano had after all killed several wild boars, and only become emperor after killing a man by the name of 'wild boar' ("[...] me parece que es cosa de burla, y no de tomo, porque la adiuinadora no supo lo que se dixo, sino que fue acertamiento suceder, quanto mas que tan poco se puede dezir que acerto, porq[ue] a Diocleciano no le hizieron emperador, quando mato no vno sino muchos jaualies, y al cabo quando lo fue no mato, sino vn hombre, que tenia nombre de Apro, o jauali” [fol. 128r a]). Thus, Mexía sees in the reproduction of such narratives, for "[...] desta manera son todos los agueros que de estos imperios hallo escriptos [...]" (fol. 128r a), not only no benefit, but potential harm to the salvation of the Christian reader's soul: “[...] a ninguna cosa pueden traer prouecho, antes daño en hazer al Christiano mirar en agueros: cosa cierto perniciosissima, y que el demonio lo persuadia a estos infieles" (fol. 128r b).

514 Diocleciano was about to give the laurel branch to Numeriano when he noticed - and he was no less surprised and moved than the other soldiers - that he was addressing his words to a dead man: "DiocL.: Advierte, gran Numeriano, / que todo el mundo te adora; / mira que tus sienes cercan / estas hojas victoriosas, / que aunque parece que tú / honras las sagradas hojas, / muchas frentes han honrado: / no es posible que responda, / porque yo, soldados, pienso / que es muerto. Max.: Su mano toma; / que ella te dirá si es vivo. / DiocL.: Nunca en la frígida zona / carámbanos tan helados / vieron Finmarquia y Libonia; / muerto es el César. 
Numeriano was articulated by Diocleciano's comrades ("MARCELO: No le ha muerto enfermedad, / ipor Júpiter! MAXimiano: Eso es cosa / muy cierta, y que Apro le ha muerto. / CuRIO: En lo que nos dijo ahora / se conoce bien que es Apro, / y que le ha dado ponzoña” vv. 841-846). While Camila's prophecy and Diocleciano's murder of Apro are recorded legends related to Emperor Diocletian's rise to power, ${ }^{515}$ the appearance of Numeriano's ghost before Diocleciano to demand revenge, on the other hand, is an invention of Lope. ${ }^{516}$ This immediately calls to mind the appearance of the ghost in Shakespeare's Hamlet, in which Hamlet's father appears before his son to tell him that he has been murdered and commands Hamlet to avenge his death. In view of the fact that much research has been devoted to identifying Shakespeare's source for this element, ${ }^{517}$ the (mere) presence of this motif in Lo fingido verdadero offers the possibility of broadening the framework of interpretation, also with regard to

CURIO: ¿Qué dices? / DiocL.: Que es muerto, y que la corona / de siempre verdes laureles, / la muerte cipreses torna” (vv. 823-840).

515 See above note 513.

516 It should be mentioned that the transmission of such a dream would be nothing unusual by itself. There are numerous accounts of dreams and visions in the context of Roman emperors' accession to, course, and end of rule. This applies to Diocletian, too, but in the context of his rule only one dream was recorded which was the motivation for his ultimate abdication: In a recurrent dream he was given the order to hand over his power to Galerius (see Gregor Weber, Kaiser, Träume und Visionen in Prinzipat und Spätantike, Stuttgart 2000, pp. $213 \mathrm{ff}$.; the narrative is handed down in the so-called Anonymus post Dionem [fragment 13,6 in: Fragmenta historicorum Graecorum, ed. Karl Müller et al., 5 vols., Paris 1841-1870, vol. 4 (1851), p. 198b], quoted and trans. by Weber, Kaiser, Träume und Visionen, p. 213 with n. 236). To mention more famous examples of dreams in connection with the gaining, preservation or loss of power in Roman imperial history, one could certainly refer to the dream of Constantine (r. 306-337, since 324 sole ruler) before the decisive battle against his opponent Maxentius at the Milvian Bridge in 312, in which the future first 'Christian emperor' was assigned to provide the shields of his soldiers with the 'heavenly sign of God,' the Christian cross (this according to the account, influential for Christian historiography, e.g., in Lactantius, De mortibus persecutorum 44,5 [Lactantius, De mortibus persecutorum/Die Todesarten der Verfolger (LatinGerman), trans. and ed. Alfons Städele, Turnhout 2003, pp. 200/202; English translation: Lactantius, Of the Manner in Which the Persecutors Died, trans. William Fletcher, in: Roberts/ Donaldson/Coxe (eds.), Ante-Nicene Fathers (cf. note 234), vol. 7: Fathers of the Third and Fourth Centuries, Buffalo 1886, pp. 301-322, p. 318]; for Constantine I's dreams and visions in pagan and Christian traditions, see Weber, Kaiser, Träume und Visionen, pp. 274-294, pp. 350-353, pp. 392-398). Moreover, one should mention the dreams and visions in the context of Julius Caesar's death: the dreams of his wife Calpurnia, foreseeing his murder (e.g. Plutarch, Vitae parallelae: Caesar 63,8-11) and the ghosts chasing Caesar's murderer Brutus (e.g. Plutarch, Vitae parallelae: Brutus 36-37,1 and Caesar 69,6-11) (cf. Weber, Kaiser, Träume und Visionen, pp. 432-435, pp. 437 ff.).

517 See above chap. 2, pp. 72 f. with notes 194 and 195. 
a more global view of cultural configurations and processes. The theory of the framework project in which this study was written conceives culture as a virtual network in which cultural material - conceptually as well as materially - is in continuous motion. Once it entered the cultural network, it was there to be used, regardless of its temporal and local origin. ${ }^{518}$ Lope's scene is therefore strong evidence for the thesis that Hamlet's ghost is a motivic material floating in the cultural net. In contrast to the pivotal role played by the ghost in Shakespeare's drama, Lope's use of this 'motivic material' furthers the plot but otherwise has little significance. The mention of Numeriano's ghost demanding revenge for his innocent death serves Diocleciano as additional legitimization to kill Apro before the eyes of the assembled army. He then asks his comrades not to rise up against him, repeating that he had killed a traitor who had deprived them of their good ruler, and adding that if anyone was offended by his actions, he was prepared to bear the consequences. Instead, the soldiers immediately acclaim Diocleciano as their emperor. He orders that the belongings of Apro and Numeriano be distributed among the troops and all leave for Rome.

At the beginning of the second act, Diocleciano, the 'son of a slave' ("DiocL.: [...] soy hijo de un esclavo;” v. 909) was now emperor and had been received jubilantly in Rome. He promises generous payments to the army, a feast for the Senate, and announces public festivities with gladiator fights and wild animals. He also elevates his friend Maximiano to be emperor with him. ${ }^{519}$ When Camila comes before him and asks him to keep the promise he had made her, he

518 See Joachim Küpper, The Cultural Net: Early Modern Drama as a Paradigm, Berlin/Boston 2018.

519 Vv. 1045-1108 (esp.: “César te hago; no ignores / la paz de nuestros estados; / que como fuimos soldados / seremos Emperadores. / Cuando partimos el pan / quitado a los enemigos, / éramos buenos amigos; / hoy que este Imperio nos dan / los benignísimos cielos, / pártamosle entre los dos[,] / [. . .]. / Dadme un laurel” vv. 1073-1085). Diocletian appointed his companion Maximian (M. Aurelius Valerius Maximianus) as Caesar probably at the end of 285 and as second Augustus on April 1, 286. In 293, he extended this dyarchy to the tetrarchic system of rule: These two Augusti - Diocletian ruled the eastern part of the empire, Maximian the western part - were each joined by a Caesar as junior emperor, who was adopted by the senior emperor and destined to succeed him. Constantius (I., 'Chlorus,' Flavius Valerius Constantius) was elevated to Caesar for the West, he was also married to Theodora, Maximian's stepdaughter; Galerius (C. Galerius Valerius Maximianus) was appointed junior emperor of the East and married Diocletian's daughter Valeria. The first Tetrarchy ended with the abdication of Diocletian and Maximian in 305, Constantius and Galerius ascended to Augusti and in turn were given new Caesares. (Cf. Demandt, Die Spätantike [cf. note 500], pp. 58 f., p. 72; Kolb, Diocletian und die Erste Tetrarchie [cf. note 510], pp. 22-87; Andresen/Erbse et al. [eds.], Lexikon der Alten Welt [cf. note 500], cols. 745 f. [Diocletian], col. 1872 [Maximian]; Kuhoff, Diokletian und die Epoche der Tetrarchie [cf. note 500], pp. 28-35, pp. 107-135, pp. 297-326). 
complies with her request to have free access to the imperial chambers and to always be near him. In the same way that Camila's prediction that Diocleciano would become emperor as soon as he kills a wild boar ultimately proved true after he had killed the consul Apro, this statement, originally conceived as a burla, also becomes verdad; play has turned serious. ${ }^{520}$ It is important to point out here that the turn from play to seriousness thus constitutes a structural element in the world of the play. This model of a 'structured reality' can be seen as standing in opposition to a reality dominated by chaos and coincidence. Long before it is mentioned in the play, this element refers to the idea of the single God directing the whole world down to the smallest detail. ${ }^{521}$

Shortly afterwards, Ginés appears before the emperor. Diocleciano commissions him to perform a "gentil comedia" (v. 1206) that same day, during the feast for the Senate. The subsequent discussion over the appropriate play to choose contains several allusions to poetological debates taken place during the time $L o$ fingido verdadero was written. For example, when Ginés suggests works by the two most prominent representatives of Roman comedy, Terence and Plautus (Andria and Miles Gloriosus, respectively), Diocleciano replies: "Dame una nueva fábula que tenga / más invención, aunque carezca de arte; / que tengo gusto de español en esto, / y como me le dé lo verosímil, / nunca reparo tanto en los preceptos, / antes me cansa su rigor, y he visto / que los que miran en guardar el arte, / nunca del natural alcanzan parte" (vv. 1210-1217). When talking about what tragedies would be relevant, Camila interjects that performing a tragedy would be a bad omen. Diocleciano ultimately instructs Ginés to choose whatever play ('comedia') he wants, and the latter chooses one of his own. ${ }^{522}$ After

520 The passage as a whole: vv. 1110-1190. Camila begins her speech with the statement "Las cosas que ordena el cielo / en sus secretos divinos, / van por tan raros caminos, / que no los entiende el suelo" (vv. 1110-1114), and describes once more what has happened explicitly as 'burlas verdaderas': “[E]n el Asia [...] Diocleciano, / [...] / [v]ivía en tanta pobreza, /que si algún pan me tomaba, / la paga que no me daba, / con risa y con gentileza / decía que remitía / cuando fuese Emperador; / yo [...] / por burla le respondía / que vendría a serlo cuando / diese muerte a un jabalí; / dió muerte al Cónsul, y así / llegó a ser César burlando. / Ya que he visto verdaderas / a sus burlas y a las mías[,] / vengo a ver si en tales días / paga las deudas primeras" (vv. 1117-1136; my italics).

521 Regarding this, see, e.g., Mt 1,29 ("Nonne duo passeres asse veneunt? et unus ex illis non cadet super terram sine Patre vestro"/“Are not two sparrows sold for a farthing? and one of them shall not fall on the ground without your Father').

522 "Haré la mía. / Porque si acaso no te diere gusto / no pierda la opinión ningún poeta" (vv. 1263-1265). As the subsequent monologue (vv. 1292-1351), his conversation with Pinabelo (vv. 1352-1433), and especially the performance itself (vv. 1618-2098) show, the fact that the piece to be performed is 'his comedia' ('haré la mía') does not only refer to the 
Diocleciano talks about Ginés' reputation as an actor who is famous for his portrayal of falling in love (“[...] imitas con extremo / un rey, un español, un persa, un árabe, / un capitán, un cónsul; mas [...] todo / lo vences cuando imitas un amante" vv. 1266-1269), Ginés explains what he considers to be the essentials of acting: acting was imitation ("El imitar es ser representante;" v. 1270), but to be effective it must contain a kernel of truth. To convincingly portray love's passions one must feel them, just as to write a convincing poem about love, the poet must be in love himself:

\author{
[...] el representante, si no siente \\ las pasiones de amor, es imposible \\ que pueda [...] representarlas; \\ una ausencia, unos celos, un agravio, \\ un desdén riguroso y otras cosas \\ que son de amor tiernísimos efectos, \\ harálos, si los siente, tiernamente; \\ mas no los sabrá hacer si no los siente.
}

(vv. 1276-1283)

The subsequent monologue on love (vv. 1292-1351), elaborates further on this aspect. Love itself, or rather 'its fire,' is the reason behind his outstanding acting and his reputation as an 'extreme' performance as lover: "Contento estarás, amor, / de hacer en mí con tu llama / más levantada mi fama / cuanto es mayor tu rigor. / Hasta el magno Emperador / llega de que represento / tu fuego, tu sentimiento / con tanto extremo [...]" (vv. 1292-1299).

The blurring of the boundaries between seeming and being and the difficulty of distinguishing between fiction and reality, play and seriousness, to which the subsequent events are subjected, is hinted at here: "[. . .] imito lo que siento; / pero en tanta propiedad / no me parece razón / que llamen imitación / lo que es la misma verdad;" (vv. 1301-1305). His will (mi voluntad) was the play (comedia), his intellect (entendimiento) the poet of the story (fábula), all his mad senses (locos sentidos), through the representation of similar figures (figuras semejantes), had become actors (representantes) of his own surrendered emotions (afectos rendidos), he continues (vv. 1306-1315). The passion (of love) dominates him in such a way that he ignores good advice and instead follows those that plunge him into ruin ("rompo los consejos sanos, / y los que me matan sigo" vv. 1336 f.), furthermore, he considers himself a person in whom live 'a thousand houses of madmen' (mil casas juntas de locos) (v. 1339). The

fact of authorship, but has also a content-related dimension: the comedia written by Ginés and his own reality of life are closely interlinked. 
monologue's final verses refer to the overlapping of reality and play and the potential effect of fiction on reality. If the author - in this case Ginés himself - did not proceed with care, the comedia de amor would be in danger of coming to a bad end, that is, not ending with the usual obligatory marriage (“[...] aunque es comedia de amor, / si el autor no la remedia, / no tendrá fin de comedia, / pues no ha de parar en bodas, / porque las figuras todas / las hace el dolor tragedia” vv. 1346-1351). The conversation between Ginés and Pinabelo, another actor, illuminates the context of the implied dilemma of love, revealing that Ginés is unhappily in love with the actress Marcela, who is in a relationship with Octavio, also an actor of the ensemble. Ginés does not want to fire his rival both because Octavio is one of his best actors and has the leading role in the current play, and because he would lose Marcela as well, who, in her despair over the loss of Octavio would lose her pleasure in acting. He further says that even though he had her father's blessing, he would not take that course. Instead, the lovesick Ginés plans to take advantage of the upcoming play to make Octavio jealous, with numerous moments in which he and Marcela embrace. Thus the "comedia [...] / [...] amorosa” will become a "[comedia] celosa” (vv. 1404 ff.) that strains the bond between the two lovers. ${ }^{523}$

After the spectators (the two emperors Diocleciano and Maximiano, the two senators Léntulo and Patricio, and Camila) take their seats, the first 'play within the play' of Lo fingido verdadero follows the conventions of Spanish comedia by beginning with a loa. Ginés here compares ${ }^{524}$ his own efforts with those of the poet Tebano. In order to pay his respects to Alexander, who had arrived in Athens, the poet was kneeling down before the ruler. In doing so he dropped his gloves, which he had, according to custom, taken off beforehand, and upon picking them up mistakenly thought they belonged to Alexander and handed

523 "GINÉs: Compúsela con cautela / por darle [a Marcela] tantos abrazos, / cuantas prisiones y lazos / pone el alma que desvela; / aquel paso de furioso / le hice por tratar mal / a Octavio." In response to that then Pinabelo says assessingly: "No tiene igual / tu pensamiento celoso" (vv. 1410-1417).

524 Ginés' speech is embedded in two pieces of music. The first (vv. 1466-1489) is a jubilant song on Rome and the new Emperor Diocleciano (marking his triumphant entry in Rome and his accession to the throne, legitimized solely by his virtue and deeds). The second (vv. 1588-1617) praises the female beauty of "Lucinda" (v. 1588) or the grace of Camila, respectively, using the popular antithetical parallelism 'bien puede ser / no puede ser' and Petrarchist metaphors (e.g. "Que su boca celestial / no sea el mismo coral, / bien puede ser; / mas que no exceda la rosa / en ser roja y olorosa, / no puede ser;” vv. 1594-1599). 'Camila Lucinda' is the name of the lover to whom Lope de Vega dedicated numerous sonnets, which are believed to have been intended for the actress Micaela de Luján (cf. the editor's note, p. 109; as well as Canning, "Lo fingido verdadero as Metaplay" [cf. note 494], p. 111). 
them to him. Ginés describes the 'senses and faculties of the soul' as 'the soul's gloves.' He lay these gloves before Diocleciano, thus emphasizing that his performance shows the pure motions of his soul, undisguised by the rational faculties. $^{525}$ The response of the audience to the loa is so enthusiastic that Diocleciano presents him with a ring as a token of his appreciation.

The comedia then beings, with Ginés playing the galán Rufino, Marcela the dama Fabia. The first scene opens with Fabia's gruff rejection of Rufino's love (“[...] más que tú en quererme, / en aborrecerte siento” vv. 1622 f.). Only a few verses later, however, the dividing line between stage and real life is already crossed: Ginés does not address Marcela with her role name, but with her real name, when he accuses her of the affection she has for Octavio, who also bears the name Octavio in the play ("Bien sé, Marcela, que nace / el hacerme aqueste agravio / de que quieres bien a Octavio; / Octavio te satisface, / Octavio te agrada, ingrata; / por él me dejas a mí” vv. 1646-1651). Marcela breaks character (later: “Advierte que me has turbado, / volvamos al paso" vv. 1666 f.) and asks Ginés, whom she calls by his real name, whether he was still acting ("Ginés, ¿representas?” vv. 1652) and why he did not address her by her role name. The reason, he answers, was "Por hablarte / de veras, por obligarte / a que tu desdén se duela / de aqueste mi loco amor” (vv. 1655-1658). In response to Marcela's question as to what she should answer, Ginés says that the best would be to return his love. Marcela's repy, "Esto no está en la comedia" (v. 1662), shows that she only wanted to know how she was to react in the context of the play and the appropriate continuation of the performance, whereas Ginés was alluding to 'real life.' This scene not only confuses Ginés' fellow actors, but the imperial audience as well. While Maximiano and Léntulo consider what has just happened on stage to be a simple lapse, attributed to nervousness, Diocleciano interprets the situation as part of the play and a sign of great acting: "Mas pienso que es artificio / deste gran representante, / porque turbarse un amante / fue siempre el mayor indicio" (vv. 1678-1681). Then the actor Fabricio appears in the role of old Tebandro, Fabia's father. Rufino, not without referring to his pedigree as the son of a consul, ${ }^{526}$ asks him for his daughter's hand. Tebandro finally promises that

525 “[D]e toda el alma quité / los sentidos y potencias, / que se calza como guantes / según se ajustan en ellas, / y púselos, no en las manos, / aunque manos son la lengua, /que la lengua son las manos / del alma, pues que con ellas / se hace lo que dispone /y se obra lo que ordena. / [ . . ] / se me cayeron [. . .] / todas las razones della; / [. . ] / . . .] si en la presencia vuestra / por respeto se han caído / del alma las tres potencias, / no merezco ser culpado[,] / [...]" (vv. 1540-1572).

526 Rufino is “[...] hijo de Patricio, / que mereció la consular corona” (vv. 1716 f.). It is worth noting that this, albeit in a very subtle way, establishes a link between the levels of the inner 
Fabia will become his wife, but asks Ginés/Rufino again to tell him his name, Ginés answers "Rufino" (v. 1737). ${ }^{527}$ Meanwhile, the servants Octavio and Pinabelo (also in his case the name of role and actor are identical) have entered the stage and watch Rufino hugging Fabia. What Octavio cannot see however, is that this gesture of affection was entirely one-sided. Rufino had asked Tebandro for permission to hold his daughter's hand as a sign of his consent to the wedding. Fabia had at first refused (her comment: “¡Qué notable desatino!” v. 1741), but then followed her father's order to comply with this wish ("Obedecerte / es justo.”, then Rufino emphatically: “Ahora amor mi vida ofrezca / con esta mano y brazos a la muerte” vv. 1743-1745). In the following scene Rufino and Tebandro are off stage, having gone to visit Rufino's father, and the lovers Octavio and Fabia meet. Their encounter, however, is at first completely dominated by Octavio’s intense jealousy. Rufino had left the stage saying: “¿Qué habrá que el amor no pueda?” (v. 1752) so Octavio remarks: “¿Qué habrá que no puedan celos?” (v. 1753) and then calls Fabia “ingrata” (v. 1755) and makes use of a misogynous topos of women's inconstancy: “¡Ay Fabia, que eres mujer, / y eres la misma mudanza!” before finally threatening her: "La lengua injusta reporta, / que incitarás mi paciencia / a que te quite la vida” (vv. 1788-1790). Fabia asserts her innocence: “[. . . ] no dando ocasión yo, / Rufino en mi casa entró, / a quien he dado forzada / la mano por obediencia / de mi padre; [...]” (vv. 1782-1787) and calls Octavio a "loco amante" (v. 1792) dominated by "furia" (v. 1793). She asks Pinabelo, who witnesses the dispute, for advice. He reminds them of their mutual deep affection, names the possibility of running off together by ship to Octavio's homeland in order to escape the seemingly hopeless situation of their unhappy love and offers to help them in this undertaking. However, as the audience learns from an aside, this offer is insincerely meant, since Pinabelo wants Fabia for himself ("PiNABELO: Hoy, amor cruel, / fuiste conmigo piadoso; / no la verá más Octavio, / aunque a mi lealtad agravio" vv. 1837-1840). ${ }^{528}$ When Fabia and

play and the stage audience, as among those attending the performance is a senator named Patricio. In Rotrou's play, however, this type of linking will be highly complex, as Maximin is both spectator and character of the play being performed.

527 Given that Fabricio is Marcela's father in reality as well as on stage, it could also be an improvised addition by Fabricio due to the preceding confusions, in order to make sure whether Ginés speaks in his role as Rufino or expresses his desire 'seriously'; however, this remains pure speculation.

528 Regarding Pinabelo's intrigue (Fabia's abduction), which is apparently grounded in the inner play, see the comment and interpretation by Léntulo: "Ahora quiere el criado / ser traidor a su señor; / que Octavio, al padre traidor, / viene a quedar engañado. / De suerte que aquel Rufino / y este Octavio han de quedar / sin Fabia, y la ha de gozar / su esclavo” (vv. 1855-1861). 
Octavio decide to take Pinabelo's advice and run away together the border between fiction and reality is further blurred: Marcela and Octavio 'fall out of their roles.' They wish nothing more than for the comedia to become reality (" $\mathrm{iAy}$ cielo, si verdad fuera / la comedia!” vv. 1843 f.). That Marcela and Octavio are speaking in earnest, becomes clear when Marcela mentions Ginés and Octavio addresses her by her real name ("MARCELA: Tan perdida estoy, / que quisiera que a Ginés / le hiciéramos este tiro. / OCTAVIO: Tu lealtad, Marcela, admiro” vv. 1845-1848). This ambivalence between acting and reality, between fingido and verdadero is remarked upon by inner spectator Diocleciano, who notes: "Sospecho que representan / estos su misma verdad” (vv. 1850 f.). A little later, the servant Celio tells Tebandro and Rufino, who had returned from their visit to Rufino's father, that he himself had been at the port and seen Fabia and Octavio boarding a ship to run away together to Spain. This puts Rufino in a rage and he launches into a passionate speech (in the words of the servant Celio: "No des, Rufino, la rienda / a tu amor con tanto exceso, / que es caballo desbocado" vv. 1955-1957). The spectators are deeply impressed by Ginés' acting talent, which has lived up to its reputation.

It is now that the actual theme of Lope's play comes into the fore. The senators remark to Diocleciano that Ginés' performance of a frenzied lover was nothing compared to his portrayal of a Christian. Diocleciano immediately declares that Ginés should demonstrate this the very next day: "Mañana, por hacer burla / destos que a Marte y a Venus, / a Júpiter y a Mercurio, / niegan el debido incienso, / quiero que Ginés me haga / y represente uno dellos, / por al vivo un cristiano / firme entre tantos tormentos" (vv. 1975-1982).

As it turns out, something is wrong, because Rufino's monologue should have ended long ago and Tebandro should have returned with Octavio and Fabia by now. Ginés assumes that the actors, who failed to appear on cue must still be in the dressing room and sends for them. In the meantime, he decides to fill in the time by further improvising his speech on jealousy. ${ }^{529}$ This renewed intermeshing of the levels of stage life and real life, the associated doubts about distinguishing with certainty what is real and what is acting, characterize the "play within the play' until its very end. Fabricio appears and announces that Octavio and Marcela (he does not say Octavio and Fabia) had disappeared and that the play had become truth ("[. . .] Octavio / hizo verdad este agravio[.] / [. . ] / [E]l mismo paso que hacía / Fabia, o Marcela, hija mía, / a quien amaba el autor, / han hecho tan

529 "GINÉs: Celio, ¿qué te digo, Celio? / Di que salgan; que ya he dicho / de improviso todo esto; / mira que se acaba aquí / este romance. CELIO: Ya veo / que hablas sin papel. / GINÉs: Sin duda se están vistiendo; / repetir quiero otra vez / aquellos primeros versos;” (vv. 2000-2008). 
verdadero, / que han salido del Palacio, / y [...] / [. . . n[o] hay un hombre / que diga por dónde van” vv. 2017-2033). When, in response to this, Ginés asks Diocleciano to let Octavio, the 'traitor,' be persecuted, because otherwise it would be impossible to tell the end of the story, ${ }^{530}$ it is still not clear to the emperor whether this is part of the fictional play or not, or whether it was a new way of acting or dramatic fashion to involve the audience in the improvisation and turn the spectators themselves into actors ("DiocL.: ¿Es esto representar / y a la invención convenible, / o quieres mostrar, Ginés, / que con burlas semejantes / nos haces representantes?” vv. 2042-2046). Thus, the suspension of the border between fiction and reality reaches a new level. Ginés disabuses Diocleciano of his assumption and answers that it was certain that Octavio was in love with Marcela and that the two had indeed fled together, and thus made use of his intended trick to have life imitate theater and inflicted on him the engaño that he himself had written. ${ }^{531}$ Diocleciano, however, is not convinced of Ginés' sincerity and reacts more and more indignantly to the confusion: “¡Por Júpiter, que sospecho, / y no sé si lo rehuse, / que quieres que represente! / ¿Hablas de veras o no?" (vv. 2054-2057). Thereupon, Pinabelo enters and announces that Octavio has returned. Fabricio instantly points out Ginés' great acting to the emperor, and Ginés himself subsequently expresses his gratitude for the emperor's participation in the play. Diocleciano, now in a good mood, interprets everything as a successful burla. Since, however, he himself had taken on a part in the play and had been an actor himself, he declared that he would not pay for today's performance, which was now declared to be over. For the next day, however, he commanded the performance of a different play, in which Ginés should play the Christian: “[...] quiero ver / cómo finges un Cristiano" (vv. 2076 f.), to which Ginés himself replies that that is indeed what he did best: "Verás, señor soberano, / lo mejor que suelo hacer" (vv. 2078). ${ }^{532}$

530 “[...] señor, / manda seguir al traidor / que se lleva esa mujer, / sin la cual es imposible / poder la historia acabar” (vv. 2037-2041).

531 "Ginés: No, señor; muy cierto es / que Octavio amaba a Marcela, / y porque como a su autor / me mostró su padre amor, / trazaron esta cautela; / de suerte que yo compuse / el engaño que me han hecho" (vv. 2047-2053).

532 "FABRICIO: Mira, gran señor, si ha sido / Ginés buen representante. / GinÉs: Yo quiero de aquí adelante / darte, gran señor, partido, / pues tan bien me has ayudado / para proseguir mi intento. / DiocL.: De la burla estoy contento, / y pues he representado / mi figura en vuestra historia, / no es razón que el tesorero / os pague. Ginés: Por compañero / igual, lo tendré por gloria. / DiocL.: Pues no paséis adelante; / pero mañana volved / para que os haga merced, / pues hoy soy representante; / y advierte que quiero ver / cómo finges un cristiano" (vv. 2060-2077). 
While the spectators are still in the midst of leaving, Ginés asks Pinabelo whether he was telling the truth before and Marcela had indeed returned, or whether his message about Octavio's return was merely to diffuse the anger of the emperor. ("Saber, Pinabel, deseo / si es cierto el volver Marcela, / o fue porque no se enoje / el Emperador” vv. 2083-2086). Obviously, even Ginés was struggling to keep the two realms of fiction and fact separate, and therefore could not correctly identify how to understand Pinabelo's words. Was it the 'character' Octavio who had returned, or the actor? Pinabelo tells him that in fact no, Octavio had not returned and that Marcela and Octavio had actually run off together. Ironically, however, choosing the same mode of transport as the lovers in the play: "GinÉs: Luego mi agravio / es cierto. PINABELO: Y que ella [Marcela] y Octavio / se van, Ginés, a embarcar” (vv. 2089-2091). When Ginés then articulates the pain of his jealousy, his 'burning desire' for Marcela in the final verses of the second act, he consciously repeats parts of his character's speech. The emotions he portrayed in the role of Rufino when he learned of his bride Fabia's escape now correspond to his own, the pain and anger are real ("mi tormento es cierto" v. 2095), fiction has become reality. ${ }^{533}$ His immediate reaction is to exclaim: “¡Oh, terrible desconcierto!” (v. 2092). On the one hand, this may refer to his inner turmoil - after all, his love has run away with his rival - on the other hand, it may refer to his plan that has been turned on its head and thus 'foiled.' It had, after all, been his intention to use the comedia to manipulate the real relationships to his advantage by fueling Octavio's jealousy and regaining Marcela's affection.

This sentence, however, also expresses a characteristic element of this second act, Ginés' comedia de amor - the first 'play within the play' in Lope's play presents a well-staged 'desconcierto,' which problematizes the 'correct classification' of what is being perceived as 'real' or 'fictitious' and destabilizes the boundary between fingido and verdadero. To recap: Ginés, who is in love with Marcela, plays Rufino, who desires Fabia, who is played by Marcela; Octavio, who bears the same name in the play, is the rival of both Ginés (in the inner reality)/Rufino (in the inner play); Marcela (in reality) as well as Fabia (in fiction) love Octavio; Marcela's father Fabricio plays Tebandro, Fabia's

533 "Quiero volver a decir, / pues que mi tormento es cierto, / que la [here: Marcela] tengan los cielos, / que mal la alcanzarán mis pensamientos / si camina por agua y yo por fuego” (vv. 2094-2098). These are verses that Ginés speaks twice in his stage role as Rufino. In Rufino's jealousy monologue applauded by the audience (vv. 1923-1954, here v. 1952 ff.: "pero tenedla, cielos, / que mal la [here: Fabia] alcanzarán mis pensamientos / si camina por agua y yo por fuego") and then once again as part of his improvisation to bridge the pause caused by the missing return of his fellow actors to the stage (vv. $2009 \mathrm{ff}$.). 
father. Even though the viewer/reader, in contrast to the audience on stage, knows from the beginning about the relationships between the actors and the intention of the play's author, this knowledge does not necessarily result in being able to determine clearly between fiction and reality in the context of the play and the 'play within the play.' This pre-knowledge often actually complicates matters. The permeability of fiction and reality (in the conversation between Ginés/Rufino and Marcela/Fabia, the flight of Octavio/Fabia or Octavio/ Marcela, etc.) causes those moments in the 'play within the play' not clearly marked as 'reality' (as, for example, when the actors real names are used) to, at least potentially, be 'under the suspicion' of also being 'true' and not belonging to the play. The blurring of the boundaries between fiction and reality in this scene includes the experience of the (imperial) audience, who are not only led to doubt the status of what they are seeing on the stage before them, (thereby manifesting the problematic distinguishability of 'real' and 'fake,' even in a framework that is clearly identified as 'fictitious') but are also subject to the 'extension of the stage' to the audience space ${ }^{534}$ : 'De la burla estoy contento, / [...] he representado / mi figura en vuestra historia[.]' and '[. . . hoy soy representante;', Diocleciano finally states, when he terminates the performance. Shortly before, Pinabelo had announced Octavio's return on stage. Unlike the internal audience, the viewer/reader knows at the end of the second act that this was not true, but, as Barbara Simerka puts it: "Here, the spectators can be confident about their own knowledge of the truth, but also see how easily truth can be manipulated." 535

In the beginning of the third jornada Diocleciano and Camila confess their love for each other. Diocleciano is then informed about the fieras ('beasts/wild creatures') who have been brought to Rome in honor of the festivities. ${ }^{536}$

534 See also Fischer's classification of the first play within the play: “Act II of Lope's tragicomedia is mainly concerned with the staging of a play-within-a-play that takes the form of an improvisation by Ginés' acting troupe" ("Dramatization of the Theatrical Experience" [cf. note 494], p. 161).

535 Simerka, "Metatheater and Skepticism" (cf. note 2), pp. 50-73, here p. 67.

536 Taking up nearly a hundred lines (vv. 2139-2236), the enumeration of the 'monsters' brought from all over the world includes real animals endowed with marvelous qualities, such as lion, bear, wild boar, panther, tiger, monkey, rhinoceros, crocodile etc., as well as mythical creatures, such as Pegasus (“un Pegaso” [v. 2203]), "un cinoprosopo” (v. 2167) - a creature with a dog’s head and human body -, "un onocentauro ['donkey centaur'] / con rostro de hombre, y el cuerpo / de una bestia [...]” (vv. $2213 \mathrm{ff}$.) etc. This list of 'mythical creatures' was based primarily on Pliny's Naturalis historia, for this and other sources used by Lope for this material (especially Antonio de Torquemada, El jardín de flores curiosas [1570] and Pedro Mexía, Silva de varia lección [1540]), see E. di Pinto, "La tradición animalística clásica en Lo fingido verdadero" (cf. note 494). For di Pinto, 
Camila notes that the wildest animal, however, that by far surpasses all the ones mentioned in cruelty, was love. ${ }^{537}$ She also declares that she was unwilling to attend the spectacles if prisoners were to be thrown to the beasts, because she did not want to see them being killed, for they were human beings and she respected all human beings. Thereupon, Diocleciano decides to

the monologue is 'enumeratio' (“[...] las referencias animalísticas no tienen una importancia simbólica; [...] tenemos una serie de animales [...] que forman parte de una mera enumeratio [...]" [p. 200]), and it had been able to appeal to the 'ordinary people' and the learned audiences alike (the former had been amazed, the latter had been demonstrated their versatile education and they could have found pleasure in tracing the references transported with the animals). It was to be understood as a scenery of words and was an indication for the metatheatrical dimension of Lope's play, because: “[...] [L]os espectadores llegan a ver la escena descrita [. . . porque 'quieren' creer en lo que [se] describe [...] implicándose en el juego de participar activamente en la representación" (cf. p. 212, quote: ibid.). However, the passage certainly also suggests an allegorical reading. Nolting-Hauff points to the presence of 'traditional emblematic motifs' ("traditionelle [n] emblematische[n] Motive"), which, according to her interpretation, 'indicate that the focus here is on Diocleciano's rise to power and his transformation into a tyrant' (“[...] darauf hin [deuten], daß es hier [...] um den Aufstieg Dioclecianos und seine Wandlung zum Tyrannen geht") (see "Lo fingido verdadero" [cf. note 491], p. 79 with notes 31-33 [p. 87], quote: p. 79). I would like to mention two examples, cited as well by Nolting-Hauff: "un pathaga semejante / [.. . ] / al cocodrilo de Egypto, / que llora y que mata luego;” (vv. 2209-2212) and “[. . ] un dragón que, asido al pecho / de un elefante, le mata, / aunque no se alaba dello, / porque cayendo sobre él, / mata al que le mata, muerto[;]" (vv. 2228-2232). The emblematic meaning of the crocodile weeping for its victims is 'false friendship' ("falsche Freundschaft" [see Arthur Henkel/Albrecht Schöne (eds.), Emblemata: Handbuch zur Sinnbildkunst des XVI. und XVII. Jahrhunderts, Stuttgart 1967, cols. $672 \mathrm{f}$.]). The emblematic meaning of the dragon who is dying himself when he kills an elephant is 'deadly victory' and 'punished tyranny' (“tödlicher Sieg," "bestrafte Tyrannei” [cols. $411 \mathrm{ff}$ ]). Nolting-Hauff points out that 'the other animal names, too, seem to refer predominantly to the tyrant's wrath and ingratitude' ("Die übrigen Tiernamen scheinen ebenfalls vorwiegend auf Zorn und Undankbarkeit des Tyrannen zu verweisen”) (“Lo fingido verdadero,” p. 79, with note 32 and reference to Henkel/Schöne, Emblemata and the index printed there regarding Filippo Picinelli, Mundus Symbolicus [1681], cols. 2113-2196, here col. 2120 [boar], col. 2160 [lynx], col. 2125 [bison], col. 2190 [tiger], col. 2178 [rhinoceros]).

537 The 'fiera amor' would not even fear death in its pursuit of pleasure, and, furthermore, which was far more serious, it would inflict harm to the soul ("ninguna [fiera] viene tan fuerte, / porque no teme a la muerte / adonde su gusto espera. / Ellas pueden hacer daño / en las vidas; pero amor / en las almas, que es rigor / más estupendo y extraño" [the passage in total vv. 2237-2252, here vv. 2245-2252]). - Also the description of love as the cruelest and invincible fiera is an allusion to traditional emblems: see Henkel/ Schöne (eds.), Emblemata (cf. note 536), cols. 385 f. ("gezähmte Löwen vor dem Wagen Amors," "gezähmter Löwe, auf dem Amor reitet" - "Macht der Liebe" [tamed lions hitched to Cupid's carriage; a tamed lion on whom Cupid is riding - the power of love]). The reference to this in Nolting-Hauff, " $L o$ fingido verdadero" (cf. note 491), p. 87, note 31. 
renounce this cruelty ("No se trate más / esta fiesta de las fieras, / que no es fiesta la crueldad: / véalas por novedad / Roma” vv. 2268-2272). This cancelation (of the accepted Roman practice of killing people for the purpose of entertainment) in the name of 'love' foreshadows the shift of the empire, slightly later in history, towards Christian humanitarian values. Ginés is then called and Diocleciano inquires into Marcela and Octavio's whereabouts. Ginés reports that Marcela's father had found them, they were married, and he had forgiven them and taken them back into the acting company, adding that he did not even feel jealous anymore. Diocleciano notes that this was a characteristic feature of poets, and repeats his commission: "La imitación / del cristiano bautizado, / porque es un extremo en ti. / [. . ] / pon el teatro, y prevén / lo necesario;" (vv. 2312-2318). When, after that, Ginés is alone, he expresses, in the form of a sonnet monologue and using traditional metaphors of Baroque love poetry, his realization of the duplicity of love and his own hitherto false way of loving. Love had pushed him into such misfortune during his youth that he had thought that in the 'sea of its deceptions' ("por el mar de sus engaños" v. 2327) he would not reach the port, but rather find his grave. However, although this fire (of love) lasted even in the ashes, he already felt its injuries far less strongly. He had loved jealously and now sought to distance himself from this understanding of love by classifying what he had previously called love as locura (madness): "amé con celos, mas con desengaños / no pienso que es amor, sino locura” (vv. 2331 f.). He continues: while living in deception, an offended lover's sorrows might well remain in the faith of feigned, false love. It did not matter what the offended wished, because those who love jealously had already reached the beginning of oblivion. ${ }^{538}$ It should be noted at this point that, in light of what is to happen later in the third act, Ginés' abandonment of his previous love, which was marred by jealousy, is based on a shift or transition, of which the protagonist himself is not yet aware; namely, a turning away from worldly, deceptive, false, destructive love in the sense of desire, towards, eventually, 'true' Christian love. In the subsequent conversation between Ginés and Marcela, the events of the past day, specifically the amor fingido (v. 2341) are discussed. To Ginés' question as to whether her love for him had been

538 The sonnet in its entirety: "Amor me puso en tanta desventura / la verde primavera de mis años, / que pensé por el mar de sus engaños / en vez del puerto hallar la sepultura. / Y aunque este fuego en las cenizas dura, / ya con menos rigor siento sus daños; / amé con celos, mas con desengaños / no pienso que es amor, sino locura. / Bien pueden mientras viven engañados / conservarse en la fe de amor fingido, / de un ofendido amante los cuidados. / ¿Y qué importa que quiera el ofendido? / Que quien ama con celos declarados, / ya llega a los principios del olvido" (vv. 2325-2338). 
'fictitious' Marcela answers that it was, but her love for the man she truly loved is sincere and faithful. ${ }^{539}$ Here, once again, the overlap between fiction and reality that Ginés had instigated and which then slipped out of his control, becomes apparent. Marcela draws Ginés' attention to his own guilt, for it was only through the comedia he had written that she had become completely sure of her love for Octavio. Ginés replies that his intention had been quite different, but that he did not bear grudges and wished her all the best. ${ }^{540}$ The two then engage in a somewhat flirtatious banter ${ }^{541}$ that is immediately categorized by Ginés as 'play,' i.e. false, and which will serve him as a useful source for the scene of a future play ("A tus razones advierto: / dellas quiero aprovecharme / para escribir en un paso / esto que contigo paso, / pues parece que los dos / representamos" vv. 2377-2382; my italics). Octavio, now Marcela's husband, comes along and is obviously jealous. ${ }^{542}$ From his perspective, fictitious love, whether in the form of Marcela's flirting with Ginés or her acting on stage, and real love are indistinguishable, both appearing to him as true ("Celos son todos, quimeras; / haz, Marcela, lo que te digo, / que aun las burlas, no las veras / que representa [Ginés] contigo, / me parecen verdaderas” vv. 2404-2408).

Ginés, now alone, prepares for his stage role as a Christian martyr (“[...] bueno será / pensar en esta figura / [ . .]; / [ . .] un cristiano [. . ] / que firme en su ley está. / ¿Cómo haré yo que parezca / que soy el mismo cristiano / cuando al tormento me ofrezca? / ¿Con qué acción, qué rostro y mano / en que alabanza merezca?” vv. 2414-2423). He rehearses for his role as a Christian who

539 Vv. 2344-2348.

540 "MARCELA: [.. .] tú, que compusiste / la comedia en que me diste / a Fabia, que a Octavio amó, / y el camino me enseñó, / luego la culpa tuviste. / GinÉs: Compuse que te ausentabas / de tu padre con Octavio, / a quien con extremo amabas, / para sentir el agravio / con que entonces me tratabas, / mas no para que te fueses. / MARCELA: Pues yo lo entendí mejor. / GinÉs: Que muy contenta estuvieses / querría” (vv. 2354-2367). Besides his intention to make his competitor Octavio jealous with the comedia, Ginés also expresses here the wish, through Marcela's temporary disappearance that he wrote into his play, to be able to feel even more clearly his own pain, which he really feels and experiences on stage, over this hurt. The set of issues of fingido amor does not only include the problem of potentially false, feigned love on an interpersonal level due to the complicated interweaving of stage role and 'real' life of the lovers or rejected lovers, but also involves the level of play/fiction, insomuch as love and emotions are 'faked' for the audience.

541 "GinÉs: Tengo a tus mudanzas miedo. / MARC.: Si me mudo, te amaré. / GinÉs: ¿Y mudaráste? MARC.: No sé. / GINÉs: Con buena esperanza quedo. / MARC.: ¿No dices que he de mudarme? / GINÉs: Sí. MARC.: Pues si lo sabes, cierto / no harás mucho en aguardarme” (vv. 2370-2376).

542 See, e.g.: “¿Qué comedia prevendrán? / Honra y vergüenza reporta / celos que los dos me dan” (vv. 2386 ff.). 
dies for his faith, beginning with the visualization of elements of Christian beliefs and rites that he considers relevant to perfect his portrayal. He discusses how he will first invoke Christ and Mary - a scene which he declares is very well written ("[...] pienso que muy bien / todo aquel paso escribí" vv. 2427 f.). He will then plead with the saints, tear down the idols in anger, show himself as if he were being tortured, and become aware of how the firmament was opening and a martyr was speaking to him or he to him. This scene too he praises with the words "ibravo paso, industria brava!” (v. 2441). Finally, he will end by scolding the emperor for being a cruel man. He then recites an empassioned speech, continuing to comment on his own performance ("bien voy, bien le muestro furia” v. 2445; “iQué bien levanto la voz!” v. 2453). While rehearsing, however, Ginés apparently works himself more and more intensively into the state of a Christian martyr, to the extent that he pleads to receive the grace of baptism:

\author{
Ahora volverme quiero \\ al cielo, y llamar los santos, \\ como que su gloria espero \\ para ser uno de tantos \\ por este tormento fiero. \\ Santos mártires, rogad \\ a Cristo, en cuya Pasión \\ hallasteis facilidad \\ para tormentos, que son \\ de menos atrocidad. \\ Que me dé esfuerzo y valor; \\ y pues no puedo, en rigor, \\ porque lo decís vos mismo, \\ ir a vos sin el bautismo, \\ dadme el bautismo, Señor.
}

(vv. 2454-2468)

When he speaks these words, 'heaven opens' and the Holy Mary, Jesus Christ, and God the Father appear on the heavenly throne, surrounded by several martyrs. ${ }^{543}$ Ginés does not react to this phenomenon - the impressive image is obviously visible to the spectators/readers but not to the protagonist, or, rather, it is suggested that he does not (yet) want to see it. Ginés does notice, however,

543 The stage direction says: "Con música se abran en alto unas puertas en que se vean pintados una imagen de Nuestra Señora y un Cristo en brazos del Padre, y por las gradas de este trono algunos mártires.” (in the edition used here on p. 138). For the contemporary realization of the scene in terms of stage machinery, see Aszyk, "Hacia una reconstrucción de la puesta en escena original de Lo fingido verdadero" (cf. note 487), p. 173. 
that his request for baptism is not in the script ("¿Cómo dije que pedía / bautismo, pues no escribí / lo del bautismo aquel día?” vv. 2469-2471), ${ }^{544}$ and that he has heard celestial sounds ("¿Y cómo en el cielo oí / tanto aplauso y armonía?” vv. 2472 f.), but he immediately rejects this as a sensory delusion ("Mas débome de engañar;" v. 2474). With the aim of being able to play his role as a Christian even more convincingly in the performance before the emperor (because: “¿qué mejor puedo imitar / si fuera el cristiano mismo / que se pretende salvar?" vv. 2476-2478), he repeats the plea for baptism. ${ }^{545}$ Thereupon, a voice announces him that his acting will not be in vain, but that he will be saved ("Voz: No le imitarás en vano, / Ginés; que te has de salvar" vv. $2487 \mathrm{f}$.). The visibly confused Ginés concludes that one possible explanation for what he just heard is that one of the actors from his group, having observed his rehearsal, had given him this cue from afar. ${ }^{546}$ However, he also immediately considers that what he heard was not an imitation, not part of the play, but actually the voice of Christ calling him with the promise of the salvation of his soul through baptism:

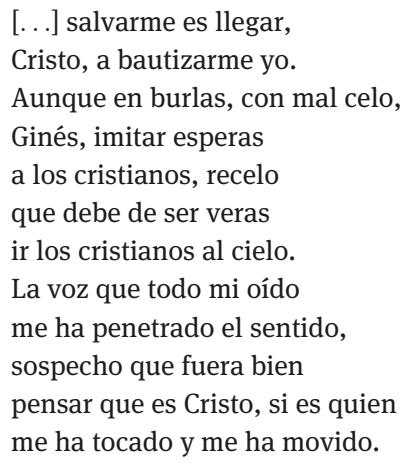

(vv. 2497-2508)

Ginés' thoughts now revolve around Christian beliefs and his own inner reaction, still inexplicable to him, to this 'call from heaven,' which he is not sure is

544 Thus, it can be assumed that the explicit request for baptism has so far not been part of Ginés' repertoire in the role of the Christian. The interpretation that Ginés previously performed himself into a state of frenzy remains an interpretation that is in principle only possible in retrospect.

545 "Ea, pues: a decirlo vuelvo: / santos, rógadselo a Dios, / pues a serlo me resuelvo; / tenga yo el cielo por vos. / ¡Que de quimeras revuelvo, / con deseo de acertar / a imitar este cristiano / que el César manda imitar!” (vv. 2479-2486).

546 “[ . . ] sería, / aunque lejos de este puesto, / alguien de mi compañía / que me vió tratando desto. / ¡Oh, qué bien me respondió! / La voz del cielo imitó;” (vv. 2490-2495). 
authentic or sensory deception (" ¿Qué me espanta / que penetre mi sentido / su nombre con fuerza tanta?” vv. 2531-2533). According to the Christians, Ginés continues, Jesus Christ died in torment for mankind and thereby opened for them the gate of heaven closed by sin. Baptism was necessary to enter heaven, those who moved away from God would go to hell, and therefore it was not surprising that Christians died for their Lord. ${ }^{547}$

So absorbed is he in his thoughts that he does not even seem to notice that the young actor Fabio has joined him ("FaBIO: Divertido, / no me ha visto" vv. 2530 f.) and he is therefore hardly able to follow Fabio's words. The latter complains to Ginés that Marcela had just assigned him the role of the angel, which was supposed to be her role, and voices his concern that given this late assignment he does not know his text and is concerned that the performance will be a failure as a result. This leads to several misunderstandings. When Ginés apologizes to Fabio for his inattentiveness by saying that when he played the Christian, he was so 'beside himself' and 'enraptured' that he thought the 'sublime angel' had spoken to him ("Perdona, que divertido / en imitar al cristiano / fuera me vi de sentido, / pensando que el soberano / ángel me hablaba al oído" vv. 2554-2558), Fabio does not really understand what Ginés is talking about, and replies: "Yo soy quien de ángel te hablé" (v. 2560), for he had been talking to him about the angel ("GinÉs: ¿Tú del ángel? FABIO: Ginés, sî.” v. 2561). Ginés interprets this sentence according to his first assumption about the ontological status of the words he had heard, namely that he was not playing in vain and that his soul would be saved. Consequently, it had not been a heavenly voice, but Fabio, who had approached him 'as angel' (also "de ángel”), as actor in the role of an angel: "Luego en la voz me engañé, / que ser del cielo entendî" (vv. 2562 f.). Fabio then attempts to explain Ginés' supposed encounter with the supernatural by attributing it to his worldly desire for love, in particular his love for Marcela. A theory that Ginés rejects: "Como Marcela es tu cielo, / y el ángel había de hacer, / pensando en ella recelo / que piensas que ha de poder / glorificarte en el suelo" (vv. 2564-2568). Shortly thereafter, Ginés reiterates his doubts about what he had perceived: either he had been deceived by heaven, or heaven had truly spoken to him, and he immediately reverts back to the explanation that it must have been Fabio's voice ("O el cielo de burlas anda, / o sentí su voz suave. / Mas Fabio debió de ser / que en lo del ángel me habló” vv. 2572-2575). Regarding the last words spoken in this scene - "¡Cristo mío, pues sois Dios, / vos me llevaréis a vos, / que yo desde ahora os sigo!” (vv. 2586-2588) - it cannot be clearly determined, however, whether Ginés expresses himself here as Ginés,

547 Vv. 2509-2516, vv. 2518-2520, vv. 2537-2540. 
i.e. whether he 'speaks in earnest' and thus already at this point his 'inner transformation' to Christian faith has taken place, or whether the utterance is made 'in play,' i.e. in the role of the Christian, inasmuch as shortly beforehand Ginés announced that he wanted to go through the text again with Fabio (v. 2584).

Diocleciano, Camila, Maximiano, and Léntulo take their seats and the second 'play within the play' of Lo fingido verdadero begins, this one however is not a comedy but a tragedy ("CAMILA: Silencio, que comienza la tragedia" v. 2601). As in the second act, the actual performance is preceded by a short piece of music that outlines the foundations of Christian faith, the incarnate Logos and Jesus Christ's redeeming death as well as martyrdom as a guarantor for an eternal life in the kingdom of God (vv. 2602-2613). This not only sets the theme for the inner play, but also foreshadows the later events of the last act, and it is preceded by a loa presented here by Marcela (vv. 2614-2679). According to tradition, the loa is addressed to whatever rulers are present and evokes their generosity. For this purpose, the image of the generoso elefante (v. 2614) is used. The naturalists told of the strange and incredible characteristics of this animal, begins Marcela's speech and she goes on to mention the case of an elephant who had learned to write (vv. 2619-2629), and an elephant who had sadly plunged into the sea after another had been preferred to him in war (vv. 2630-2637). These were individual cases, but they were said to have two things of a general nature, which were useful to express her (Marcela's) intention. First, when elephants passed through a herd of lambs, they would push them aside with their trunks so that they would not trample over them; second, if a herd of elephants reached a river, they would always let the smaller ones pass first and safely reach the other bank, fearing that if large and small animals crossed the river at the same time, the water could rise to such an extent that the smaller ones would be in danger of drowning (vv. 2642-2655). ${ }^{548}$ Marcela then relates this image of the 'magnanimous elephant' panegyrically to the performance situation: the actors are compared to a 'poor, humble herd of gentle lambs' who had come to the field with their 'autor' Ginés and served the Caesars devotedly. She hoped that the emperors, to whom the whole world surrendered, would use their invincible

548 The qualities of elephants presented by Marcela, both those of the 'astonishing individual cases' as well as the latter two, can be found in Pliny (cf. Naturalis historia VIII, chap. 5 [When crossing waters they first let the small elephants pass; Suicide of an elephant out of disgrace, here, however, by starvation]; VIII, chap. 3 [an elephant that was able to write]; VIII, chap. 7 [Elephants behave considerately against weaker animals, they push aside sheep with their trunk in order to not step on them] [Gaius Plinius Secundus, Naturalis historia/Natural History, Latin-English, trans. and ed. Harris Rackham, 10 vols., London/Cambridge, MA 1958-1966, vol. 3 (1961), pp. 6-19]). 
hands' to brush aside their humility (that of the 'actors-lambs') ("Si dos Césares contemplo / que en aqueste campo asisten, / donde, cual tiernos corderos, / manada pobre y humilde, / vienen con su autor Ginés, los que humildemente os sirven, / bien será que desviéis / con las manos invencibles / nuestra humildad, siendo a quien / toda la tierra se rinde;" vv. 2656-2665). It was due to them, the emperors, that they could all cross the great waters unscathed - i.e., that the performance would run well - thus, Marcela asks the imperial highness to step aside and watch them from the outside until they (the actors) safely reached the other side - that is, to clear the stage for the theater performance ("y si en mar de tal grandeza, / [. . ] / habemos de estar, señores, / advertid que no es posible / que nos dejéis anegar; / y así es justo que que os suplique / que la Majestad se aparte, / y desde fuera nos mire / hasta que estemos en salvo, / porque ninguno peligre; / haced nos este favor [.. .]" vv. 2667-2676).

As Nolting-Hauff ${ }^{59}$ points out, the images evoked in the loa are emblematic: 'Elephant lets a lamb pass' (“Elefant läßt Lamm vorbeigehen”) means 'humility overcomes pride' ("Demut überwindet Hochmut”), 'Elephant lets lambs pass' (“Elefant läßt Lämmer vorbeigehen”) stands for 'leniency of the ruler' ("Milde des Herrschers"). ${ }^{550}$ She also draws attention to another dimension of the simile: allegorically elephants also stand for 'terrible sinners who Christ converts and uses for the ornament of the Church' ("Elephantes [...] designare possunt immanes peccatores, quos convertens Christus, utitur illis ad ornamentum Ecclesiae [...],” as it says in Hieronymus Lauretus' Silva allegoriarum). ${ }^{551}$ Consequently, according to Nolting-Hauff, 'the two pagan emperors are reproached here with the counter-image of their successors converted to Christianity. ${ }^{, 552}$ Another aspect of the images used in the loa also seems worth mentioning in the context of Christian symbolism (pastor and agnus) and thus with regard to the anticipation of the coming events in the play: if, in the comparison that Marcela draws between the actors and a flock of lambs, Ginés, in his role as autor is compared to a shepherd, this may already allude to the fact that he later actually professes himself to Christ, the 'good shepherd,' and is prepared to die a martyr's death for his faith, which in turn represents an imitatio of the Passion of Christ, the sacrificial death of the 'Lamb of God.'

549 Nolting-Hauff, “Lo fingido verdadero" (cf. note 491), pp. 78 f. with note 29 (p. 87).

550 Henkel/Schöne (eds.), Emblemata (cf. note 536), cols. 414 ff.

551 Hieronymus Lauretus, Silva allegoriarum totius sacrae scripturae (1570), intr. Friedrich Ohly, Munich 1971 (repr. of the 10th edition: Cologne 1681), p. 384.

552 Nolting-Hauff, "Lo fingido verdadero" (cf. note 491), p. 79 (“[...] den beiden heidnischen Kaisern [wird] das Gegenbild ihrer zum Christentum bekehrten Nachfolger vorgehalten [...]”), with note 30, p. 87. 
At the beginning of the play, Ginés, accompanied by soldiers, enters the stage as a captive Christian ${ }^{553}$ who joyfully looks forward to martyrdom and death ("Contento a la muerte voy. / [...] / Maltratadme, despreciadme, / mostrad en mí vuestras furias, / decidme infamias e injurias, / y a vuestro gusto llevadme; / que por Cristo todo es gloria” vv. 2683-2692). The immediate reactions of Diocleciano and Maximiano to this performance already point to aspects that will soon be relevant on the level of 'reality' of the play. Diocleciano’s remark, “iQué bien comienza la historia! / Este cristiano va preso” (vv. 2695 f.), shows explicitly, for the first time, his (historically accurate) character as a harsh persecutor of Christians and points to the arrest of the 'Christian Ginés' that he later orders be carried out. Maximiano's statement, made as a compliment to the acting performance, “Represéntale Ginés / que parece que lo es, / y verdadero el suceso" (vv. 2697 ff.), manifests the difficulty of distinguishing between fingido and verdadero. As will become apparent in the further course of the 'play within the play' and the merging of fiction and reality, what the audience - not least because of the convention, i.e. the situation designated as 'play' - classifies as a perfect representation precisely because it accurately reflects the imitated original, actually corresponds to reality. Ginés' acting persona ellides with Ginés the person. When Ginés then asks for baptism, not without mentioning the possibility of 'blood baptism' (“iAy, Señor! ¡Quién estuviera, / ya que es vuestro, bautizado[!] / [ . . ] / [ . .] bien sé que basta / mi sangre" vv. 2700-2705), one of the players representing the soldiers notes that these lines were not in the text, but another immediately refers to Ginés' talent for improvisation, saying that he was probably embellishing the performance in order to impress the emperor. An angel appears above the stage and asks Ginés to come up to him so that he could baptize him ("ÁNGEL: Sube, sube, llega a verme; / que te quiero bautizar" vv. 2716 f.; the stage direction reads: "UN ÁNGEL en lo alto.”). Ginés follows this command, saying that his innermost wish will now be fulfilled ("Señor, aunque no sé hablar, / Tú sabes bien entenderme; pues este lenguaje mudo / de mi pensamiento entiendes; / llévame donde pretendes” vv. 2718-2722; stage direction: “Sube Ginés donde está el ángel.”). The scene is again commented on by both the actors and the spectators. While the former discuss the deviation from the intended play ("CAPITÁN: El fin deste paso dudo; / que no se ensayaba así” vv. 2723 f.), the latter explain it to each other in the context of the Christian conception of faith, which they condemn. ${ }^{554}$ Ginés'

553 The Capitán addresses Ginés with "León” (“CAPITÁn: Mucho, León, replicáis.” [v. 2682]), this, however, is the only reference in the entire drama to Ginés' stage role name as a Christian. 554 E.g.: "DiocL.: Ginés / finge ahora que después / que a Jesucristo adoró, / que es el Dios de los cristianos, / aquel ángel viene a verle, / a enseñarle y defenderle. / MAX.: ¡Qué de encantamientos vanos!” (vv. 2729-2735). 
baptism has just taken place, and he had now disappeared behind a curtain ${ }^{555}$ (and is standing on the corridor above the stage): music sounds and four angels with corresponding objects (baptismal font, aquamanile, white baptism candle, and baptism bonnet) become visible above the stage (for the spectator/reader as well as for the internal audience). ${ }^{556}$

Ginés' speech that follows these events (vv. 2744-2757), is in sonnet form and addressed to the Christian God. In it he praises God's omniscience ${ }^{557}$ and potency, referring to persons and events of both the Old and the New Testament that prefigure the 'proclamation of God' or the salvation of a sinner. ${ }^{558}$ Likewise, he, Ginés, a 'sinner converted to the true faith,' strives, through his life or rather by his death, to be 'the proclaimer of faith. ${ }^{, 559}$ Ginés formulates his willingness to sacrifice himself ("bendecid este pan, pues vuestro es" vv. 2754) and asks God to 'play' with him together from now on: "Representad conmigo desde hoy más; / haced vos las piedades de Jesús, / que yo haré los martirios de Ginés” (vv. 2755 ff.). The spectators continue to be full of praise for what they still consider a performance. Their enthusiasm culminates in Léntulo's paradoxical statement: "No hay diferencia / desto al verdadero caso" (vv. 2760 f.). ${ }^{560}$ The scene seems so well done that from

555 “CAPITÁN: ¿Adónde va por allí? / SOLDADO: No sé; mas ya se cubrió / de una cortina” (vv. $2727 \mathrm{ff}$.).

556 The stage direction reads: "Descúbrese con música, hincado de rodillas, un ángel; tenga una fuente, otro un aguamanil levantado, como que ya le echó el agua, y otro una vela blanca encendida, y otro un capillo" (p. 147). For the practical realization of the scene on the corral stage, see Aszyk, "Hacia una reconstrucción de la puesta en escena original de Lo fingido verdadero" (cf. note 487), pp. 175 f. ('en lo alto' refers to a corridor above the stage, which could be reached via a staircase inside the dressing-room. The Corral del Príncipe, the theater which Aszyk refers to in her scenographic reconstruction, was equipped with two such corridors above the stage. When Ginés [or more precisely the actor playing Ginés] disappears behind the curtain, he goes via the dressing-room up to the corredor superior, where the actor who played the angel that called for Ginés was previously standing. It is from here that Ginés gives the subsequent monologue. Then the curtain of the upper stage level closes again and the actor returns to the main stage through the dressing room.).

557 "Señor divino, que miráis y oís / los pensamientos, porque en fin, sois Dios" (vv. 2744 f.). 558 Mention is made of the prophet Amos (“[. . .] un profeta hacéis de un rudo Amós" v. 2746), the apparition of Jesus on the road to Emmaus ("y os mostrasteis ser Dios en Emaús" v. 2753), the salvation of Jonah from the belly of the whale ("vos, que del mar sacasteis a Jonás[,]" [v. 2752]), the resurrection of Lazarus ("y un Lázaro difunto revivís" v. 2747) and the so-called 'good thief' (“vos que un ladrón donde reináis subís, / porque muriendo se convierte a vos;” vv. 2748 f.).

559 For this passage, see Nolting-Hauff's elaboration on the typoi referring to the protagonist: "Lo fingido verdadero" (cf. note 491), p. 77.

560 Cf. as well: "CAmila: ¡Cuál estaba en el bautismo / imitando a los cristianos, / humilde y puestas las manos!", and Diocleciano's answer to this: "Parece que lo es él mismo" (vv. 2762-2765). 
the stage audience's perspective there is no discernible difference between 'play' (the fake conversion and baptism) and 'reality' (true conversion). Only in retrospect will they begin to suspect that what they thought was fictitious must already have been reality itself. Ginés, who has returned to the actual stage (he had delivered his monologue while 'en lo alto,' i.e. in the corridor above the stage ${ }^{561}$ proceeds with his speech and calls for his martyrdom (“¡Ea, amigos, que ya vengo / contento al martirio; vamos!” vv. 2774 f.). The actors are confused, since this part of the speech was not in the original script: "en todo el papel no tengo / ese paso ni ese pie" (vv. 2777 f.), says one of the soldier actors, and finally call several times for the prompter ("CAPITÁN: Dile que apunten allá, / que va perdido Ginés. / SOLDADO: ¡Hola! ¡Apunten!” [vv. 2794 ff.], a little later: “CAP.: Apunta, que va perdido. / Cuanto dice es de repente” vv. 2826 f.). Ginés, however, does not appear to be 'enraptured' in the sense that he is not capable of responding to his fellow actors. ${ }^{562}$ In fact, he takes up the theatrical vocabulary used by them, integrates it into his speech as a new Christian who repents of his sins and looks forward to entering God's realm after death, expanding on the theatrical metaphor of life as the earthly 'stage' and the afterworld of the kingdom of God as true reality. God was his prompter, who had assigned him the role and the words:

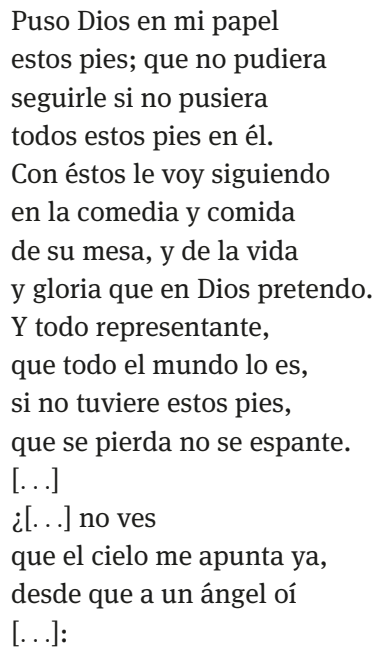

561 "Esto se cierre todo." (after the sonnet) and "Vaya saliendo de arriba, y bajando, Ginés." (after the comments by the audience), according to the stage directions (p. 148).

562 In principle, it is still possible at this point, from the perspective of the audience/readers, to classify what is happening as the improvisation of the 'brilliant actor Ginés.' 
"Camina, Ginés, camina,

Ginés, que él lo dice asî”?

(vv. 2782-2801)

Using acting metaphors, Ginés describes his conversion from sinner to Christian preacher of God. His role had been wrongly written, he had been mistaken, ${ }^{563}$ but after the 'angel from the heavenly dressing-room' gave him the right cue, showed him the right way, he had given himself to God, had sincerely played the comedia before and for God and would now be "el mejor representante" (v. 2825), the 'best actor,' i.e. representative of faith ${ }^{564}$; he had learned all this, he adds, 'through a miracle' (“[...] milagrosamente / es todo aquesto aprendido" vv. 2828 f.).

The confusion on stage intensifies and extends to the audience, when Fabio finally enters the stage as an angel in order to perform the baptism of Ginés, as planned in the play. There is a dispute between Fabio and the Capitán, who reproaches Fabio for repeating the passage, since the scene of the baptism had after all already been played. Fabio replies that this was simply impossible, for he was entering the stage as an angel only now, for the first time. ${ }^{565}$ At this point, in retrospect, it becomes clear that the first angel had been a real one, and that the first baptism actually took place. Diocleciano, angry about the argument on stage, demands that they respect his imperial presence and, after Ginés interjects to take the blame for the confusion, asks, indignantly, why they would put on a comedia in the first place, if they could not master it (vv. 2838-2845). At the Capitán's request, however, Diocleciano attests to having seen the angel, but thinks, as do the rest of the audience and the other actors, that this had been the actor Fabio. Though the latter continues to assert that he had not previously appeared as an angel, neither the actors nor the audience believe him. ${ }^{566}$ It should be noted that a structural element of

563 "Estaba el papel errado: / donde Dios decir tenía, / demonio, amigos, decía, / y donde gracia, pecado; / donde cielo hermoso, infierno, / donde si errara me fuera, / donde vida, muerte fiera, / donde gloria, llanto eterno;" (vv. 2802-2809).

564 "pero después que apuntó / el ángel del vestuario / del cielo, y lo necesario / para acertar me enseñó, / yo dije a Dios mi papel / [ . . ] / [ . .]. / Oyeron de mi buen celo / la comedia, y era justo, / y en verdad que di gran gusto, / pues que llevan al cielo. / De Dios soy de aquí adelante, / que siéndolo de su fe, / dice el cielo que seré / el mejor representante” (vv. 2810-2825). 565 Cf. vv. 2830-2837.

566 "CAP.: ¿No vió aquí tu majestad / el ángel? DiocL.: Sí. CAP.: Pues porfía [Fabio]/ que no ha salido, y quería / volver al paso. DiocL.: Es verdad. / FABIO: Gran césar, si se probare / que yo he salido, te pido / que me cortes la cabeza. / DiocL.: ¿Pues no te he visto yo mismo? / CAmila: ¡Hombre, ¿qué dices? Que yo / y todos te habemos visto! / FabIo: Señores, que no era yo; / mirad bien, que yo no he sido. / MAX.: Calla, necio, que estás loco" (vv. 2846-2858). 
the first 'play within the play' of the second act is repeated here: the boundary between fiction and reality is crossed on the level of the relation between stage and audience. Rather than merely 'watching' the play, the spectators are now actively interacting with the actors.

Ginés now intervenes again, exonerates Fabio and provides the explanation for the incident. It was not Fabio, but rather a heavenly witness, a real angel, who had spoken ("Bien dice, que un Paraninfo / del cielo, con voz divina, / todo su papel ha dicho. / [...] / Un ángel / que me enseñó un sacro libro, / donde vi lo que aprendí, / que es esto mismo que digo" vv. 2859-2865). Although keeping to theater imagery, Ginés now explicitly professes that he is no longer playing the part of a Christian, but is one in fact. His autor was Jesus Christ, the second act of this other, real, 'play' was about the wrath of the emperors, the third about his martyrdom: "Césares, yo soy cristiano: / ya tengo el santo bautismo: / esto represento yo, / porque es mi autor Jesucristo; / en la segunda jornada / está vuestro enojo escrito; / que en llegando la tercera / representaré el martirio" (vv. 2866-2873). He further declares, in response to the emperors' question, that he is not jesting or deluded. He confesses his Christianity, in full earnestness; calls the emperors tyrants ${ }^{567}$; and renounces the Roman gods. The emperor, finally realizing that this is no longer a stage play, sentences Ginés to death and orders the arrest and interrogation of the other actors in the troupe. ${ }^{568}$ The play has turned serious. Ginés is put in chains and taken away (vv. 2900-2905).

In the next scene the actors are being interrogated by Senator Léntulo. ${ }^{569}$ He is compassionate, finding them harmless ("El veros me da dolor; / prenderos

567 "Diocl.: ¿Hablas de veras, Ginés? / MAX.: Di, Ginés, ¿tienes juïcio? / Ginés: De veras hablo, tiranos" (vv. 2874 ff.). Here, too, the parallels to the first play within the play (see vv. 2034-2057) are worth mentioning. Having heard the news of Octavio's and Marcela's disappearance, Ginés turns directly to the Emperor with a request to look for them. Diocleciano does not know whether this is part of the play or not and asks "¿Hablas de veras o no?" (v. 2057). While in the first instance Diocleciano considers the confusion in the first case to be a successful burla, i.e. part of the performance, he here finally takes Ginés at his word and consequently condemns him to death.

568 Even Diocleciano places his sentencing in the context of the stage, which becomes the tribunal, with him in the role of judge, and takes on (as a Roman ruler who persecutes of Christians) the role assigned to him by Ginés' confession: “[. . . ] yo quiero hacer mi dicho, / y morirás en comedia, / pues en comedia has vivido. / Siéntome como tribuno: / traedle aquí. / [...] / Pues yo te sentencio a muerte: / mira qué breve juïcio; / y acabaré mi papel / con que Léntulo y Sulpicio / prendan y examinen luego / a cuantos vienen contigo" (vv. 2881-2893). The passage in total: vv. 2874-2897.

569 Vv. 2906-2965 
es crueldad;" vv. 2954 f.), believes that they are not Christians and releases them, but exiles them from Rome. However, this takes up only a fraction of the interrogation. ${ }^{570}$ The emphasis in this scene is rather on their respective roles within the ensemble; they are asked their names and the roles they generally play. ${ }^{571}$ Ginés enters in chains. In his monolgue directed at God in the form of a sonnet, again using the contrasting pair 'burlas-veras,' which refers to the comedia's motto, 'lo fingido verdadero.' In his monologue he again uses theatrical metaphors to describe his miraculous conversion to Christianity, the divine grace which he was thereby granted, and his willingness to die for his faith. He summarizes what has happened to him since the 'call from heaven' during his rehearsal of the role of the Christian, which had been at the time incomprehensible to him:

Mi Dios, cuando por burlas fui cristiano

y me llamastes a tan altas veras,

representaba burlas verdaderas

en el teatro de mi intento vano.

Mas como el auditorio soberano

en las gradas de altísimas esferas,

$\mathrm{y}$ vos por las celestes vidrïeras

vistes de mi comedia el acto humano,

he pensado que lástima tuvistes

que estuviese en tan mala compañía,

y que para la vuestra me quisistes.

570 "LÉNT.: responded con brevedad, / ¿sois cristianos? TODOS: No, señor. / LÉNT.: Pues con esa confesión / sólo salid desterrados / de Roma” (vv. 2956-2960).

571 Octavio plays "galanes" (v. 2919), Sergesto "rufianes, / el soldadillo perdido, / el capitán fanfarrón, / y otras cosas de este modo" (vv. 2920-2923), Fabio "muchachos [...] / [...] príncipes, y otras cosas / de tierna edad" (vv. 2926 ff.), the actor Albino plays "graciosos, / desdichados no dichosos" and "pastores” (vv. 2931-2934), Fabricio “[...] los padres y reyes: / figuras de gravedad" (vv. 2942 f.), the actress Celia takes the parts of "[s]egundas damas, / las criadas y pastoras" (vv. 2946 f.) etc. Also in Ribadeneyra's vita-version, the other actors are immediately suspected of being Christians like Ginés and shall be punished. However, there the argument takes place in direct confrontation with an extremely furious Diocleciano, there is no ordered interrogation. The actors not only deny that they are Christians, but they explicitly distance themselves from Ginés and curse the Christian god as proof. There is no mention of a banishment from Rome in the text, the emperor lets go of them to focus his anger fully on Ginés again. (“[...] [E]llos le [a Diocleciano] dixeron que no eran Christianos, ni estauan engañados como Gines: que lo que el Emperador crehia, crehian ellos, y adorauan a los dioses que el adoraua: que si lo pecò Gines, no era justo que lo pagassen todos. Y para que viesse el Emperador que no era[n] Christianos, dixeron grandes blasfemias contra Christo. Entonces el Emperador, dexando a los otros, se embraueciò mas contra Gines [. . .]" [Ribadeneyra, "La vida de san Gines" [cf. note 495], pp. 360b f.]). 
Dadme partido vos, que yo querría estar con vos; pero si entero os distes, en vos acabe la comedia mía.

(vv. 2966-2979)

The form of the sonnet, which occupies a special position in the polymetry of the Spanish comedia, ${ }^{572}$ is used three times in Lope's drama. All three sonnets (vv. 2325-2338/2744-2757 and above) are spoken by the protagonist. While the position and content of the individual sonnets are already striking, comparing them to one another highlights a central aspect of the character: his transformation from a person devoted to worldly love to a person committed to Christian love who is prepared to die for his faith out of love for God. The first sonnet is situated at the beginning of the third act after Ginés' conversation with Diocleciano, in which he articulates his forgiveness and lack of jealousy towards the returned Marcela. In the sonnet, in what is a departure from the sensuality of this world - with Marcela as the object of desire - the idea of 'false' love emerges. Love consumed by jealousy appears to Ginés now ('con desengaños' v. 2331) as locura (v. 2332). ${ }^{573}$ The second soliloquy/sonnet is delivered by Ginés during the second 'play within the play,' immediately after the baptizing scene (which, now in retrospect becomes apparent as having been authentic). He addresses himself to God, praises his omnipotence with reference to biblical examples, and expresses - using the theater metaphor - his own readiness to give himself completely to God and to die for his faith; asking God 'to play together with him' from now on, and declaring that he himself would perform 'the martyrdom of Ginés.' The central Christian conversion ritual is thus followed by an explicit (and in its consequence also extraordinarily extreme) acceptance of Christianity and request for divine grace, in other words,

572 See, for instance, Georges Güntert, "Función del soneto en el teatro áureo: ¿pausa reflexiva del personaje o tematización del drama?”, in: Itzíar López Guil/Jenaro Talens (eds.), El espacio del poema: Teoría y práctica del discurso poético, Madrid 2011, pp. 205-223. However, in Lope's Arte nuevo it says in this regard only: “el soneto está bien en los que aguardan;” (v. 308 [Lope de Vega, Arte nuevo de hacer comedias (cf. note 503), p. 148]).

573 Regarding this passage, see also already above p. 202 (the sonnet once again: 'Amor me puso en tanta desventura / la verde primavera de mis años, / que pensé por el mar de sus engaños / en vez del puerto hallar la sepultura. / Y aunque este fuego en las cenizas dura, / ya con menos rigor siento sus daños; / amé con celos, mas con desengaños / no pienso que es amor, sino locura. / Bien pueden mientras viven engañados / conservarse en la fe de amor fingido, / de un ofendido amante los cuidados. / ¿Y qué importa que quiera el ofendido? / Que quien ama con celos declarados, / ya llega a los principios del olvido’ vv. 2325-2338). 
a conscious turning towards agape..$^{574}$ The third sonnet does not come in the context of internal fiction. Ginés has been sentenced to death by Diocleciano, and there is nothing standing in the way of his 'real' dying as a martyr. As a Christian, he no longer apostrophizes God with the general '[s]eñor divino' (v. 2744), but with the possessive pronoun 'my' ('Mi Dios' v. 2966) and reflects on his unexpected change continuing to use the motif of lo fingido-lo verdadero. He now realizes that when he played the role of a Christian, he was a Christian for the sake of mockery, and when on the 'stage of his vain intention' the call of God, the truth, reached him and mockery changed to reality ('Mi Dios, cuando por burlas fui cristiano / y me llamastes a tan altas veras, / representaba burlas verdaderas / en el teatro de mi intento vano' vv. 2966-2969; my italics).

The central aspect presented here in nuce is that the borderline between play and seriousness, appearance and being, deception and truth, is a fragile and permeable one. ${ }^{575}$ The grace of God, Ginés recognizes, has put him on the right path, proclaiming that 'the audience of heaven' ('el auditorio soberano / en las gradas de altísimas esferas' vv. 2970 f.) had watched his performance, and God had felt compassion because of his bad (acting) company and called him for his own ('[...] lástima tuvistes / que estuviese en tan mala compañía, / y que para la vuestra me quisistes’ vv. 2974 ff.; my italics). Again, he asks for a role (in the divine play): 'Dadme partido vos, que yo querría / estar con vos;' (vv. 2977 f.), namely the martyrdom mentioned at the end of the second sonnet ('yo haré los martirios de Ginés' vv. 2754).

One of the prison guards enters, saying that Diocleciano had ordered Ginés' death by impalement, which he intended to attend after the circus spectacle with the wild animals (vv. 2982 f.). Ginés continues his speech about his

574 For the second sonnet, see above p. 210 with notes 557, 558, and 559 (this sonnet in its entirety: "Señor divino, que miráis y oís / los pensamientos, porque, en fin, sois Dios, / y un profeta hacéis de un rudo Amós, / y un Lázaro difunto revivís; / vos que un ladrón donde reináis subís, / porque muriendo se convierte a vos; / vos, segunda persona de las dos, / en cuyo trono celestial vivís, / vos, que del mar sacasteis a Jonás, / y os mostrasteis ser Dios en Emaús, / bendecid este pan, pues vuestro es. / Representad conmigo desde hoy más; / haced vos las piedades de Jesús, / que yo haré los martirios de Ginés” vv. 2744-2757). The turning towards 'true' love implies a now conscious turning away from Eros, which was implicitly hinted at in the first sonnet. (Even if there is no explicit mention here of 'amor [verdadero]' or the like, this concept is of course, as core of the Christian faith and its message, always conveyed as well with the fields that are touched on in the sonnet - like 'God's omnipotence,' 'proclamation of God,' 'converted sinners.').

575 According to the world concept underlying this comedia, absolute knowledge is confined exclusively to the God who governs everything; what is left for man is faith (in what is right), and recognition, which is ultimately only possible from a retrospective view. 
conversion - remaining in the imagery of theater and acting - and prepares himself for martyrdom. In this, he elaborates on the (from a Christian point of view classical) comparison between good and evil, sacred and diabolical, and evokes an image of two groups of actors that he had used in the second sonnet: on the one hand, "la compañia / del demonio" (vv. 2994 f.), of which he had been a member, and on the one hand, the "compañía / [. . .] de Jesús" (vv. 3000 f.), in which he was now playing. ${ }^{576}$ The devil, director of the bad, evil theater troupe, is described as an arrogant, cruel actor, who "[...] por imitar a Dios, / erró el papel, que en los dos / es el saber muy distante [. . .]” (vv. 2997 ff.). With regard to the 'divine' company of actors, Ginés mentions, in addition to God the Father, the Holy Spirit, and the Virgin Mary (vv. 3001-3005), as well as a number of other 'actors' and their respective roles, i.e. relevant figures from the Bible and hagiography, such as John the Baptist, "[...] que hacer puede / pastores en el desierto, / y música a tal concierto, / que al de los cielos excede" (vv. 3006-3009), John the Evangelist ("hay un Juan que habla altamente" v. 3010), David ("hay un David, gran poeta, / y una comedia perfeta / de cantares excelente” vv. 3011 ff.), Peter ("un pontífice eminente / hace Pedro con gran fe” vv. 3014 f.), Mary Magdalene (vv. 3018 f.), Dismas - 'the good thief' ("Hay un famoso ladrón, / Dimas, de poco papel, / pero dijo más en él / que en sus libros Salomón” vv. 3020-3023), the Archangel Gabriel (vv. 3030 f.), Paul, who performed brave and strong men that had been disarmed (vv. 3034 f.), Saint Francis ("Francisco hará los que imitan / a Dios" vv. 3026 f.), and so on. For the members of the 'compañía del demonio' he names Judas, who played traitors, Roman emperors who represented cruelty and tyranny, Lucifer who is in charge of lies and perfidy, while 'the world' played the role of the juvenile lover and the flesh that of the beloved. ${ }^{577}$

In this passage, the category of demonic fingir, a malicious, potentially dangerous deception, comes into play for the first time through the agency of the devil. ${ }^{578} \mathrm{~A}$ role that Ginés declares belongs to both the divine and the

576 See vv. 2974 ff. It is interesting to note that 'Compañía de Jesús' is also the Spanish name of the Societas Jesu, the Jesuit Order, founded by Ignatius de Loyola in 1534, which played an influential role in the Counter-Reformation and the development of theater in Spain.

577 "En esotra compañía / Judas hacía traidores, / romanos Emperadores / la crueldad y tiranía; / Luzbel, mentira y porfía; / el mundo sabe vestir / un galán, y bien fingir / la carne damas de amor;" (vv. 3040-3047).

578 In Lope's comedia, the possibility of a diabolical deception of perception is of no importance. This can be contrasted with the role of doubt in Shakespeare's Hamlet, where Hamlet doubts the truth of his father's ghost and wonders if it is not in fact of demonic origin ('[...] The spirit that I have seen / May be a devil, and the devil hath power / T'assume a pleasing shape, yea, and perhaps, / Out of my weakness and my melancholy, / As he is very potent 
diabolical theatre groups is that of the gravedigger. In the first case, it is played by Nicodemus, in the second, by the figure of the sinner. The difference is, however, that with the Christian promise of salvation, what follows earthly death is resurrection and eternal life: "Nicodemus mete muertos, / pero luego resucitan" (vv. 3038 f.) and "muertos mete el pecador, / mas no vuelven a vivir" (vv. 3048 f.), respectively. Ginés concludes by focusing on 'his role' and the prospect of his martyrdom: "Quiere verme / Dios, que suyo quiso hacerme, / para que el demonio espante, / que represente y que cante / por esta muerte después / en gloria, siendo Ginés / el mejor representante” (vv. 3053-3059). While Ginés illustrates his new belief with the comparison that he was now part of the divine cast of actors (more precisely: its mejor representante) and mentions further actors and the roles they were embodying in both this and the opposing compañía del demonio, it should be noted that the 'worldly' acting group that he had once directed was described primarily using concrete and contemporary repertoire of characters. ${ }^{579}$ The following scene now shows the troupe, sentenced to exile, leaving Rome. They are discussing the loss of Ginés, who had been their manager, director, and best actor, and wondering both who could play his parts, and which plays they would perform, mentioning Ginés' roles as Adonis and Paris. ${ }^{580}$ They reach the Campus Martius, where the execution of Ginés is to take place. Octavio calls it the 'theater' in which Ginés plays out his life and death ("[...][e]l teatro / [...] / donde Ginés representa / su vida y muerte [...]” vv. 3096-3099). Marcela adds that he was speaking to those present there 'in the last act' ("[...] al pueblo circunstante / habla en el acto postrero" vv. $3101 \mathrm{f}$.). In the final image, the impaled Ginés appears (stage directions: "Descúbrase empalado Ginés"). In his last words, he focuses once again on his conversion and at the same time offers the ultimate 'message' of the drama in an explicit formulation of the theatrum mundi ("theater of the world') metaphor (though not without inconsistency). Until his conversion ("recibióme Dios" v. 3110) to a "cristiano representante" (v. 3111) playing in the

with such sprits, / Abuses me to damn me. [...]' [Hamlet 2.2, 594-599]) (see chap. 2 of this study).

579 Vv. 2906-2965, see above p. 214 with note 571.

580 The mention of these very roles refers again to Ginés' life before his conversion, a life oriented towards worldly things and sensual love in particular, i.e., a 'false' life before his conversion to Christianity (cf. in this regard Nolting-Hauff, "Lo fingido verdadero" [cf. note 491], p. 77 ['Ginés-related typoi']). After all, they are two prominent lovers - especially for the physical beauty attributed to them - from Greek mythology, with whom a tragic end is connected (cf., e.g., Ovid, Metamorphoses X, vv. 503-559, vv. 708-739 ['Venus and Adonis'] [used edition: Publius Ovidius Naso, Metamorphoses (Latin-English), trans. and ed. Frank Justus Miller, rev. George P. Goold, 3rd ed., 2 vols, Cambridge, MA 1984]). 
'divine comedia' (“[comedia] divina” v. 3114), he had spent his entire life representing the world's lies, vices, and malice ("yo representé en el mundo / sus fábulas miserables, / todo el tiempo de mi vida, / sus vicios y sus maldades;" vv. 3104-3107); he had played heathens and worshipped pagan gods ("yo fui figura gentil / adorando dioses tales;" vv. 3108 f.). The 'human comedia,' which consisted only of senselessness, was now over ("cesó la humana comedia, / que era toda disparates;” vv. $3112 \mathrm{f}$.): The world, with all its supposed reality is nothing more than theater, it is only appearance. Ginés speaks of the fundamental Christian virtues of fides, spes, and caritas and the reward awaiting him in heaven (vv. 3115-3119). After his death, "la segunda parte" (v. 3121) of the 'comedia divina' would await him, i.e. true and eternal life. Let us quote Ginés' closing words again in their entirety:



(vv. 3103-3121)

Lope's version of the Genesius story differs from its source in several ways. In Ribadeneyra's version of the story, the didactic conclusion focuses on God's "omnipotencia, è infinita bo[n]dad," that is able to "[...] que assi muda los coraçones, y conuierte [...] los perseguidores de Christo en martires de Iesu

581 The metaphor of the 'theater of the world' is inconsistent in the sense that the image of theater is also used for 'eternal life,' the 'true reality in the hereafter,' that is the 'segunda parte' of the 'comedia divina.' 
Christo[.]" ${ }^{82}$ Furthermore, the representation of Ginés' martyrdom differs with regards to the type of execution: death by impalement in Lope de Vega and decapitation in Ribadeneyra; as well as a much more minimal focus on the tortures of the saint that is an important part of typical of this genre. In Ribadeneyra's Flos sanctorum, Ginés is publicly whipped with rods and beaten with clubs, then thrown into prison where he is cruelly tortured, laid on the rack, his sides torn open with iron claws, and burned with torches. ${ }^{583}$ This

582 Ribadeneyra, “La vida de san Gines” (cf. note 495), p. 361b, where God's miraculous activity is manifested spectacularly in Ginés' conversion and martyrdom in the name of faith from the very beginning. The preceding "Vida de San Gines, Escriuano y Martir" (in: Ribadeneyra, Flos sanctorum [cf. note 495], vol. 2, pp. 359a-b) serves Ribadeneyra as a parameter of comparison. According to the legend, this martyr, also named Genesius, was a court clerk in Arles during the reign of Diocletian and Maximian. He refused to write down orders concerning the persecution of Christians, threw his writing utensils at the judge's feet and fled, but was caught and executed on the banks of the Rhône. Christians transported the abandoned corpse to the other bank of the Rhône and buried it there. Ribadeneyra supplements this vita with an account of a 'posthumous miracle' ("posthumen Wunder[s]") characteristic of hagiography (cf. André Jolles, Einfache Formen: Legende, Sage, Mythe, Rätsel, Spruch, Kasus, Memorabile, Märchen, Witz, 8th ed.,Tübingen 2006 [1st ed. 1930], [chap. 'Legende': pp. 23-61], pp. 30-33, quote p. 31, italics in the original): As witnessed by Hilarius, Bishop of Arles, it happened that on the occasion of the feast day celebrated in honor of this saint in Arles there were so many people on the bridge that had to be crossed to reach his church, that it collapsed, threatening to drown countless men, women, old people, and children in the river Rhône. After the bishop had called on Saint Genesius for help, a short time later all people who had fallen into the water actually reached the shore completely unharmed. Although God's work of miracles was shown in the martyrdom of Ginés of Arles and in the miracle performed by his name, the salvation of the people from the floods of the Rhône, the 'milagro' manifested in the actor Ginés had a different dimension, as in this case, the effect had been an 'inner change,' 'a movement of the free human heart,' as Ribadeneyra states in the introduction to the vita of "San Gines el Representante”: “[. ..] pero mucho mas marauilloso se mostrò [el Señor] en la conuersion de otro Gines, haziendole, de representante y burlador, y perseguidor de Christianos, confessor de su santa Fè, y verdadero martir de Iesu Christo. Mayor milagro es trocar vn coraçon, y sacar agua de la piedra, que librar a los hombres de las aguas: porque en lo vno ay sola la obediencia de la criatura, que està sujeta a la voluntad del Señor: y en lo otro ay mudança y rendimiento del coraçon humano, que es libre y señor de si, y resiste a lo que Dios quiere” (Ribadeneyra, "La vida de san Gines” [cf. note 495], pp. 359b f.).

583 Ribadeneyra, "La vida de san Gines" (cf. note 495), p. 361a ("Mandole herir alli luego delante de todo el pueblo con varas, y apalear con gruessos palos, y lleuar a la carcel: y otro dia mandò a vn Prefecto llamado Plauciano, que le atormentasse cruelmente, hasta q[ue] negasse a Christo. Pusieronle en el equuleo, desgarraronle los costados con vñas de hierro, abrasaronle con hachas encendidas. Deziale el Prefecto: Miserable de ti, obedece al Emperador, y sacrifica, y alcançaras su gracia, y viuiras. Respondio Gines: Procuren la gracia y Amistad destos Reyes, los que no temen aquel Rey que yo vi, y adore, y adoro: porq[ue] aquel es el verdadero Rey, que abriendose los cielos yo vi, y vsando comigo de misericordia, me alumbrò con el agua del 
element is completely lacking in Lope. In Ribadeneyra's text, the emperor is described as 'beside himself' with rage, after Ginés had declared before him to be a true Christian; he is so enraged that he almost kills Ginés by himself, ${ }^{584}$ but this is more downplayed in Lope's play. It has already been mentioned that Ginés is not depicted as an explicit persecutor of Christians in Lope de Vega, in contrast to the model text. ${ }^{585}$ Also striking is the change in the play that the actor Ginés is about to perform when his conversion to Christianity comes about. In Lo fingido verdadero, Ginés is the protagonist of a tragedy that revolves around the martyrdom of a Christian. In Ribadenyra, however, the stage play is a kind of farce, more precisely, a very crudely comic mockery of baptism as a purifying ritual, with scatological implications.

[...] [Ginés] fingiò que estaua malo, y echose en vna cama, y llamò a los q[ue] le auia[n] de ayudar al entremes, y como que eran sus criados, dixoles, que estaua malo y pesado (porque era muy gruesso de carnes) y que queria aliuiarse. Passaron algunas razones entre Gines, y sus criados, a este proposito, llenas de donaire y de chacota. Finalmente el dixo, que queria ser Christiano, y vno de los representantes se vistio de Exorcista y otro de Presbitero para baptizarle, haziendo burla con aquella representacion del santo Sacramento del Baptismo, y de la Religion, y ceremonias de los Christianos, con grande gusto del Emperador, y aplauso y regozijo de todo el pueblo. Pero (o bondad inmensa del

Baptismo, y de burlador de los Christianos, me hizo Christiano, y me pesa en el alma de auer perseguido su santo nombre, y conozco que por ello merezco qualquiera pena y castigo. A este Emperador del cielo es justo que obedezca cuyo Imperio durara para siempre, y no a Diocleciano, que es hombre mortal, y su Imperio en el suelo, y presto se ha de acabar. Date (dize) priessa, aumenta las penas y tormentos que por mas que hagas, no apartaras a mi Señor Iesu Christo de mi coraçon. Auisò el Prefecto al Emperador de la constancia de Gines, y del esfuerço y alegria con que sufria los tormentos, y el Emperador le mandò a degollar, y assi se hizo [...]").

584 "[...] quien podra explicar como el Emperador quedò atonito y fuera de si? Y el furor y enojò con que mandò que todos los representantes fuessen traydos a su presencia, y alli açotados, pensando que ellos tambien, como Gines, eran Christianos? Pero ellos le dixeron, que no eran Christianos [. . . ]. Y para que viesse [. . . ] que no era[n] Christianos, dixeron grandes blasfemias contra Christo. Entonces el Emperador, dexando a los otros [representantes], se embraueciò mas contra Gines, y faltò poco que alli con sus manos no le matasse, segun estaua fuera de si” (pp. 360a f.).

585 See the quoted passage from Ribadeneyra above p. 179; cf., furthermore, in the words of Ginés: “Antes de aora, siempre que yo ohia nombrar a los Christianos, ciego y loco en la idolatria, procuraua (como otros) perseguirlos, e incitar al pueblo para que los persiguiesse: y era tal el enojo que tenia contra ellos, q[ue] por esta causa dexè a mis padres y deudos, queriendo antes viuir pobre y desuenturado, que en mi patria entre Christianos. Con este mismo odio determinè estos dias de descudriñar y querer saber las cosas de los Christianos, no para creerlas, sino para mofar dellas y represe[n]tarlas en el teatro, y entretener y alegrar la gente como aueis visto" (Ribadeneyra, "La vida de san Gines" [cf. note 495], p. 360b). 
Señor! o virtud y eficacia de la diuina gracia!) en el mismo tiempo que hazian escarnio de Christo, tocò el Señor el coraçon de Gines, y le alumbro con vn rayo de su luz, y le trocò la voluntad de manera, que no ya por burla, sino de veras deseasse ser Christiano, y recebir el Baptismo [...]. ${ }^{586}$

In Christianity baptism, i.e., being sprinkled with or immersed in baptismal water (which is the instrument of divine grace) is necessary for salvation. Baptism transforms the baptized person into a member of the Church and, above all, cleanses him from the 'maculation' of the guilt of original sin and frees him from all past personal guilt. ${ }^{587}$ The fecal comic burla, aimed here at the 'santo Sacramento del Baptismo,' is based on the double coding of 'relieve' (aliviarse) and on the fact that purification here is understood in purely bodily terms. When Ginés feels bad and suffers from a heaviness (malo y pesado) from which he wants to 'liberate' himself, and from which he seeks to 'relieve himself,' it is not the (physically invisible) burden of the original sin or personal guilt that 'oppresses him' and which would be taken from him with baptism, but pure physicality, for he is described as 'muy gruesso de carnes.' Therefore, if his desire for relief is purely physical in nature, his desire to become a Christian in the context of the subsequent representation of baptism implies a corresponding equation with regard to the causes of purification and the ritual of purification itself; the scene thus represents a crude ridiculing of this Christian sacrament. ${ }^{588}$

Although Lope's drama corresponds to the structural scheme of the martyr's vita, various elements are amplified or, conversely, minimized. The

586 Ribadeneyra, "La vida de san Gines” (cf. note 495), p. 360a.

587 See, e.g., Augustinus, Enchiridion de fide, spe et caritate 17, 64: “[...] baptismatis mun[us], quod contra originale peccatum donatum est, ut quod generatione attractum est, regeneratione detrahatur; et tamen activa quoque peccata, quaecumque corde, ore, opere commissa invenerit, tollit" [the gift of baptism is given us as an antidote against original sin, so that what is contracted by birth is removed by the new birth (baptism), and moreover, it also takes away actual sins as well that have been committed in thought, word, and deed] (Aurelius Augustinus, Enchiridion de fide, spe et caritate/Handbüchlein über Glaube, Hoffnung und Liebe [Latin-German], trans. and ed. Joseph Barbel, Darmstadt 1960, p. 120). Cf. as well on the issue of baptism altogether Thomas Aquinas, Summa theologica III $^{\mathrm{a}}$ q. 66 ("De sacramento baptismi"/'Of the Sacrament of Baptism'), esp. art. 1, 3, 7, 9 (Aquinas, Summa [Latin] [cf. note 347], vol. 29 [1935], pp. 147-199, esp. pp. 148-152, pp. 155-160, pp. 174-178, pp. 183-188; Aquinas, Summa [English] [cf. note 347], vol. 4, pp. 2373-2386, esp. pp. 2373 f., pp. 2375 f., pp. 2380 f., pp. 2382 f.).

588 The fact that Ginés is described here as corpulent represents another detail of the changes made in Lo fingido verdadero. Lope's Ginés is not only no longer the farsante as in Ribadeneyra's text, but a respected actor, manager and poet, and is described as galán instead of gruesso de carnes. 
miracle of the conversion of Ginés from an actor who uses his skills to mock Christians to a true Christian is a selective event in the hagiographical model. In Lope de Vega's drama, however, this miracle is not an isolated event but is foreshadowed and prepared for in the text. The gradual transition from the play to the real Christian is probably one of the most striking modifications of the Genesius-vita in Lo fingido verdadero. ${ }^{589}$ The Christian is a part that the actor Ginés is famous for playing convincingly and, one that he has already played numerous times before actually becoming a Christian. One could say that he has become a Christian by 'habitualization.' The concept of hexis - an ethical attitude achieved through habituation and practice - i.e. the idea that action results in conviction, has its origin in Aristotelian ethics ${ }^{590}$ and was adopted by scholasticism. ${ }^{591}$ This aspect of the play is relevant in light of the theological controversies being waged during this period. Hexis was in fact a central aspect of the Catholic doctrine of 'guiding' believers, and which Protestantism denied. According to the action-oriented religious education advocated by Catholicism, orthopraxis leads to right behavior. Action thus forms conviction - and not vice

589 The further aspects of the 'preparatory character' of the theologically complex drama already mentioned in the course of the outline of the plot will be discussed in more detail below. 590 Cf. Aristoteles, Ethica Nicomachea II, 1, 1103a 14-b 25 (as well as: II, 2-6, 1103b 26-1107a 23): "Excellence, then, being of two kinds, intellectual and moral, intellectual excellence in the main owes both ist birth and its growth to teaching (for which reason it requires experience and time), while moral excellence comes about as a result of habit [or custom] [ $\varepsilon \theta 0 c]$, whence also its name is one that is formed by a slight variation from the word for 'habit' $[\varepsilon \theta o c]$. From this it is also plain that none of the moral excellences arises in us by nature; [...]. [...] Neither by nature, then, nor contrary to nature do excellences [virtues] [ópetŕ] arise in us; rather we are adapted by nature to receive them, and are made perfect by habit. [...] [B]ut excellences we get by first exercising them, as also happens in the case of the arts as well. For the things we have to learn before we can do, we learn by doing, e.g. men become builders by building and lyre-players by playing the lyre; so too we become just by doing just acts, temperate by doing temperate acts, brave by doing brave acts. [...] Thus, in one word, states [characters] arise out of like activities. This is why the activities we exhibit must be of a certain kind; it is because the states [characters] correspond to the differences between these. [عँ $\xi$ เ ] It makes no small difference, then, whether we form habits of one kind or of another from our very youth; it makes a very great difference, or rather all the difference" (Aristotle, Nicomachean Ethics, trans. William D. Ross, rev. James O. Urmson, in: The Complete Works of Aristotle [cf. note 99], vol. 2, pp. 3718-4009, pp. 3746 ff.).

591 Cf. Thomas Aquinas, Summa theologica $\mathrm{I}^{\mathrm{a}}-\mathrm{II}^{\text {ae }}$ q. 49-55 (habitus); cf. i.a. esp. q. 51 a. 3; q. 52 a. 3; q. 55 a. 2; Thomas Aquinas, however, moreover, distinguishes between virtues 'acquired' through practice and repetition (virtutes acquisitae) and the virtues 'infused' by God (virtutes infusae) (cf. i.a. Summa theologica $\mathrm{I}^{\mathrm{a}}-\mathrm{II}^{\text {ae }}$ q. 51 a. 4; q. 63 a. 3, q. 65 a. 2) (Aquinas, Summa [Latin] [cf. note 347], vol. 11 [1940], pp. 3-117, esp. pp. 54-60, pp. 74 ff., pp. 107-110; Aquinas, Summa [English] [cf. note 347], vol. 2, pp. 793-822, esp. pp. 805 f., pp. 809 f., p. 820). 
versa, as Protestantism held. ${ }^{592}$ The concept underlying Lope's drama not only refers to a post-Tridentine framework, but also illustrates the instability of the border between truth and pretense and the potentially problematic differentiability of (still) 'play' and (already) 'seriousness' that is focused on in the comedia. ${ }^{593}$

In Ribadeneyra's Life of Genesius, Ginés tells of the 'miracle of his conversion performed by God,' his actual baptism which took place during the play which then causes him to address the emperor and the people in order to proclaim his new faith and attempt to convert his listeners. This last element is missing in Lope ("[...] digo, que de oy mas confiesso a Iesu Christo por verdadero Dios, y os amonesto que todos hagais lo mismo y que salgais de las tinieblas de que yo he salido, para que euiteis los tormentos que yo he euitado." ${ }^{594}$ : When they wanted to sprinkle him (on stage) with the baptismal water and asked him whether he believed in what the Christians believed, he saw, as he looked up, a hand from heaven laying down on him and angels with a fiery face reading a book about all the sins committed during his life, and then promising him deliverance from these sins through baptism, if he truly wished it. He did ask for it and, as the water poured down upon him, he had seen the entries in his book of sins immediately deleted. The angels admonished him to preserve his newly established purity and to no longer stain his soul with sin. He continues by saying that he had sought to please the earthly ruler, but that the

592 Part of the fundamental delineations of the Reformation from the Catholic Church's understanding and practice of faith is the negation of the 'justification by works,' which it replaces with the principles sola gratia and sola fide. Cf., e.g., Martin Luther, "Eynn Sermon von dem Ablasz unnd gnade" (1518), in: [Martin Luther], D. Martin Luthers Werke: Kritische Gesamtausgabe, 120 vols. (4 sects.), Weimar 1883-2009, sect. 1, vol. 1 (1883), pp. 243-246 (for instance: "Es ist eyn großer yrthum, das yemand meyne, er wolle gnugthun vor seyne sund, so doch got die selben altzeit umbsunst auß unschetzlicher gnad vortzeyhet, nichts darfur begerend, dann hynfurder woll leben" [p. 245, 21-23]). For the Catholic position, cf. the 'Decree on Justification' adopted in the 6th session of the Council of Trent in 1547 (Concilium Tridentinum, Sessio VI “Decretum de iustificatione”/Session 6, 13 January 1547 'Decree on justification' [Canones et Decreta/Canons and Decrees (cf. note 374), pp. 671-683], esp. Cap. XVI "De fructo iustificationis, hoc est, de merito bonorum operum, deque ipsius meriti ratione"/ chap. 16 'On the fruit of justification, namely merit from good works, and on the nature of that merit' [pp. 677 f.] and Canon XXXII [p. 681]).

593 It needs to be noted that in the 'real' Spain of that period it also served as an argument for perfidious denunciation and persecution. Conversos and moriscos (up to their expulsion in 1609) were always vulnerable to the allegation (and its life-threatening consequences) that they were only 'pretending' to follow the Catholic rites. This aspect will be discussed in more detail in the context of the analysis of Cervantes' interlude (Chapter 5).

594 Ribadeneyra, "La vida de san Gines” (cf. note 495), p. 360b. 
ruler of heaven had looked at him with a benevolent gaze and welcomed him into his grace; he had wanted to make people laugh and thereby brought joy and jubilation to the angels. ${ }^{595}$

Lope's dramatization of these aspects - request for baptism, pretend baptism, and real baptism, appearance of the angels, change from 'earthly' to 'heavenly' actor - are developed in a complex way and in connection with the systematic blurring of fingido and verdadero. The actual performance is preceded by a rehearsal scene. While Ginés rehearses the role of the Christian martyr, he asks - as part of the play - for baptism. Heavenly music sounds, the sky 'opens' and the heavenly inhabitants become visible. This divine intervention, however, can only be seen by the spectators/readers. Ginés repeats his request for baptism and hears a voice that promises him that his acting is not in vain and promises him salvation. Ginés is unable to classify what he perceives and his subsequent inner reaction. He is not sure whether he was actually called by an angel or whether it was an actor of his theater company who spoke to him as part of the rehersal, or whether it was simply a deception of the senses. This is further complicated by the conversation with Fabio. At the end of this prelude, it is not possible to determine whether Ginés already sees himself as a Christian or not. The subsequent 'play within the play' is characterized by a great fragility of the levels of illusion. When Ginés asks for baptism, his fellow players notice the deviation from the script, but attribute this to his penchant for improvisation. An angel appears above the stage and asks Ginés to come to him in order to baptize him. Ginés goes. The baptism is presented 'vividly' on the upper stage level (angels with baptismal utensils become visible; music sounds). From this point on, Ginés integrates metaphors of acting within his speeches about his conversion and his desire to die the martyr's death (e.g., God from now on provides the cues, he had so far played a wrong role, now he is part of the divine group of actors). The inner spectators comment on Ginés' performance as unique and indistinguishable from reality, whereas the other

595 "Pero al mismo punto q[ue] querian echar el agua del Bautismo sobre mi cabeça, y me preguntaro[n] si crehia lo que los Christianos creen: leuantando los ojos en alto, vi vna mano que baxaua del cielo sobre mi, y Angeles con rostros de fuego, que en vn libro lehian todos los pecados que en mi vida cometi. Dixeronme los Angeles: Destos pecados seras libre con esta agua con que quieres aora ser bañado, si de veras y de todo coraçon lo deseas. Yo assi lo desee y pedi, y luego cayò sobre mi el agua, vi la escritura del libro borrada, sin que en el quedasse señal alguna de letra. Dixeronme los Angeles: Ya has visto como has sido limpio desta culpa y manzilla, procura conseruar la limpieza que has recebido, y no manchar mas tu alma con pecado. [. . .] Yo procurè agradar al Emperador de la tierra, y el Emperador del cielo me mirò co [n] ojos benignos, y me admitiò en su gracia: quise causar risa a los hombres, y causè alegria y regozijo a los Angeles [...]” (ibid.). 
actors are confused. When Fabio enters the stage in the role of an angel in order to perform the scene of Ginés' baptism, the confusion on the stage now reaches the internal audience. They all think that it was Fabio who had played the angel. Fabio vehemently denies this, and Ginés emphasizes the authenticity of his conversion and baptism, and the reality of the angel. Diocleciano is not immediately convinced. Only when Ginés is asked whether he was playing or speaking in earnest, and after Ginés' mockery of the gods and the emperor, does he condemn him and declare the performance to be over. The clarification of the question of who was the angel who appeared is not pursued by either the internal audience or the fellow actors.

In Lo fingido verdadero, the (second) 'play within the play' is a tragedia that deals with the martyrdom of a Christian (in contrast to the hagiographical model version), i.e. the action laid out in this inner play already anticipates the subsequent action in the frame-play. In this sense, it works as a dramatic mise en abyme. ${ }^{596}$ Structures and content-related moments that generate a mirror effect and the alternation of fingido and verdadero are elaborated in manifold

596 More precisely, one could even classify it as a 'mise en abyme retro-prospective' (as the change of Ginés from an acting to a 'true' Christian is prepared in terms of structure and in terms of content). The device of mise en abyme - albeit in narrative texts - was studied and developed by Lucien Dällenbach (The Mirror in the Text [Le récit spéculaire: Essai sur la mise en abyme, Paris 1977], trans. Jeremy Whiteley and Emma Hughes, Chicago 1989, esp. pp. 41-113, here p. 60). George Forestier discusses the relation between 'theater within theater' and mise en abyme in the introduction to his seminal study on the 'play within the play' in 17th-century French theater: "La notion de théâtre dans le théâtre est [. . .] fréquemment confondue avec celle de mise en abyme. En fait la mise en abyme, qui suppose que l'œuvre se mire dans l'œuvre, est une figure littéraire qui ne ressortit pas exclusivement au domaine du théâtre, et qui d'ailleurs, est fort à la mode dans la littérature romanesque du XXe siècle, et particulièrement dans le roman français des vingt dernières années. En outre, la mise en abyme proprement théatrale est loin de correspondre exactement à la notion de thêâtre dans le théâtre. Celle-ci désigne un dédoublement structurel, et la première un dédoublement thématique, c'est-à-dire une correspondance étroite entre le contenu de la pièce enchâssante et le contenu de la pièce enchâssée. Il va sans dire qu'un petit nombre de pièces seulement présentent un tel jeu de miroir [...]. [...] [L]'on ne s'étonnera pas constater que les pièces les plus passionantes de notre corpus associent cette figure à la structure du théâtre dans le théâtre" (Forestier, Le théâtre dans le théâtre sur la scène française du XVII siècle [cf. note 3], p. 13; the concrete application with reference to Dällenbach's terminology on pp. 149-171). Furthermore, Nolting-Hauff draws attention to the fact that in Lope's play some of the characteristic plot elements of the martyr's life genre, such as the capture of the protagonist and the confrontation between the martyr and the supreme persecutor of Christians, are implemented in the inner play in an even more distinctive form than in the outer play ("Lo fingido verdadero" [cf. note 491], pp. 73 f.; “[...] [Ei]nzelne typische Handlungsmomente der Märtyrervita, wie die Gefangennahme des Helden und die Konfrontation zwischen dem Märtyrer und dem 
ways in Lope's comedia. It is significant that Lope, in this dramatic adaptation of the Genesius legend, has Ginés enter the stage twice for the entertainment of the imperial audience. Note the structural parallels between the second and third jornada in the context of the inner plays: Ginés prepares for his role ('un amante' or 'el cristiano bautizado'), converses with a fellow actor (Pinabelo in the second, Fabio in the third act), there is a short conversation among the inner audience, performance of a piece of music, performance of the loa, performance of the actual comedia; irritations during the performance, blurring of the boundaries between play and reality resulting in Diocleciano's termination of the performance. The first 'play within the play' is a comedia de amor or comedia de celos. This serves to introduce the theme of love in general, and posit the transience of corporal love ${ }^{597}$ thus preparing the way for the message of eternal love that is the focus of the third act. Ginés' conversion to Christianity (on the internal level of play and on the internal level of reality) is an expression of both the love of God and caritas as central concept of Christianity (mentioned explicitly in Ginés' closing words). The change from fingido to verdadero is, in this case, the transformation of amor fingido, false worldly love, into amor verdadero, true Christian love. Analogous to the change from the erotic-earthly love to the love of God, the moment must also be seen in relation to gracia (grace). Ginés initially performs to gain the favor of Diocleciano, the earthly ruler. After his conversion, however, he strives instead for Divine Grace, which becomes the 'true' favor he seeks. He acquires the grace of the heavenly ruler by his acting/actions (without knowing it himself).

Regarding the thematization of theater, ${ }^{598}$ Lope's play not only contains two different 'plays within the play' in which the boundaries between theatrical fiction and reality become blurred, it includes discussions about the composition and performance of theatrical works that relate to contemporary debates

obersten Christenverfolger, [werden] im Binnenstück sogar in markanterer Form aktualisiert als im Außenstück").

597 In addition to the love constellation on the first play level between the actors Ginés, Marcela, and Octavio, which is closely linked to the constellation developed on the second play level between Rufino (Ginés), Fabia (Marcela), Octavio (Octavio), there is also the love between Diocleciano and Camila. In this context, it is worth drawing attention again to the comparison of love as 'the cruelest of all beasts' (see vv. 2237-2252).

598 That is, in a poetological perspective; the aspect of the 'theater of the world' will be discussed below. Lo fingido verdadero is discussed in terms of 'metadrama' i.a. by Canonica, "De la ficción de la verdad a la verdad de la ficción" (cf. note 494); Canning, "Lo fingido verdadero as Metaplay” (cf. note 494); Dixon, "YYa tienes la comedia prevenida...” (cf. note 493); Fischer, "Dramatization of the Theatrical Experience" (cf. note 494); D’Artois, "El teatro en el teatro en Lo fingido verdadero" (cf. note 494). 
on the topic (cf. in the first act between Carino and Ginés, vv. 459-545; in the second act between Ginés, Diocleciano and Camila, vv. 1204-1265). Furthermore - with regard to the complex and to some extent 'open' composition of the play -, it should be noted that Lope used typical elements from several sub-genres of comedia, such as comedia histórica (Diocleciano's rise to power), comedia de capa y espada/de enredos and comedia de honor (en miniature, so to speak: the Carino episode in the first act), comedia de capa y espada/ de enredos (in the second act in a potential form), and comedia de santos (the martyr play of Ginés). ${ }^{599}$

The theme of the play, as reflected in its title, is not only played out in Ginés' transformation from an actor playing a Christian to a true Christian, the whole play, including the political (first jornada) and the love (second jornada) subplots, in fact destabilizes the border between fiction and reality. Diocleciano's rise to power (and the related relationship between Camila and Diocleciano) is also presented as closely linked to the aspect of burlas verdaderas. Diocleciano 'realizes' Camila's statement, made in jest, that he would become Roman emperor by killing a boar, by stabbing Consul Apro. Camila, for her part, 'realizes' Diocleciano's promise, also made in jest, to reward her for the bread she gave him, by demanding this from him when he became emperor. Camila's remark: 'Las cosas que ordena el cielo / en sus secretos divinos, / van por tan raros caminos, / que no los entiende el suelo' (vv. 1110-1114), encapsulates other events of the first act as well. While essentially historically correct, the experience of their extreme condensation and repetition gives them a 'didactic' pointedness. ${ }^{600}$ The violent death of Apro is the fourth in a 'series' ${ }^{\text {'601 }}$ of 'sudden' deaths of Roman rulers (or self-proclaimed aspirants as in Apro’s case). Emperor Aurelio is struck by lightning, Carino is stabbed by Consul Lelio, Numeriano is murdered by Apro. The events are contextualized ideologically and thus become anticipatory in Carino's dying words, where he refers to the 'world as a stage' on which he had played a role that has now come to an end.

599 Cf. Canonica, "De la ficción de la verdad a la verdad de la ficción" (cf. note 494), pp. 102-109; Nolting-Hauff, "Lo fingido verdadero" (cf. note 491), p. 83; Laemmel, "Zur Adaptation einer 'comedia de santo' in Frankreich" (cf. note 494); cf. as well Bryans, "Fortune, Love and Power in Lope de Vega's Lo fingido verdadero" (cf. note 494), who examines the comedia in terms of fate, love, and power on the basis of the sub-genres comedia de tiranos and comedia de mártires that are merged in it.

600 For this aspect, see as well Nolting-Hauff, “Lo fingido verdadero" (cf. note 491), pp. $74 \mathrm{ff}$. 601 N. M. Valis regards these series of scenes even as a 'dance of death' ("Rotrou and Lope de Vega: Two Approaches to Saint-Genest” [cf. note 494] pp. 49 f.). 
The merging of fiction, representation, and reality, the difficulty of an adequate distinction between appearance and being on the one hand, and the transformation of fiction into reality on the other hand, is inherent in the actor Ginés. In his speech on the art of acting, he postulates that 'representar' was only possible if one had oneself experienced the emotions being portrayed. In the moment of performance one had to access these emotions and experience them as if they were real. ${ }^{602}$ As Fischer notes, "This is reminiscent of what has become the Stanislavsky approach of acting [...]." ${ }^{603}$ In the course of the play, there are several references to the extreme intensity of Ginés' acting (e.g.: '[. . . imitas con extremo / un rey, un español, un persa, un árabe, / un capitán, un cónsul; mas [. . .] todo / lo vences cuando imitas un amante.' vv. 1266-1269; 'La imitación / del cristiano bautizado, / [...] es un extremo en ti’ vv. 2312 ff.; “DiocL.: Bien

602 Let us recall the passage: 'El imitar es ser representante; / pero como el poeta no es posible / que escriba con afecto y con blandura / sentimientos de amor, si no lo tiene, / y entonces se descubren en sus versos, / cuando el amor le enseña los que escribe, / así el representante, si no siente / las pasiones de amor, es imposible / que pueda, gran señor, representarlas; / una ausencia, unos celos, un agravio, / un desdén riguroso y otras cosas / que son de amor tiernísimos efectos, / harálos, si los siente, tiernamente; / mas no los sabrá hacer si no los siente' (vv. 1270-1283; cf. also the subsequent explanation of this method in vv. 1292-1351). In his Arte nuevo, Lope writes about the art of writing plays and not the art of acting. It says there however, similarly: "Si hablare el rey, imite cuanto pueda / la gravedad real; si el viejo hablare, / procure una modestia sentenciosa; / describa los amantes con afectos / que muevan con extremo a quien escucha; / los soliloquios pinte de manera / que se transforme todo el recitante, / y con mudarse a sí, mude al oyente" (vv. 269-276 [Lope de Vega, Arte nuevo de hacer comedias (cf. note 503), p. 146; my italics]). Josef Oehrlein who, apart from Lope's instructions in the Arte nuevo, refers here to the 'catalogue' of acting skills articulated by the protagonist in Cervantes' Pedro de Urdemalas (1615) (act 3, vv. 768-801), summarizes this with the statement, '[...] that the actor literally has to play himself into the role' (" [...] daß sich der Akteur regelrecht in die Rolle hineinspielen müsse”). And he continues: 'The text provides impulses which are emotionally charged and intensified by linguistic and gestural expression, to such an extent that the actor makes the stage role transform into himself, that is, that he no longer merely plays its behaviours and emotions, but experiences them, so to speak' (“[...] Vom Text gehen Impulse aus, die durch sprachliche und gestische Gestaltung verstärkt, emotional aufgeladen werden, und zwar in einem solchen Maß, daß sich der Schauspieler die Bühnenrolle anverwandelt, das heißt deren Verhaltensweisen und Affekte nicht mehr nur spielt, sondern sie gewissermaßen durchlebt") (Josef Oehrlein, Der Schauspieler im spanischen Theater des Siglo de Oro (1600-1681): Untersuchungen zu Berufsbild und Rolle in der Gesellschaft, Frankfurt am Main 1986, p. 125; cf. in total pp. 123-128 ["Imitación de la naturaleza: Die Kunst des Schauspielers”], on Lo fingido verdadero, pp. 126 f.; regarding contemporary Spanish acting theory, cf. Evangelina Rodríguez Cuadros, Le técnica del actor español en el Barroco: Hipótesis y documentos, Madrid 1998, esp. pp. 125-418, here p. 196).

603 Fischer, "Dramatization of the Theatrical Experience" (cf. note 494), p. 161; see as well Egginton, How the World Became a Stage (cf. note 494), p. 71. 
representa. MAX.: En extremo" vv. 1958) ${ }^{604}$ and his talent for improvisation (cf. vv. 2705-2711). In the second act, Ginés takes on the role of a 'love maniac.' During his preparation he emphasizes the authenticity of his emotions, and refers to the reality of his 'imitation' ('[. . . imito lo que siento; / pero en tanta propiedad / no me parece razón / que llamen imitación / lo que es la misma verdad;' vv. 1301-1305). He will perform 'his comedia,' he announces to Diocleciano ('Haré la mía' v. 1263). The play’s inner reality (the lovers Octavio and Marcela, Ginés' jealousy) and the 'play within the play' are closely interwoven with one another and influence each other. But Ginés' jealousy of Octavio and his desire for Marcela, passionate before, during, and immediately after the aborted comedia de celos, are no longer of any relevance to him a short time later when the couple returns, as Ginés emphasizes at the beginning of the third act. This, however, prefigures the fact that he will soon - without being aware of this himself - turn towards 'true' love. When, before his performance of the "[ . . ] comedia / del cristiano bautizado" (vv. 2390 f.), he devotes himself to the role of the Christian martyr, he seems to be 'carried away by his character' through his intense acting and again premises acting as: '¿qué mejor puedo imitar / si fuera el cristiano mismo / que se pretende salvar?' (vv. 2476ff.) so that he asks for baptism and hears a voice promising him salvation for his good acting. But for him, the fact that this was indeed a call from heaven, an angel, is only one possible explanation. During the performance of the inner play, as one could read it against the backdrop of Ginés' conception of acting, the rapture and ecstasy of acting makes the actor indistinguishable from the character he portrays; imitation slips from the actor's control and becomes reality. ${ }^{605}$ Ultimately, Ginés does

604 Cf. the entry "EXTREMO" in the Diccionario de Autoridades (Real Academia Española, Diccionario de la lengua castellana, en que se explica el verdadero sentido de las voces, su naturaleza y calidad, con las phrases o modos de hablar, los proverbios o refranes, y otras cosas convenientes al uso de la lengua [= Diccionario de Autoridades], 6 vols., Madrid 1726-1739, vol. 3 [1732], pp. 700b-701b, here p. 701b).

605 Cf. Oehrlein's interpretation: 'The end, which Ginés approaches as a consequence of his extremely authentic representation of feelings, may correspond to the convention of the legend, but it also results quite logically from the postulate that the actor must fully feel the emotions himself, which correspond to the behavior of the stage character: Ginés is so absorbed in a Christian's world of feelings that he himself becomes a Christian and even accepts martyrdom for it' ("Das Ende, dem Ginés als Konsequenz aus seiner äußerst wahrhaften Gefühlsdarstellung entgegengeht, mag zwar der Konvention der Legende entsprechen, es ergibt sich aber auch ganz folgerichtig aus dem Postulat, daß der Schauspieler die Emotionen selbst voll und ganz empfinden müsse, die dem Verhalten der Bühnenfigur entsprechen: Ginés steigert sich so sehr in die Empfindungswelt eines Christen hinein, daß er selbst zum Christen wird und dafür auch den Märtyrertod in Kauf nimmt”) (Der Schauspieler im spanischen Theater des Siglo de Oro [cf. note 602], p. 126). 
not die in the framework of the play, but actually dies a martyr's death. Nevertheless, he has not only become a 'real Christian' through his acting, decisive in this are the work of divine grace and the sacrament of baptism. ${ }^{606}$ Against the backdrop of contemporary controversies over the legality (licitud) of the theater and, in connection with this, the role of the actor, ${ }^{607}$ Lope appears to claim here that rather than being evil, acting can lead to good, such as Ginés' conversion.

In Lope's drama, the 'levels of reality' interplay against each other, leading to different interpretations of what is perceived (on the part of the actors, on the part of the spectators within the play, on the part of the viewers/readers). What is explicitly declared fictitious becomes reality (in an explicitly fictious framework: comedia): the representation of a Christian martyr is transformed into the object of the representation. Ginés professes Christianity and dies the martyr's death. (Play-internal) reality is transformed into fiction, which in turn has a retroactive effect on (play-internal) reality: Ginés, who is in love with Marcela and jealous of Octavio, writes a comedia on this subject, acted by those involved (the roles of Fabia/Octavio/Rufino) that he hopes will influence the 'real' relationships. This is an aspect that the viewers/readers are aware of, but not the inner audience. In the course of the performance, however, the fiction becomes fragile as Ginés 'breaks character.' The escape of Fabia (played by Marcela) and Octavio (played by Octavio), which is part of the play, turns into a real (at least temporary) disappearance of Marcela and Octavio. This influences the further progress of fiction: improvisation is necessary on stage, which

606 According to Catholic dogmatics of post-Tridentine character, 'baptism works by itself' (ex opere operato). Cf. the 'Decree on the Sacraments' passed by the Council of Trent at its 7th session (1547): Concilium Tridentinum, Sessio VII, 3 mart. 1547 "Decretum primum [De sacramentis]"/Session 7, 3 March 1547 'First decree [On the sacraments]' (Canones et Decretal Canons and Decrees [cf. note 374], pp. 684-689), "Canones de sacramenti in genere”/“Canons on the sacraments in general' (pp. 684-685), Canon 8 "Si quis dixerit, per ipsa novae legis sacramenta ex opere operato non conferri gratiam, sed solam fidem divinae promissionis ad gratiam consequendam sufficere: a[nathema] s[it]"/ If anyone says that grace is not conferred by the sacrament of the new law through the sacramental action itself, but that faith in the divine promise is by itself sufficient for obtaining the grace: let him be anathema' (p. 685).

607 Regarding this, see Rodríguez Cuadros, Le técnica del actor español en el Barroco (cf. note 602), pp. 295-312; Oehrlein, Der Schauspieler im spanischen Theater des Siglo de Oro (cf. note 602), pp. 144-151; Wolfram Nitsch, Barocktheater als Spielraum: Studien zu Lope de Vega und Tirso de Molina, Tübingen 2000, pp. 44-52; Poppenberg, "La licitud del teatro" (cf. note 494); Manfred Tietz, "Die Debatte um die 'moralische Zulässigkeit des Theaters' im spanischen 17. Jahrhundert und ihre Folgen," in: Sybille Große/Axel Schönberger (eds.), Dulce et decorum est philologiam colere: Festschrift für Dietrich Briesemeiser zu seinem 65. Geburtstag, Berlin 1999, pp. 705-732. 
then leads to an interaction between the separate areas 'stage' and 'audience' and finally brings the performance to a premature end. It also affects the events and the real-life relationships: Marcela and Octavio get married. Thus Ginés' attempt in the second act to influence reality by means of fiction, i.e. to strain the bonds of love between Octavio and Marcela in favor of his own (re)desired love relationship with Marcela, fails. Using acting to influence reality fails as long as the goal is a 'false' one, that is, earthly-erotic love. As soon as the goal is changed, acting does indeed bring about the desired end, even though the 'right' goal, the love of God, is not yet obvious to the actor himself. Ginés plays the role of a Christian and becomes a Christian himself during this 'play' - lo fingido verdadero - restrospectivly recognizing the 'truth' of what was initially burla to him. This structure implies that the 'avoidance of the wrong,' of sin, 'automatically' leads to right, even if one does not yet know it or does not yet consciously strive for it. In the context of a period when long-held beliefs were being questioned and perhaps perceived as fragile, this must have been seen as the 'great promise' of Lope's play.

One of the basic assumptions of Pyrrhonian skepticism outlined in the first ten tropes of the Hypotyposeis is the unreliability of sensory perception. The fact that perception is relative, that the world is not necessarily as it seems to be to us, stems from a skeptical point of view that maintains that no certain statements can be made about reality. Skepticism challanges the difference between being and appearing, and asks critical questions about claims of knowledge as well as practice: how is one to behave in the face of not being able to know? Lo fingido verdadero explores the fragile boundary between being and appearing and the difficulty of distinguishing between fingido and verdadero through the medium of acting. Theater and acting serve as a metaphor for doubt about the perception of reality, but only to a certain extent. Within Orthodox Christianity, which views the physical world as false and transitory and the afterworld as true and eternal, the theater also functions as a metaphor for the illusory nature of the earthly world as a whole. In this sense, Lope's comedia represents the first Spanish dramatization of the concept of theatrum mundi. This topos of life as a play and the world as a stage was already used in antiquity, but was rediscovered and widely explored in Baroque literature. ${ }^{608}$ The best known example of this, Calderón de la Barca's auto sacramental El gran teatro del mundo, first

608 For the genesis of this topos, cf. Ernst Robert Curtius, European Literature and the Latin Middle Ages, trans. Willard R. Trusk, Princeton, NJ 1990, pp. 138-144; Antonio Vilanova, "El tema del gran teatro del mundo," Boletín de la Real Academia de Buenas Letras de Barcelona 23 (1950), pp. 153-188. 
printed in 1655 , probably originated in the 1630s, more than twenty years after Lope's drama. ${ }^{609}$

Lo fingido verdadero sets up this image of the world as a stage on which humans play a role assigned to them, with God in the role of director, and the earthly world as theater with the true eternal life coming after death from the very beginning. Celio tells Carino that the only difference between him and actors was the time limitation of the role. His comedia and thus his role as ruler lasted his whole life and ended with his death, he was 'de rey vestido / hasta la muerte' (vv. 368 f.). Carino is angry about this comparison, declaring that he and his position as ruler was not fiction, but true and valid beyond death (cf. vv. 392-405). But when he dies violently at the end of the scene, he, embraces the insight that he has only played a 'role' on the stage of the world, that the tragedia was over now, the costume had to be taken off, and that his successor shall play the 'role' better than him. In the third act, the 'theater of the world' metaphor is taken up again by Ginés in the 'play within the play' and, as shown above, used and expanded upon several times. ${ }^{610}$ To illustrate this, the following passages are quoted again highlighting the relevant metaphors:

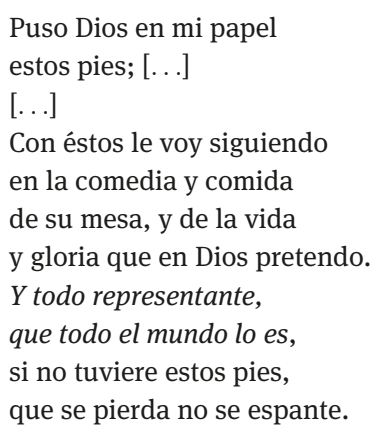
(vv. 2782-2793; my italics)

609 The fact that Lo fingido verdadero is both the first dramatic interpretation of the 'world theater' theme in Spanish literature and an important precursor to Calderón's auto of the same title, is already indicated by Vilanova ("El tema del gran teatro del mundo" [cf. note 608], p. 172); cf. as well Dixon, “Ya tienes la comedia prevenida...”' (cf. note 493), p. 59. A more detailed comparison regarding the treatment of the metaphor in Lo fingido verdadero and Calderón's allegorical drama, however, will not be carried out here (on Calderón's play El gran teatro del mundo, see below note 614).

610 'Representé mi figura: / César fui, Roma, rey era; / acabóse la tragedia, / la muerte me desnudó: / sospecho que no duró / toda mi vida hora y media. / Poned aquestos vestidos / de un representante Rey, / pues es tan común la ley / a cuantos fueron nacidos, / adonde mi sucesor / los vuelva luego a tomar, / porque ha de representar, / iquiera el cielo que mejor!' (vv. 641-654). 




At the end of the comedia, the protagonist, about to die, addresses the Roman people and reflects on his conversion, contrasting the 'wrong role' and the 'wrongly oriented play' to the now 'right' one, and on his impending earthly death, which marks the end of deception:



(vv. 3104-3121)

The theatrum mundi metaphor thus forms the final argument of the drama. ${ }^{611}$ This implies in consequence that illusion and reality can only be distinguished by dogmaticism. Those who believe in nothing are trapped in skepticisim's

611 Gaston Hall sees in Ginés' final monologue the articulation of a Molinist position for the drama: "Toute la structure providentielle de la tragi-comédie est éclairée retrospectivement par ce 
radical doubt and thus miss the point of their lives. ${ }^{612}$ In Lope's drama, no epistemological answer is suggested to skepticism's challenge regarding the indistinguishability of illusion and reality, which in the play is based on theatrical illusion and the destabilization of the boundary between appearance and being at all levels of the plot. Instead the belief in the right and the corresponding right action are at the center of the message. Certainty does not exist in this world. The ultimate knowledge of the world lies only with God. Only the right faith and good acting of the (right) role offers man a reliable orientation. It should be pointed out again, however, that the 'theater of the world' metaphor in Ginés' final monologue is not quite consistently formulated, insofar as the image area of the theater also serves as a paraphrase of life after death, which would have to be understood as reality or truth and not as fiction: 'Mañana temprano espero / para la segunda parte' (vv. 3120 f.; my italics). In the 'sequel' of the comedia divina, in which Ginés acts as part of God's compañia and becomes the mejor representante by his martyrdom, ${ }^{613}$ a new life awaits him, that is: the eternal reward for his good (resp. right) acting ('voy al cielo a que me paguen' vv. 3115). ${ }^{614}$ The 'theological inconsistency'

rappel de la doctrine de la grâce en anticipation des mérites, qui mériteraient à leur tour le salut: la grâce post praevisa merita préconisée par Molina dans son traité De concordia (1588)" ("Illusion et vérité dans deux pièces de Lope de Vega” [cf. note 494], p. 48). Forestier, who, moreover, emphasizes Lope as the inventor of the method of 'play within the play' in Spain, also emphasizes the Christian character of the play's 'theater of the world' metaphor and, furthermore, pointedly expresses the significance that this context entails for the conception of 'theater as such': "En effet, si le monde est théâtre, le théâtre proprement dit s'exprime en termes de théâtre dans le théâtre: le théâtre est inclus dans le théâtre du monde. On comprend qu'à un moment où l'inclusion d'une action dramatique dans une autre était, du point de vue technique, un problème à peu près résolu, la fortune de la conception philosophique du petit théâtre dans le grand théâtre ait pu influer fortement sur le rapide développement du procédé. Il est tout à fait significatif que l'inventeur espagnol du procédé, Lope de Vega, ait choisi de l'utiliser dans une pièce où il illustrait la version chrétienne du thème, Lo fingido verdadero (l'histoire de saint Genest)" (Le théâtre dans le théâtre sur la scène française du XVII ${ }^{e}$ siècle [cf. note 3], p. 39; italics in the original).

612 The best example of this would be Shakespeare's Hamlet (see chap. 2 of this study).

613 Regarding this, see again, e.g., vv. 2782-2793; vv. 2966-2979; vv. 3000-3005; vv. 3053-3059.

614 Comparatively, Calderón's auto sacramental about 'the great theater of the world,' also lacks a clear (metaphorical) demarcation between the realms of life in this world and life beyond. EL MUNDo instructs the characters that have left the stage (of life), saying: "al teatro pasad de las verdades, / que este el teatro es de las ficciones" (Calderón, El gran teatro del mundo, vv. 1390 f.). Not only earthly life, but also what follows after its end is denoted as 'theater.' The former is called 'theater of fictions,' and the latter is not simply opposed to it as 'reality,' but represents its continuation as a 'theater of truth.' After the performance, the end of the play within the play, 'World' takes away all 'costumes and props' from the characters, they are told to leave behind all the earthly things, which are only borrowed (cf. "MunDo: [...] deja, 
("theologische Inkonsistenz") arising in the final formulation of the theatrum mundi metaphor, which was not untypical for Lope's dramatic works, could, according to Nolting-Hauff, 'be ascribed to the subjective perspective of the protagonist obsessed with theater or to a certain momentum of its own in the theater-concetto' (“[...] [kann man] der subjektiven Perspektive des theaterbesessenden Protagonisten oder einer gewissen Eigendynamik des TheaterConcetto zuschreiben"). ${ }^{615}$ Simerka, on the other hand, sees in Ginés' final words an "undermin[ing] [of the] orthodox theological message [of the play]":

[...] [T]he many layers of reflexivity present in th[is] play[s] stimulate critical reflection concerning doubt and knowledge in response to the self-conscious staging of religious themes. The atmosphere of uncertainty concerning where performance ends and true existence begins is prominent in the final lines of the [...] play[s]. Theatrical metaphores are pervasive even in the dying words of the Lope's martyr, who refers to earthly life as a "human comedy" and names afterlife a "sequel". [...] [T]he linkage of the most important event of Christian dogma with theatricality - and hence pretense - serves to undermine the orthodox theological message. The ubiquity of self-conscious questioning of perception, reality and illusion throughout this drama paves the way for a heterodoxical interpretation of the concluding lines. ${ }^{616}$

While Simerka here notes the destabilization of the border between appearing and being, the staged blurring of fiction and reality (which is on a metaphorical

suelta, quita la corona; / la majestad, desnuda, pierde, olvida. (Quítaselo.) / Vuélvase, torne, salga tu persona / desnuda de la farsa de la vida. / [. . . / REY: ¿Tú no me diste adornos tan amados? / ¿Cómo me quitas lo que ya me diste? / Mundo: Porque dados no fueron, no, prestados / sí, para el tiempo que el papel hiciste” vv. 1290-1301). Excluded from this, however, are the 'good works,' as EL MUNDO addresses LA DISCRECIÓN with the words "No te puedo quitar las buenas obras, / estas solas del mundo se han sacado" (vv. 1377 f.). They are the link between earthly existence and the so-called 'last things.' Man's actions on earth, or rather, on the level of argumentation of the allegorical play: the way of fulfilling, playing the assigned role during the performance of the comedia with the significant title "Obrar bien, que Dios es Dios" has an impact on the salvation of the soul. Thus, what becomes quite obvious here are CounterReformation Catholicism's central arguments of liberum arbitrium (the baptized person, in the state of grace bestowed upon him, is able to decide for or against 'the right thing') and opera meritoria. (Used edition: Pedro Calderón de la Barca, El gran teatro del mundo/Das große Welttheater [Spanish-German], ed. and trans. Gerhard Poppenberg in coop. with HerleChristin Jessen and Angela Calderón Villarino, Stuttgart 2012).

615 Nolting-Hauff, "Lo fingido verdadero" (cf. note 491), p. 83. In contrast to Calderón, the qualities in Lope would consist not so much 'in the strict subordination of all details to a unifying concept,' but primarily 'in the variety of ideas and artistic means' (ibid. “[. . .] in der strengen Unterordnung aller Einzelheiten unter ein vereinheitlichendes Konzept [...]”; “[...] in der Vielfalt der Einfälle und der künstlerischen Mittel”).

616 Simerka, "Metatheater and Skepticism" (cf. note 2), pp. 68 f. (The interpretation refers to both Genesius-dramas, Lope's play and Rotrou's Le Véritable Saint Genest). 
level - in Ginés' final words - maintained until the end), and its affinity with the discourse of skepticism, she places it in a different context of interpretation. In the final scene, she says, "the precarious relationship between illusion and knowledge" was of particular importance. Since the audience was always aware that the "corpse" would return after the fall of the curtain, the death onstage was "the most metatheatrical of dramatic moments." ${ }^{617}$ It was, furthermore, "a special form of the "play within the play"."618 According to Simerka, its extreme and melodramatic representation, as for example in Lope's drama, was "an integral part of reflexivity," since, according to convention, one would expect such a spectacle, but "the unreality of the scenes ma[de] it easier to confront death." 619 Through the martyrs' heroic confirmation of the conviction of faith, the martyr's death on stage was "meant to encourage others to accept th[eir] new faith and[, because of the value of the ultimate reward,] profess it despite the consequences." ${ }^{620}$ The repetition of the theatrum mundi motif was all the more significant inasmuch as the "martyrdom of the persecuted believer" was staged. Simerka considers the (meta-)dramatic modeling of the Genesius legend in Lope de Vega (as well as in Rotrou) as a "radical affirmation of the skeptical mode of thought." She concludes that:

617 P. 69 (in reference to Harry Berger, Imaginary Audition, Berkeley, CA 1989, p. 98; subsequently [p. 69 ff.] to the study: Richard K. Sanderson, "Suicide as Message and Metadrama in English Renaissance Tragedy,” Comparative Drama 26 [1992], pp. 199-217, here pp. 201-210, whose observations on stage death in Early Modern revenge drama she transfers to the martyrdom-scene in Lope's comedia [and Rotrou's tragédie]).

618 Ibid.

619 P. 70. According to Simerka, in reference to a study on metatheatrical aspects of death on stage in English Renaissance drama (see above, note 617), the use of the theatrum mundimetaphor in death scenes constituted the main characteristic of the Early Modern 'revenge tragedy,' where "suicide and epistemological concerns" were sometimes "juxtapose[ed].” Moreover, death on stage was also "a form of ritual of death and rebirth." The "transcendence" was of aesthetic, not theological, nature, so that art and not the Bible would function as a guarantor of truth. An anti-Christian reading of the metaphor of 'life as a dream' would lead to nihilism, which, as Simerka notes, is of course linked to a later phase of epistemological uncertainty. Nevertheless, Simerka argues, this observation of the death portrayed on stage in the English revenge drama could serve as a basis for understanding the metadramatic stagings of martyrdom presented by Lope (and Rotrou) as a "mediat[ion] of early modern forms of skepticism." Even if the authors (Lope and Rotrou) believed in the power of theater to deal with miracles and redemption and to create epistemological certainty about life, death, and the hereafter, the conclusion could still be regarded as illusory, even though the beliefs of the recipients no longer coincided with those of the authors and the protagonist, especially since unorthodox philosophical and theological teachings were known among the contemporary audience. Cf. pp. 70 f. (also following Hall, "Illusion et vérité dans deux pièces de Lope de Vega” [cf. note 494], p. 43 [referring to 'modern readers']).

620 P. 69. 
[...] [T] he staging of martyrdom evokes the death of the first and most revered Christian martyr, but also distances the spectator and ruptures identity with Genesius and Christ through the reflexive nature of the actor's conversion and death. In the context of this narrative of the ultimate gesture of faith, the meta-artistry in these two plays can be seen as a radical affirmation of the skeptical mode of thought, questioning not only human ability to perceive the difference between theatrical illusion and material reality, but also human capacity to attain meaningful knowledge of the relationship between material reality and divine revelation. ${ }^{621}$

Considering the analysis of Lope's drama that has been carried out here so far, this interpretation appears problematic with regard to the 'message' of the play. Simerka for example makes no reference to the important theological implications of the drama that are not only present in Ginés' speeches as a converted Christian and his martyrdom, but also concern the complex overall composition (the multilayered preparation for Ginés' becoming a Christian, the change of the false worldly love to the true love of God; the transition from a played [fingido] to the 'lived right role' [verdadero]; etc.). ${ }^{622}$

621 P. 71 (my italics). In this context, Simerka's interpretation of Ginés' 'rehearsal scene' in the third act (vv. 2414-2588) should be mentioned, in which, as Ginés asks for baptism, the 'miraculous opening of the heavens' happens, though only visible to the audience, and he hears a voice that promises him salvation, but whose origin he does not know to clearly identify (Fabio or indeed a call from heaven): "For the 'real' audience, the Christian and the stage miracles are conflated, for even the devout spectator who believes that God did indeed intervene in the actor's life is still aware that the apparently miraculous revelation of the picture is actually a result of stage machinery. This may very well be one of the most subversive moments of Lope's play, for it demonstrates the ease with which miracles may be contrived. Although the play does appear to support belief in Christian ideology, through the representation of Genesius' heroic acceptance of martyrdom and his firm belief in a glorious afterlife, it simultaneously draws attention to the possibilities for deception. Not only everyday life, but also extraordinary occurences are shown to be opaque rather than obvious, and subject to interpretation" (pp. 62 f.; my italics; cf. as well p. 65 regarding the corresponding scene in Rotrou).

622 Cf. also the - polemically expressed - reference in Florence D'Artois in view of an ahistorical application of 'metatheater' concepts, given in his interpretation of the final scene: “[...] [P]ara Ginés, e[l] fin no es sino el principio de otra vida. Tiene futuro en el teatro divino. Dice: 'Mañana temprano espero / para la segunda parte' (III, vv. 3120-3121). Hasta el último momento la fábula se anula y ostenta su anulación, pero para mejor evidenciar, otra vez, la estructura oculta de la fábula ideada por Dios. Al morir, Ginés no cae en un precipicio, sino que salta a la escena de Dios. Por lo tanto, desde esta perspectiva, su fábula no acaba. La estructura de Lo fingido verdadero sería incomprensible sin el horizonte de esta demostración. Más que laboratorio de compositio dramática, Lo fingido verdadero es un ejemplo de perfecta adecuación de una forma estética a una postura metafísica. Por más decepcionante que sea esta conclusión para un estudioso del siglo XXI, amante del formalismo y de la metateatralidad, ocultar las evidentes conexiones del procedimiento del teatro en el teatro con el topos del theatrum mundi, sería traicionar nuestro objeto de estudio" (D’Artois, "El teatro en el teatro en Lo fingido verdadero" [cf. 494], p. 188). 
To further support the interpretation represented here, I shall now refer to the historical context (which was common knowledge at that period) in which the play is situated.

Ginés confesses himself a Christian before Emperor Diocleciano, whose (chaotic) rise to power takes up a considerable part of the comedia's plot as a whole, and his (Ginés') death as a martyr closes the play. This is significant in terms of the interpretation of the play and classification of the figure of Genesius. Mexía's Historia imperial y cesárea, Lope’s source for the Genesius material, states: “[...] [D]etermino Diocleciano [...] de perseguir la yglesia, y fue esta la decima persecucio[n] general, despues de la de Nero[n], y la mas cruel de todas, y q[ue] mas tie[m]po duro [...]."623 Diocletian was not only considered one of the cruelest persecutors of Christians, but also - and this is decisive - in principle the last major Roman emperor to do so. ${ }^{624}$ His successor

Cf., furthermore, Canning's examination of Lope's drama as "Metaplay," and her concluding comment: "Ultimately, Lope's play expresses a sense of disillusion with life. While the relationship between amor divino and amor humano is not the principal focus of Lo fingido verdadero, the play does discredit negative attitudes and forms of behaviour associated with human love, while divine love triggers Ginés' martyrdom and assumption of his true role." (Canning, "Lo fingido verdadero as Metaplay" [cf. note 494], here p. 127).

623 Mexía, Historia imperial y cesárea (cf. note 500), p. 130r b. On pp. 130r a-130v b there is a more detailed description of persecution and cruelties that ends with the words: "Finalmente se hizieron crueldades nunca vistas, y fue grandissima la multitud los muertos, enel tiempo que duro esta persecucion” (p. 130v a-b).

624 In his introduction to Lactantius' book On the Deaths of the Persecutors, Alfons Städele sums up: 'From when and for what reasons there were persecutions of Christians, i.e. a state action that was predominantly or exclusively directed against Christians, is a matter of debate. In the Christian tradition, Nero was the first, Diocletian the last, great persecutor of Christians' ("Ab wann und aus welchen Gründen es Christenverfolgungen gegeben hat, ein staatliches Vorgehen also, das sich überwiegend oder ausschließlich gegen Christen richtete, ist umstritten. In der christlichen Tradition galt jedenfalls Nero als der erste, Diokletian als der letzte große Christenverfolger"). Given a 'minimum configuration of persecutor emperors' (“'Mindestausstattung' an Verfolgerkaisern”) - Nero, Domitian, Valerian, and Diocletian - there were usually ten or six major persecutions mentioned. (Alfons Städele, "Einleitung," in: Lactantius, De mortibus persecutorum [cf. note 516], pp. 7-88, here p. 19 with note 23). In Lactantius, however, it is Galerius Maximianus, not Diocletian, who is represented as the actual author of the bloody persecutions (cf. De mort. pers. 10,5 f.; 11,8; 14,1 f. [pp. 116 f., pp. 120 f., pp. 122 ff.; Lactantius, Of the Manner in Which the Persecutors Died (cf. note 516), pp. 304 ff.]). The beginning of the official persecution of Christians marks an edict issued by Emperor Diocletian and his co-rulers (the second Augustus Maximian and the two Caesars Constantius Chlorus and Galerius) on 23 February 303 for the entire Empire. However, its implementation and development were different in the individual parts of the empire. On the persecution of Christians under Diocletian, cf. (the older studies:) Jacques Moreau, Die Christenverfolgung im Römischen Reich, 2nd ed., Berlin/New York 1971 (1st ed. 1961; La persécution du Christianisme 
Constantine the Great (r. 306-337, sole ruler from 324) made Christianity the official religion of the empire.

Between the abdication of Diocletian and Maximian in 305 and until Constantine became sole emperor in 324, the Roman Empire was ruled by an oft-shifting tetrarchy and experienced a period of tumultuous change. During the course of this period Christianity came to be increasingly accepted and tolerated. ${ }^{625}$

dans l'Empire Romain, Paris 1956), pp. 98-119 and Joseph Vogt, Constantin der Große und sein Jahrhundert, 2nd ed., Munich 1960 (1st ed. 1949), pp. 121-133; as well as Demandt, Die Spätantike (cf. note 500), pp. 69 ff.; Kuhoff, Diokletian und die Epoche der Tetrarchie (cf. note 500), pp. 246-297. (For the Diocletian Tetrarchy, see above note 519).

625 After the abdication of the two Augusti Diocletian and Maximian in 305, Constantine's father Constantius Chlorus in the West and Galerius Maximianus in the East, became emperors, and Flavius Valerius Severus and Maximinus Daia were appointed Caesares. In June 306, Constantine had himself proclaimed Augustus by the troops in Britain, after his father had died during a campaign. Galerius, as the highest-ranking emperor, recognized Constantine as Caesar but appointed Severus Augustus of the western part of the empire. With the claims to power of Maxentius, son of the resigned Maximian, - he also had himself proclaimed emperor in Rome in 306 - and of Maximian, who in turn had declared himself Augustus, the balance of power and the corresponding disputes became even more complicated. An imperial conference led by Diocletian convened in 308 to consolidate the system. It was decided to remove Maxentius and Maximian, downgrade Constantine back to Caesar in the West, and appoint Licinius as the new Augustus to replace the dead Severus. However, this led to no pacification of the rivals - Maxentius could assert his power in the center of the empire, but Constantine called himself Augustus on his own authority - and could not stop the continued dissolution of the Tetrarchy. The senior emperor Galerius died in 311. It is noteworthy that Galerius, who, together with his junior emperor Maximinus Daia, had most consistently executed the Diocletianic persecution decrees, issued an edict in the name of all four reigning emperors shortly before his death to tolerate the Christian religion, which enabled it to exist on equal footing with the other religions worshipped in the Roman Empire. Both Maxentius and Constantine - like his father before him - pursued a policy of tolerance towards Christians. This very rough summary of the events and situation between the years 305 and 312 is based on the accounts in Demandt, Die Spätantike (cf. note 500), pp. 75-103, here pp. 75-81; Andresen/Erbse et al. [eds.], Lexikon der Alten Welt (cf. note 500), cols. 1586 ff. (entry "Konstantin I d.Gr.”), here cols. 1586 f.; Vogt, Constantin der Große und sein Jahrhundert (cf. note 624), pp. 137-153; cf. as well the résumé (with reference to Vogt and András Alföldi, The Conversion of Constantine and Pagan Rome, Oxford 1948) in Joachim Küpper, Discursive Renovatio in Lope de Vega and Calderón: Studies on Spanish Baroque Drama, Berlin/Boston 2017, pp. 163-168, here pp. 164 ff. Regarding the subsequent set of events (extensively discussed in research), Constantine's conflict with Maxentius, the decisive battle at the Milvian Bridge, and the aspect of the traditional vision and conversion of the emperor, and the beginning of the dominance of Christianity attributed to it, see Vogt, Constantin der Große und sein Jahrhundert, pp. 154-166; Demandt, Die Spätantike, pp. 82 ff.; cf. as well Weber, Kaiser, Träume und Visionen (cf. note 516), pp. 274-292. 
In the Christian version of events, however, that informed the 'conception of history' and what was known about the period in Lope's time, the Roman Empire's rejection of paganism and acceptance of Christianity as the one true religion was a sudden and miraculous event, exclusively linked with the first Christian emperor Constantine. The basis for this understanding was the account by Lactantius (c. 250-320 CE) in his De mortibus persecutorum [On the Deaths of the Persecutors] ${ }^{626}$ and, in particular, the influential Vita Constantini [Life of Constantine] by Eusebius of Caesarea (c. 264-339/340 CE). According to Eusebius' account, the story about Constantine's 'miraculous' conversion to Christianity is that on the eve of the decisive battle between Constantine and Maxentius at Milvian Bridge in 312, Constantine sought divine assistance to win the day. Taking into account the failures of his predecessors who had worshipped pagan gods and the success of his father, who had already turned to the Christian faith, he decides to call on the God of the Christians (not yet 'familiar' to him) for help. (This is historically inaccurate, as by all accounts Constantine's father Constantius Chlorus was not a Christian. ${ }^{627}$ ) Constantine began to pray and suddenly "a most remarkable divine sign" appears to him. ${ }^{628}$ Before his eyes and those of the whole army a cross of light appears in the sky over the sun with the words "By this [sign] conquer!" (toúto níka). ${ }^{629}$

626 Cf. Lactantius De mort. pers. 44,1-10 (Lactantius, De mortibus persecutorum [cf. note 516], pp. 200-204; Lactantius, On the Manners in Which the Persecutors Died [cf. note 516), p. 318); see above note 516 .

627 Eusebius of Caesarea, De vita Constantini I, 27 (Eusebius of Caesarea, De vita Constantini/ Über das Leben Konstantins [Greek-German], introd. Bruno Bleckmann, trans. and ed. Horst Schneider, Turnhout 2007; Eusebius of Caesarea, Life of Constantine, ed. and trans. Averil Cameron and Stuart G. Hall, Oxford 1999, pp. 79 f.; in the following, page numbers refer to the English translation). Eusebius previously contrasts Constantine's father Constantius Chlorus with the other Tetrarchs, who are described as tyrannical persecutors of Christians (I, 13-18 [pp. 74-77]), where it reads about him: "When four men shared power in the Roman Empire, this man was the only one who adopted an independent policy and was on friendly terms with the God over all" (I, 13,1 [p. 74]) or as well: "When he had for a long time given proofs of his merit as an emperor, recognizing only the God over all and condemning the polytheism of the godless, and had fortified his house all around with the prayers of holy men, he finally finished the course of his life serenely and undisturbed [...]” (I, 17,2 [p. 76]). Cf. also the following statement, which is made after having told about Constantius' death and Constantine's 'adoption' of his father's imperial position: "In such a way then did God, the President of the whole world, of his own will select Constantine, sprung from such a father, as universal ruler and governor, that no man could claim the precedence which he alone possessed, since the rest owed the rank they held to election by others” (I, 24 [pp. 78 f.]).

628 I, 28,1 (pp. 80 f.).

629 "About the time of the midday sun, when day was just turning, he said he saw with his own eyes, up in the sky and resting over the sun, a cross-shaped trophy formed from light, 
Constantine does not understand and "wonder[s] to himself what the manifestation might mean [...]." ${ }^{630}$ That night, Christ appears to him in a dream and instructs him to use the sign of the cross in battle as a measure of defense against his enemies. ${ }^{631}$ The next day he orders a magnificent banner to be made, bearing Christ's monogram. ${ }^{632}$ Furthermore, he asks Christian priests to explain to him the meaning of the sign of the cross and is introduced by them to the teachings of Christianity. ${ }^{633}$ He then declares that he wants to study the Holy Scriptures himself, makes the priests his advisors, and determines " [. . .] to honour the God who had appeared to him with all due rites." ${ }^{634}$ Constantine then fights in the name of $\operatorname{God}^{635}$ against the tyrannical 'pagan' Maxentius,


cle seized both him and the whole company of soldiers which [...] witnessed the miracle" (I, 28,2 [p. 81]). According to Eusebius, he had heard the account of the vision and events from Constantine himself ("If someone else had reported it, it would perhaps not be easy to accept; but since the victorious Emperor himself told the story to the present writer [. . . ] and confirmed it with oaths, who could hesitate to believe the account[?] [. . .]" [I, 28,1 (p. 81)]).

630 I, 29 (p. 81).

631 I, 29 ("[A]s he slept, the Christ of God appeared to him with the sign which had appeared in the sky, and urged him to make himself a copy of the sign which had appeared in the sky, and to use this as protection against the attacks of the enemy" [p. 81]). Note the striking shift of emphasis and the elaboration towards a 'miracle' in Eusebius in comparison to the earlier text. In Lactantius, before Constantine's battle against Maxentius, it reads only: "Commonitus est in quiete Constantinus, ut caeleste signum die notaret in scutis atque ita proelium commiteret. Fecit, ut issus est, et transversa X littera, summo capito circumflexo Christum in scutis notat” (De mort. pers. 44,5 [Lactantius, De mortibus persecutorum (cf. note 516), pp. 200/202])/ 'Constantine was directed in a dream to cause the heavenly sign to be delineated on the shields of his soldiers, and so to proceed to battle. He did as he had been commanded, and he marked on their shields the letter $\mathrm{X}$, with a perpendicular line drawn trough it and turned round thus at the top, being the cipher of Christ' (Lactantius, On The Manner in Which the Persecutors Died [cf. note 516], p. 318; italics in the original).

632 See Eusebius of Caesarea, De vita Constantini I, 30 f. (Eusebius of Caesarea, Life of Constantine [cf. note 627], pp. 81 f.), the detailed description of the labarum in I, 31,1-2 (pp. 81 f.), then the foresight: "This saving sign was always used by the Emperor for protection against every opposing and hostile force, and he commanded replicas of it to lead all his armies" (I, 31,3 [p. 82]).

633 See I, 32,1-2 (p. 82).

634 I, 32,3 (p. 82).

635 Cf. I, 37,1 ("So taking as his patron God who is over all, and invoking his Christ as saviour and succour, and having set the victorious trophy, the truly salutary sign, at the head of his escorting soldiers and guards, he led them in full force [...]" [p. 84]). Note that in Eusebius, Constantine's vision is not immediately before the battle at the Milvian Bridge, but is set before the campaign against Maxentius and his conquest of parts of Italy (see I, 37,2 [p. 84]). 
whose infamies and cruelties are described in extenso. ${ }^{636}$ He wins a decisive victory "by God's will" 637 when, attempting to cross the Tiber on a bridge that he had built across the river, a folding mechanism malfunctions and Maxentius and his troops are plunged into the water and drown. This is given further significance by comparing these events with the Exodus story of the drowning of Pharaoh and his army in the Red Sea, an image that equates Constantine with the biblical Moses and his troops to the Israelites, the chosen people of God. ${ }^{638}$ Constantine, joyfully received in Rome after the victory, immediately offers "[...] a prayer of thanksgiving [...]" to the Christian God, "[...] the Giver of his victory." 639 He celebrates this victory of the cross with inscriptions and monuments and preaches his new faith ("The Godbeloved Emperor, proudly confessing in this way the victory-bringing cross, was entirely open in making the Son of God known to the Romans"), ${ }^{640}$ accepts church dignitaries into his inner circle, supports Christian communities, and has churches built. ${ }^{641}$

636 Cf. I, 33-36 (pp. 82 f.).

637 I, 38,4 (p. 84).

638 I, 38 (pp. 84 f.); the comparison is in I, 38,2 ("Accordingly, just as once in the time of Moses and the devout Hebrew tribe 'Pharaoh's chariots and his force he cast into the sea, and picked rider-captains he overwhelmed in the Red Sea' [Exodus 15: 4], in the very same way Maxentius and the armed men and guards about him 'sank to the bottom like a stone' [Exodus 15: 5], when, fleeing before the force which came from God with Constantine, he went to cross the river lying in his path” [p. 84]) and I, 38,4 f. (pp. 84 f.).

639 I, 39 (p. 85), quote in I, 39,3 (p. 85).

640 I, 40-41,1 (pp. 85 f.), quote in I, 41,1 (p. 86).

641 See I, 42 (p. 86). Küpper stresses that the narrative in Eusebius is modeled according to the schema of the conversion of Saul to the Christian Paul: "The emperor is taken to be the analog of Saul/Paul, the world-historical turning point to be the analog of the salvation-historical turning point" (Discursive Renovatio [cf. note 625], p. 175; on the account in Eusebius, cf. as a whole pp. 171-176, on the Pauline pattern, cf. pp. 173-176; [the observations are part of the analysis of Calderón's auto sacramental La lepra de Constantino: chap. 3.3.3 "The Incorporation of PostHistory: La lepra de Constantino,” pp. 161-219]). Thus, the Eusebian version, unlike that of Lactantius, "[.. .] not only [. . . s shapes all events in accordance with a general conception of history as guided by God, [...] but that its author completely redesigned them according to a preexistent narrative schema" (p. 170; on the modeling of the story in Lactantius, cf. altogether pp. 168-170). According to the structural pattern given there, it forms the basis for the Christian tradition of depicting the change of epoch (see: "The subsequent Christian tradition [...] may be seen as the consistent organization of a material that, in its basic outlines, is already modeled according to its one 'true' structure in Eusebius" [p. 176]). However, what has been said in this regard must also be modified in view of Constantine's exclusive attachment to the epochal turning point in such a way that this applies to the comparison with his imperial opponents. With the influential modeling of events in the early medieval Sylvester-legend, as Küpper points out, the significance of his role changes: "Constantine is no longer the main protagonist of the 
Soon after his victory over Maxentius, Constantine, now ruler over the entire western part of the empire, favors the Christian cult, for instance by donating the Lateran to the Bishop of Rome. ${ }^{642}$ In February 313, the two co-emperors Constantine and Licinius (ruler of the eastern part of the empire) published the so-called Edict of Milan, which guaranteed freedom of religion for Christianity as well as pagan cults but enhanced the status of Christianity and favored the Christian communities (e.g. by the restitution of goods and properties). Licinius continued to rule in the east until defeated by Constantine in 324. The conflict between them came to have a religious overtone, as Constantine was proChristian and Licinius was anti-Christian. With Constantine's victory, Christianity became the dominant religion of the empire. Constantine built numerous churches, privileged the clergy and Christian communities and transfered state tasks and rights to the Great Church. He also worked to strengthen the unity of the Christian cult. As early as 314, Constantine was active in this regard, intervening in what is known as the Donatist Controversy that year. In 325 he convened the Council of Nicaea to settle a dispute over the teachings of Arius and took an active part in it himself. He moved his seat of government to Byzantion and renamed the new capital after himself. The city's layout and the inauguration of Constantinople in 330 clearly emphasized that this 'New Rome' was a Christian one. Constantine died in 337, after having been baptized, and was buried in the mausoleum he had prepared in Constantinople near the Church of the Apostles,

world-historical transition, but a subsidiary figure in the vita of the Roman bishop Sylvester, during whose pontificate this change is said to have taken place" (p. 178). In addittion, cf.: "The basic schema is retained: there is, once again, the explicit modeling of historical development as orchestrated by God himself, including an abrupt change, presented as a conversion caused by a miracle. Yet the content that fills in the schema is altogether altered, specifically by an almost complete displacement of the actual historical substrate in favor of a now utterly miraculous [...] storyline" (p. 176; for the legend of Sylvester, cf. pp. 176-184; for the field of questions regarding the so-called 'Donation of Constantine' - the legend of Sylvester is an integral part of the forged document -, cf. pp. 184-197).

642 The following summary is based on the accounts in Demandt, Die Spätantike (cf. note 500), pp. 85-103; Andresen/Erbse et al. (eds.), Lexikon der Alten Welt (cf. note 500), cols. 1586 ff. (entry "Konstantin I d. Gr."), here cols. 1587 f.; Vogt, Constantin der Große und sein Jahrhundert (cf. note 624), pp. 166-256 (on the 'Edict of Milan,' cf. pp. 168-171; for Constantine's politics regarding Christians, cf. i.a. esp. pp. 166 ff., pp. 174-184 [for the politics of Licinius, cf. pp. 184 ff.], pp. 194-199,pp. 202 f.; on Constantinople, cf. pp. 214-218, pp. 252 f.; on his death and burial, cf. pp. 253 ff.); Küpper, Discursive Renovatio (cf. note 625), pp. 164 ff.; Klaus Martin Girardet, Der Kaiser und sein Gott: Das Christentum im Denken und in der Religionspolitik Konstantins des Großen, Berlin/New York 2010, pp. 124-163; Hartwin Brandt, Konstantin der Große: Der erste christliche Kaiser, Munich 2006, pp. 68-89, pp. 108-145, pp. 156-167. 
symbolically surrounded by the tombs of the twelve apostles, a 'thirteenth apostle' or even as Christlike. Under the reign of Theodosius (r. 379-394), Christianity (following the Nicene creed) was declared to be the exclusive state religion, and all other forms of worship (including divergent Christianities) were banned.

Constantine's reign marks a religious-historical caesura of historical significance. However, questions about his motivations, the timing of his conversion, and about the status of his Christian convictions remain a topic discussed in research to this day. ${ }^{643}$ The Christian tradition, as shown above, models this upheaval as an abrupt event, brought about by Constantine's miraculous conversion at the hand of God who led him to victory over Maxentius and the predetermined triumph of 'true faith' over paganism. Viewed against this background, with its themes of salvation and historical veracity, Lope de Vega's Ginés obtains an added dimension. In the vita of Ginés this miraculous shift - from paganism to Christianity - is in a sense prefigured: the immoral empire, addicted to lust and debauchery, 'suddenly' transforms into the refuge and guardian of true religion. ${ }^{644}$ It is interesting to note a certain structural similarity, hinted at in

643 Cf. Bruno Bleckmann's evaluation: "So unbestritten es also sein muß, daß mit der Regierung Konstantins ein völlig neues und folgenreiches Kapitel im Verhältnis zwischen Kirche und Staatsmacht beginnt, so unklar ist alles übrige, etwa die Frage, welche Motive Konstantin verfolgte und ob die Beziehung der Kirche zur Staatsmacht sich nicht ohnehin als Notwendigkeit abzeichnete, die auch von den Kaiserkollegen Konstantins wie Galerius oder Licinius erkannt wurde. In der Diskussion um die Konstantinische Wende kann eine alle überzeugende Lösung niemals gefunden werden" [While it cannot be denied that Constantine's reign marks the beginning of a completely new and momentous chapter in the relationship between church and state power, everything else seems unclear, such as the question of what were Constantine's motives and whether the relationship of the church to state power was not in any case a necessity, which had also been identified as such by Constantine's emperor peers, e.g. Galerius or Licinius] (Bruno Bleckmann, "Einleitung," in: Eusebius of Caesarea, De vita Constantini [cf. note 627], pp. 7-106, here pp. 7 f., with reference to the study by Klaus Martin Girardet, Die Konstantinische Wende: Voraussetzungen und geistige Grundlagen der Religionspolitik Konstantins des Großen, Darmstadt 2006 [cf. there pp. 41-56, esp. pp. 48-52]). Cf. also Städele’s summarizing remark: “[...] daß Konstantin sich bereits 312 zum Christentum bekehrt hatte, ist zumindest zweifelhaft. Heute nimmt, wer nicht mit Jacob Burckhardt und Henri Grégoire in ihm sowieso nur den von Glaubensfragen innerlich unberührten, reinen Machtpolitiker sieht, eher einen allmählich fortschreitenden Prozeß an" [it is at least doubtful that Constantine had already converted to Christianity in 312. Today, anyone who does not see in him, following Jacob Burckhardt and Henri Grégoire, only the pure power politician who is inwardly untouched by questions of faith, rather assumes a gradually progressing process] (Städele, "Einleitung” [cf. note 624], pp. 7 f. with note 3 [p. 8], there references to publications of the position that the Constantinian 'shift' had taken place in 312 and to 'mediating' studies).

644 Although Ginés' transformation from an acting to a real Christian has already been discussed, it is the abruptness of this 'inner transformation' that is being pointed out here. 
Eusebius' writing, which is more broadly developed in Lo fingido verdadero. When Constantine prays to the Christian God before the battle he does not do so as a Christian, but rather prays, so to speak, 'on the off chance,' out of sheer expediency, in the hopes of receiving from this God the necessary support to be victorious. ${ }^{645}$ At this point, he is not yet able to understand the miracle ${ }^{646}$ that takes place during his prayers - the sign of the cross appearing in the sky with the words 'By this (sign) conquer!' The next day, having been visited by Christ in a dream, he follows his command to carry a copy of the sign into battle, ${ }^{647}$ he instantly does so and fights under the 'cross-shaped trophy, ${ }^{648}$ without knowing its meaning: "At the time in question, stunned by the amazing vision, and determined to worship no other god than the one who had appeared, he summoned those expert in his words, and enquired who this god was, and what was the explanation of the vision which had appeared of the sign."649 Thus, Constantine speaks and acts according to the role assigned to him by God, namely, as

Furthermore, it is worth drawing attention once again to the explicit opposition of 'true faith,' 'right religion' and 'false' paganism, which is also expressed in Ginés' closing speech: 'yo fui figura gentil / adorando dioses tales; recibióme Dios; ya soy / cristiano representante;' (vv. 3108-3111).

645 "Knowing well that he would need more powerful aid than an army can supply [...], he sought a god to aid him" (Eusebius of Caesarea, De vita Constantini [cf. note 627], I, 27,1; Life of Constantine [cf. note 627], pp. 79 f.; for the considerations already mentioned in the above description, which lead to his decision, see in total I, 27 [pp. 79 f.]).

646 "This God [the god of his father, i.e. the Christian god] he began to invoke in prayer, beseeching and imploring him to show him who he was, and to stretch out his right hand to assist him in his plans. As he made these prayers and earnest supplications there appeared to the Emperor a most remarkable divine sign” (I, 28,1 [pp. 80 f.]; for the description of the miracle, cf. I, 28,2 [p. 81] and the explanations above).

647 Cf. I, 29 (p. 81).

648 Cf. I, 30 f. (pp. 81 f.).

649 I, 32,1 (p. 82), the corresponding 'introduction' by the Christian priests then in I, 32,2 (“They said that the god was the Onlybegotten Son of the one and only God, and that the sign which appeared was a token of immortality, and was an abiding trophy of the victory over death, which he had once won when he was present on earth. They began to teach him the reasons for his coming, explaining to him in detail the story of his self-accommodation to human conditions" [p. 82]) Constantine, "[...] while he marvelled at the divine manifestation which had been granted to his eyes" (I, 32,3 [p. 82]), however, finally, considering "[. . .] the heavenly vision with the meaning of what was being said [...]" (ibid.), is "[...] convinced that it was as God's own teaching that the knowledge of these things had come to him" (ibid.). Now he turns 'consciously' towards Christianity: He considers his own study of the Book of Christians as important, appoints Christian priests as his advisors and decides on the ritual veneration of the Christian God (ibid.). He goes to war in the name of this god: "Thereafter, fortified by good hopes in him [the new God], he finally set about extinguishing the menacing flames of tyranny" (ibid.). 
a Christian or as a victorious fighter in the name of God and the first Christian emperor, even before he is aware of accepting this for himself.

Ginés first plays the role of a Christian in the narrower, profane sense, that is, he mimes the figure of the Christian martyr on the stage. When, during rehearsal of this role, he addresses the request for baptism to God, which turns out to be unexpected for him as well, he hears a voice that promises him the 'salvation of his soul.' He is not able, however, to undestand the meaning and ontological status of this perceived voice or his internal reaction to it. In the course of the subsequent performance, the merging of 'stage role' and 'serious, conscious speech and action,' which is now indistinguishable for spectators and actors, is condensed. The 'play within the play' ends with Ginés' death sentence, which Diocleciano imposes on him, after he is certain that Ginés speaks these words 'in earnest.' The concept of a Goddetermined world and role assigned to human beings in God's plan is explicitly articulated in Lope's drama. Ginés integrates the Christian 'world as a stage' metaphor into his reflection on his conversion to Christianity a miracle achieved through God's grace - and his impending martyrdom. The fact that he is aware of his 'new role' while at the same time recognizing that he has unconsciously already 'acted correctly' is expressed in the first quartet of his last sonnet monologue: 'Mi Dios, cuando por burlas fui cristiano / y me llamastes a tan altas veras, / representaba burlas verdaderas / en el teatro de mi intento vano' (vv. 2966-2969). His readiness to embody the role intended for him despite the consequences is made clear by the final image. This shows an impaled Ginés, who, in his final lines declares the fictitiousness of all earthly things and the 'false life' he had led up to his conversion as opposed to the 'true faith' and the reward awaiting him in the hereafter. It should be noted that his antagonist Diocleciano (unconsciously) fits himself into the plan of the 'divine director' by, when he pronounces the death sentence on Ginés, putting that what will follow after it into the framework of a comedia and giving himself the position of an actor in it: '[. . . quiero hacer mi dicho / y morirás en comedia / pues en comedia has vivido. / Siéntome como tribuno: / traedle aquí. [...] / [. . ] / [ . . t te sentencio a muerte[:] / [...] / y acabaré mi papel / con que Léntulo y Sulpicio / prendan y examinen luego / a cuantos vienen contigo' (vv. 2881-2894; my italics). At the level of the play, this again blurs the line between reality and illusion - Diocleciano's verdict ends the internal fiction - or rather: earthly reality is deprived of its epistemically superior status and degraded to 'world theater.'

Several references have already been made to the figural-typological dimension of Lope's drama. In Erich Auerbach's formative essay on the concept 
of figural interpretation ${ }^{650}$ he writes: "Originally figura, from the same stem as fingere, figulus, factor, and effigies, meant 'plastic form.' Its earliest occurrence is in Terence [...]." 651 Both the reference to the etymological relationship between fingere, the source of the Spanish fingir with the participle fingido, as well as the mention of the first documentation of the term in Terence, an ancient writer of comedy, i.e. in a theater text, already establishes striking points of reference. Auerbach goes on to trace the development of the term figura, showing that it relates, among other things, to "movement and transformation,”652 “[the meanings] 'model,' 'copy,' 'figment,' 'dream image,",653 “[t]he sense of 'appearance,",654 “[the] play on model and copy,"655 "the shades of meaning between model and copy, [...] [the] changing form and the deceptive likenesses that walk in dreams," ${ }^{656}$ and finally "[...] the creative, formative principle, change amid the enduring essence, the shades of meaning between copy and archetype." ${ }^{657}$ The latter elements already show Christian influences on the term, and relate it to a second pool of referents, which the 'figure' points (forward) to, that of truth, veritas, or fulfillment (in Lope: 'lo verdadero'). At the end of his study, Auerbach expresses a conception of the Christian figural concept of history:

[...] the figural interpretation of reality [...]: the idea that earthly life is thoroughly real, with the reality of the flesh into which the Logos entered, but that with all its reality it is only umbra and figura of the authentic, future, ultimate truth, the real reality that will unveil and preserve the figura. In this way the individual earthly event is not regarded as a definitive self-sufficient reality, nor as a link in a chain of development in which single events or combinations of events perpetually give rise to new events, but viewed primarily in immediate vertical connection with a divine order which encompasses it, which on some future day will itself be concrete reality; so that the earthly event is a prophecy or figura of a part of a wholly divine reality that will be enacted in the future. But this reality is not only future; it is always present in the eye of God and in the other world, which is

650 Auerbach, "Figura” (cf. note 240); Auerbach, "Figura," trans. (cf. note 240).

651 Auerbach, "Figura," trans., p. 11; "Figura, vom gleichen Stamme wie fingere, figulus, fictor und effigies, heißt nach seiner Herkunft 'plastisches Gebilde' und findet sich zuerst bei Terenz [...]" (Auerbach, "Figura," p. 55).

652 P. 16; "Bewegung und Verwandlung” (p. 57).

653 P. 17; “[die Bedeutungen] Urbild, Abbild, Scheinbild, Traumbild” (p. 58).

654 P. 18; "das sinnlich Erscheinende" (p. 59).

655 P. 16; "Spiel zwischen Urbild und Abbild” (p. 58).

656 P. 21; "d[as] Spiel zwischen Urbild und Abbild, d[er] Gestaltwandel, d[as] täuschend nachahmende Traumbild” (p. 61).

657 P. 49; “[... .] das Schöpferisch-Bildende, de[r] Wandel im bleibenden Wesen, das Spiel zwischen Abbild und Urbild [. . .]" (p. 74). 
to say that in transcendence the revealed and true reality is present at all times, or timelessly. ${ }^{658}$

The events of this world do not stand for themselves, but take part in a comprehensive network of meaning, also within the framework of salvation history, whose vertical principle of order is embodied by the omniscient God.

The concept of figural interpretation is inherent in the title Lope chose for this comedia. The reciprocal dynamics of lo fingido and lo verdadero, made distinct there and then elaborated on in the play, corresponds precisely to the conception of the two poles figura and veritas (or fulfillment), because each of the terms contains an element or presence of the other as well, 'figura/umbra' refers to its fulfillment, in 'veritas' the figure is present. A typical prefiguration (or typos) would be Adam as a prophecy of Christ. ${ }^{659}$

658 P. 72; “[. . .] die Figuraldeutung der Wirklichkeit [. . .]: daß das irdische Leben zwar durchaus wirklich sei, von der Wirklichkeit jenes Fleisches, in das der Logos einging, aber in all seiner Wirklichkeit doch nur umbra und figura des Eigentlichen, Zukünftigen, Endgültigen und Wahren, welches die Figur enthüllend und bewahrend, die wahre Wirklichkeit enthalten werde. Auf diese Art wird jedes irdische Geschehen nicht als eine endgültige, sich selbst genügende Wirklichkeit angesehen, auch nicht als Glied in einer Entwicklungskette, wo aus einem Ereignis oder aus einem Zusammenwirken mehrerer immer wieder neue Ereignisse entspringen, sondern es wird zunächst im unmittelbaren vertikalen Zusammenhang mit einer göttlichen Ordnung betrachtet, in der es enthalten ist und die selbst eines künftigen Tages geschehene Wirklichkeit sein wird; und somit ist das irdische Ereignis Realprophetie oder figura eines Teiles zukünftig geschehender, unmittelbar vollendet göttlicher Wirklichkeit. Diese aber ist nicht nur zukünftig, sondern in Gottes Auge und im Jenseits jederzeit gegenwärtig, so daß dort jederzeit, oder auch zeitlos, die enthüllte und wahre Wirklichkeit vorhanden ist” (p. 89).

659 "Figural prophecy implies the interpretation of one worldly event through another; the first signifies the second, the second fulfills the first. Both remain historical events; yet both, looked at in this way, have something provisional and incomplete about them; they point to one another and both point to something in the future, something still to come, which will be the actual, real, and definitive event. This is true not only of Old Testament prefiguration, which points forward to the incarnation and the proclamation of the gospel, but also of these latter events, for they too are not the ultimate fulfillment, but themselves a promise of the end of time and the true kingdom of God. Thus history, with all its concrete force, remains forever a figure, cloaked and needful of interpretation" (p. 58; "Die Figuralprophetie enthält die Deutung eines innerweltlichen Vorgangs durch einen anderen; der erste bedeutet den zweiten, der zweite erfüllt den ersten. Zwar bleiben beide innergeschichtlich geschehene Ereignisse; aber doch enthalten beide, die in dieser Betrachtungsweise, etwas Vorläufiges und Unvollständiges; sie weisen aufeinander, und beide weisen auf etwas Zukünftiges, welches erst noch bevorsteht und welches erst das Eigentliche, voll und wirklich endgültige Geschehende sein wird. Dies gilt nicht nur von der alttestamentlichen Praefiguration, die auf die Inkarnation und die Verkündung des Evangelium hindeutet, sondern auch von diesen, denn auch sie sind ja noch nicht endgültige Erfüllung, vielmehr auch ihrerseits Verheißung 
In view of the historical understanding on which the play is based, it is possible to read the figure of Ginés as a prefiguration of Constantine. With regard to theater, on the one hand, the (pagan) tragedy is to be understood as a prefiguration of the Christian comedy, the story with a good ending. Furthermore, against this background, in the context of the theatrum mundi metaphor, the theater and the 'theater within the theater,' the 'play within the play,' are given more farreaching significance.

Despite all the differences in language, plot, and rhetoric, the parallels between Calderón's and Lope de Vega's dramatization of the issue of skepticism are striking. This can be understood as a clear indication of how much the two dramas are anchored in the ideological-cultural context in which they arose. According to the basic tenor of the skeptical tradition, reality and deception (dream, fiction) are ultimately not entirely distinguishable. All immanent attempts to achieve reliability or certainty in the confusing panorama of what is perceptible through reason, are always susceptible and fragile. Only the Christian faith provides a firm ground for orientation, albeit one who's truth cannot be proved. It is a truth, however, (and this is the punchline of Lope's play) that can be read to a certain degree from historical reality by anyone who has 'eyes to see.' The fact that Ginés' conversion is true and not a play is authenticated by the typological structure inscribed in the play, or by its extension, which has to be provided by the audience beyond the play's framenwork of action. The actual conversion of the Diocletian Empire fallen into vice authenticates the conversion of the licentious actor Ginés as a kind of 'preliminary stage' ('umbra') of veritas. It is interesting to note that Calderón's drama also equates faith and truth by referring to history, although more covertly than in Lope de Vega. It is possible that Calderón chose to situate his play in Poland, the kingdom of Segismundo, because it was well-known at the time that Poland had turned away from the Protestant "heresy" (symbolized by Basilio) and back to the 'only true' Catholic faith. By using (world) history to supplement the proof of truth, the two Spanish baroque playwrights shift the answer to the questions: What is true? What is illusion? to the Last Day. No matter how many defeats truth (faith) suffers, this cannot invalidate the answer the plays give to

der Endzeit und des wahren Gottesreiches. So bleibt das Geschehen in all seiner sinnlichen Kraft doch immer Gleichnis, verhüllt und deutungsbedürftig, wenn auch die allgemeine Richtung durch den Glauben gegeben ist” [p. 80]). For the aspect of figural interpretation, cf. in total pp. 49-76 (pp. 74-92), apart from the quoted passages, furthermore, esp. pp. $53 \mathrm{ff}$. (pp. 77 f.); for Adam as figura Christi, see pp. 28 ff. (p. 65), for the Church Fathers' phenomenal prophetic interpretation of the Old Testament, see pp. 28-49, esp. pp. $42-49$ (pp. 65-74, esp. pp. 70-74). 
the question of truth and can only be seen - as in the gruesome death of the converted Genius - as prelude to future triumphs.

After Lope's Lo fingido verdadero, the Genesius legend appeared in another Spanish drama in the $17^{\text {th }}$ century: El mejor representante, San Ginés [The Greatest Actor, Saint Genesius]. Written by Jerónimo de Cáncer, Pedro Rosete Niño, and Antonio Martínez de Meneses, likely before 1655, it appeared in 1668 in the Parte veinte y nueve de comedias nuevas, escritas por los mejores ingenios de España. ${ }^{660}$ Although based on the plot sketched in Lope's drama - the first act, for example, also deals with Diocleciano's rise to power - it was considerably modified. ${ }^{661}$ Despite all the presence of the theatrum mundi themes (using direct quotations from Lope and Calderón), the interplay of fingido and verdadero that was the heart of Lope's drama is rendered irrelevant. Rather, the play is characterized by a "dimensión plenamente hagiográfica," as Cattaneo puts it. ${ }^{662}$ This is underscored, for instance, by the numerous 'interventions of heaven' (a total of seven 'miraculous apparitions' are represented). The final scene even shows

660 Jerónimo Cáncer/Pedro Rosete/Antonio Martínez, El mejor Representante San Gines, in: Parte veinte y nueve de comedias nuevas, escritas por los mejores ingenios de España, Madrid 1668, pp. 188 [i.e. 189]-230.

661 Only a few points shall be mentioned: At the beginning of the play, Diocleciano, his sister (!) Camila (she is in love with Ginés), Ginés, and his friend Julio (the gracioso of the comedia) are soldiers in the Roman army who return to Rome after an absence of six years, where Apro, after the death of Aurelio and Numeriano, has become emperor. The difference in the way of representation is striking, as past events are relayed by Ginés in long monologues. Diocleciano is appointed emperor by the soldiers, but also through 'supernatural intervention.' A relevant addition is the character of Policarpo: an old comedy poet (he is the author of the play 'El cristiano bautizado') and a Christian, who is at first an enemy of Ginés (who is explicitly identified as an enemy of Christians) then - after the latter's miraculous conversion - as his 'mentor.' Furthermore, it is noteworthy that Ginés is not initially an actor. After the current emperor 'rids himself of' his old friends and they leave the army, he and Julio take up this profession in order to earn money and, as far as Ginés is concerned, for reasons of love: He recognizes in the famous actress Marcela that unknown beauty whom he had once fallen for and begins a relationship with her. (Immediately after having rejected Camila in the first act, Ginés sees a beautiful woman in a garden near the Tiber, reading verses from a piece of paper and repeating them, but the appearance of an old man dressed in fur - Policarpo, as it turns out later shouting to him: 'You shall become a Christian,' prevents an approach). Marcela converts as well and, like Policarpo, too, will die a martyr's death.

662 Cattaneo, "La doctrina dramática en Lo fingido verdadero y su proyección europea" (cf. note 494), p. 191. See as well Maria Teresa Cattaneo, "Una nota per El mejor representante, di Géronimo Cáncer, Pedro Rosete e Antonio Mártinez," in: Lope de Vega, Lo fingido verdadero (cf. note 487), pp. 43-50, and Cattaneo, “Transformaciones de Ginés, actor y mártir” (cf. note 494), pp. 262-267. 
a Genesius pierced by a lance on a cross in the middle of a theater, ${ }^{663}$ to the sound of music an angel descends and adorns him with a laurel branch "[...] en prueba de que ganaste / con el Sumo Autor el nombre / del mejor Representante." 664 The theater imagery continues: Ginés is given 'eternal applause' ("Y con eterno aplauso, / Gines, tu nombre canten / en diuinos acentos / los Coros celestiales.”665), and the martyr's last words are: "Zelo, fe, y constancia en este / teatro bañado en sangre / he representado al pueblo.”666

Lo fingido verdadero is also regarded as the model for the even more prominent French adaptation of the Genesius story by Jean de Rotrou (1609-1650). ${ }^{667}$ Taking my analysis of Lope's text, and this study's overarching questions, I will now go on to discuss this play.

\subsection{Jean de Rotrou, Le Véritable Saint Genest (1645-46/1647)}

The tragedy Le Véritable Saint Genest [The Real Saint Genesius] was written in 1645 or 1646, and first printed in 1647. This was not Rotrou's first adaptation of a Spanish comedia for the French stage. ${ }^{668}$ Rotrou had already used plays from Lope's oeuvre as models and reworked them. For example: La Bague de l'oubli (premiered in 1629 and printed in 1635) is based on Lope's La sortija del olvido (1619), the tragi-comédie Les Occasions perdues (1635) on Lope's La ocasión perdida (1610), and Laure persecutée (premiered in 1637, published in 1639) on Lope's Laura perseguida (1614). 669

663 The stage direction reads: "Abrense unas puertas en el primer corredor y vease vna perspectiua redonda en forma de teatro y en medio, Gines en vna Cruz atrauessado de vna lanza" (Cáncer/Rosete/Martínez, El mejor Representante San Gines [cf. note 660], p. 230a).

664 P. 230b.

665 Ibid.

666 Ibid. (my italics).

667 This is already mentioned in Léonce Person, Histoire du Véritable Saint-Genest de Rotrou, Paris 1882, pp. 8 f.; see as well Menéndez Pelayo, "Lo fingido verdadero" (cf. note 489), pp. 270-282.

668 The most famous case is Pierre Corneille's (1606-1684) Le Cid (1637). The Spanish model for the subject was the comedia Las mocedades del Cid (1618) by Guillén de Castro (1569-1631). 669 Cf. Catherine Dumas, "Rotrou adaptateur de Lope de Vega: Réajustements structurels et transferts culturels," Littératures Classiques 63 (2007), pp. 45-58. According to her, seven of the 35 dramatic works written by Rotrou that we know of are "[...] des adaptations plus ou moins proches de comedias de Lope de Vega” (p. 45). Regarding this aspect, cf., furthermore, Gerda Schüler, Die Rezeption der spanischen Comedia in Frankreich in der 1. Hälfte des 17. Jahrhunderts: Lope de Vega und Jean Rotrou, Diss. Cologne 1966 (on Lo fingido verdadero and Le Véritable Saint Genest: pp. 106-130). For a discussion relating Lope's play analyzed here 
In terms of the subject matter of the play, the Genesius legend was known in France, as texts such as Lystoyre et la vie du glorieux corps saint Genis à XLIII personnages, a Mystère from the 15 th century, attest. ${ }^{670}$ In fact, shortly before Rotrou wrote his tragédie, Nicolas Mary, sieur Desfontaines (1610?-1652) wrote and performed his version in 1644/1645: L'Illustre Comédien ou le Martyre de Saint Genest. Unlike Rotrou's drama, however, Desfontaines' version, which will be discussed later in the course of the analysis, does not make use of Lope's Lo fingido verdadero. Given the close timing of the works, scholars occasionally argue that Rotrou chose the title 'Véritable' Saint Genest in order to differentiate his play from that of Desfontaines, especially since the last verses of the tragédie may have referred to a French translation of the Spanish original in the original title ('Le Feint véritable'): "MAXIMIN: [...] [I]l [Genest] a bien voulu, par son impiété, / D'une feinte, en mourant, faire une vérite." 671 In Rotrou there is only one, rather than two 'plays within the play.' Here called "Le martyre d'Adrian," it is believed to be an adaptation of the Sanctus Adrianus Martyr (1630) by French

and Rotrou's adaptation, cf. the already mentioned studies by Egginton (How the World Became a Stage [cf. note 494]); Frese Witt ("From Saint Genesius to Kean: Actors, Martyrs, and Metatheater" [cf. note 494]); Laemmel ("Zur Adaptation einer 'comedia de santo' in Frankreich" [cf. note 494]); Simerka ("Metaheater and Skepticism” [cf. note 2]; her argument has already been addressed above); Valis ("Rotrou and Lope de Vega: Two Approaches to Saint-Genest” [cf. note 494]). On Rotrou's drama, cf., moreover: Peter Bürger, "Illusion und Wirklichkeit im Saint Genest von Jean Rotrou," Germanisch-Romanische Monatsschrift 45 (1964), pp. 241-267; John D. Lyons, "Saint Genest and the Uncertainty of Baroque Theatrical Experience," Modern Language Notes 109 (1994), pp. 601-616; Robert J. Nelson, "Immanence and Transcendence in Le Véritable Saint Genest," in: Robert J. Nelson, Immanence and Transcendence: The Theater of Jean Rotrou (1609-1650), Columbus, OH 1969, pp. 19-38; Elida Maria Szarota, "Rotrous Le Véritable Saint-Genest," in: Szarota, Künstler, Grübler und Rebellen (cf. note 494), pp. 43-57. Cf. as well Daniel Weidner, "Der Heilige Genesius. Der Schauspieler als Märtyrer, der Märtyrer als Schauspieler,” in: Sigrid Weigel (ed.), Märtyrer-Porträts: Von Opfertod, Blutzeugen und heiligen Kriegern, Munich 2007, pp. 74-77.

670 L'Ystoyre et la vie de Saint Genis, ed. Wilhelm Mostert and Edmund Stengel, Marburg 1895; cf. as well the 'summary' in: Wilhelm Mostert, Das Mystère de Saint Genis, seine Quelle und seine Interpolatoren, Diss. Marburg 1894, pp. 31-38. Furthermore, cf. Egginton, How the World Became a Stage (cf. note 494), pp. 80-83.

671 Jean de Rotrou, Le Véritable Saint Genest, ed. François Bonfils and Emmanuelle Hénin, Paris 1999, 5.7, vv. 1749 f. (my italics). References to the play are taken from this edition and, in the following, will be given in the main body of the text in parentheses, indicating act, scene, and verse numbers (verses are counted continuously throughout). The mentioned aspect concerning the title is also referred to by the editors of the edition used here (see pp. $122 \mathrm{f}$ ). 
Jesuit priest Louis Cellot. ${ }^{672}$ Unlike in Lope, Rotrou's internal play thus also makes use of a dramatic model. This internal martyr-play is elaborated here to a much greater extent and covers twelve scenes of the entire tragedy, distributed over the second, third, and fourth of the five acts (2.7-8, 3.2-7, and 4.2-5). Rotrou also dispenses with the dramatic representation of Diocletian's ascent from soldier to emperor given by Lope in the first jornada. Instead, the plot of Le Veritable Saint Genest begins at the imperial court in Rome (preserving the unity of place). Another difference is Rotrou's introduction into the plot of two additional characters, Valérie, Dioclétian's daughter, and her servant and confidante Camille. He also replaces Lope's Maximiano, Diocletian's co-Augustus, with Maximin, who is modeled after Diocletian's junior emperor Galerius (C. Galerius Valerius Maximianus) who was also married to Diocletian's daughter Valeria (in Rotrou, the character of Valérie). ${ }^{673}$

I begin by reviewing the play's plot line.

[1.] At the beginning of the first act, Valérie tells her servant Camille that she has been having a recurring dream in which her father forces her to marry a shepherd, and fears that it might be prophetic. Camille takes the (opposite) position that dreams are meaningless and have no influence on reality. Valérie's worries about her future, but her talk of suicide to protect herself from her father's inconstance lasts only until Dioclétian arrives. Accompanied by Maximin, with whom Valérie is in love, Dioclétian has returned victorious from the Orient and promptly declares his decision to appoint Maximin emperor by his side and to give him his daughter Valérie as his wife. Like Dioclétian, Maximin began life as a lowly shepherd before embarking on a military career and rising to emperor. Thus, Valérie's dream (that her father was going to marry her to a shepherd) does come to pass, although in a positive way. This image of the shepherd is an allusion, on the one hand, to the founding myth of Rome, which tells that Romulus and Remus were found and cared for by a shepherd, after initially being raised by a she-wolf. On the other hand, it also has heavy Christian connotations as well, specifically the image of the Good Shepherd. In Lo fingido verdadero, Diocleciano's rise to emperor is linked to a prophecy that was initially not taken seriously by the characters but which

672 Louis Cellot, Tragoedia Sanctus Adrianus Martyr, in: Louis Cellot, Opera poetica, Paris 1630, pp. 1-100. Thomas Frederick Crane provides a list of parallel passages: Jean Rotrou's Saint Genest and Vencelas, ed., introd. and notes by T. F. Crane, Boston/New York 1907, pp. 365-369 (Appendix II). Cf. as well the translation of the argumentum in: Jean de Rotrou, Le Véritable Saint Genest, Tragédie, ed. José Sanchez, Mont-de-Marsan 1991, pp. 199-206, cf. as well pp. CI-CVIII.

673 On the Diocletian Tetrarchy, see above note 519. 
ultimately proves to be true, while in Rotrou it is represented in the form of a prophetic dream that becomes 'reality.'

The character of the famous actor Genest appears before the imperial court in the fifth scene of the first act, when Dioclétian commissions him to perform a play in honor of his daughter Valérie's wedding. He praises Genest's acting, his impact on the good reputation the theater now enjoyed, his various characters, his convincing and moving performances in both tragic and the comic genre, and refers to the power of comedy as an effective means against sadness, ${ }^{674}$ before asking Genest about playwrights and works popular at the moment. Genest speaks about the diversity of tastes, noting that his preference was not for contemporary authors ('les Modernes'), but for Plautus, Terence and the Greek poets ('les Anciens'). Dioclétian, on the other hand, prefers the former. Valérie notes that Genest's acting is always convincing and fascinating, regardless of the material he presented. He was truly inimitable, however, in his role of a Christian martyr ("Mais on vante surtout, l'inimitable adresse, / Dont tu feins d'un chrétien le zèle et l'allégresse, / Quand le voyant marcher du baptême au trépas, / Il semble que les feux soient des fleurs sous tes pas” 1.5, vv. 293-296). Genest gladly complies with Valérie's wish that he put on a parody of the madness of Christian martyrs, provided that Maximin agrees to appear in the play ("Si votre nom, Seigneur, nous est libre en la scène;" 1.5, v. 298), which was to be "[L]a mort d'Adrian" (v. 299). Adrian was one of those stubborn Christians who had recently been sentenced following Maximin's decrees, and this event, Genest adds, would be presented with such great art and would reflect reality in such a way that he, Maximin, would grant them the freedom 'to represent the emperor before the emperor's eyes,' that is, see himself so embodied on stage that he would even ask himself whether he was witnessing a real event or only watching a play:

Et la mort d'Adrian, l'un de ces obstinés,

Par vos derniers arrêts naguère condamnés,

Vous sera figurée avec un art extrême,

674 "DioclÉtian: Avec confusion j’ai vu cent fois tes feintes, / Me livrer malgré moi de sensibles atteintes; / En cent sujets divers, suivant tes mouvements, / J'ai reçu de tes feux de vrais ressentiments; / Et l'Empire absolu que tu prends sur une âme, / M'a fait cent fois de glace, et cent autres de flamme: / Par ton art les héros plutôt ressuscités, / Qu'imités en effet, et que représentés, / Des cent et mille ans après leurs funérailles, / Font encor des progrès, et gagnent des batailles, / Et sous leurs noms fameux établissent des lois; / Tu me fais en toi seul maître de mille rois. / Le comique, en ton art également succède, / Est contre la tristesse un si présent remède, / Qu'un seul mot, quand tu veux, un pas, une action, / Ne laisse plus de prise à cette passion, / Et par une soudaine, et sensible merveille, / Jette la joie au cœur, par l'œil ou par l'oreille" (1.5, vv. 233-250). 
Et si peu différent de la vérité même, Que vous nous avouerez de cette liberté, Où César à César sera représenté;

Et que vous douterez, si dans Nicomédie, Vous verrez l'effet même, ou bien la comédie.

Maximin agrees, saying: "Oui, crois qu'avec plaisir je serai spectateur / En la même action dont je serai l'acteur" (vv. 307 f.). Thus, at this point the play implies that fiction and reality, play and truth are closly related, and establishes the 'mirror character' of the inner play. The first and second levels of the play will be connected in the 'play within the play' not only by the fact that the actors are also actively involved in the framing play, but moreover by having an (inner) spectator appear as a character in the inner performance ('je serai spectateur / En la même action dont je serai l'acteur'). Maximin, the ruler who brought about the martyrdom of Adrian, will see himself fictionally portrayed by the actor Octave.

The 'play within the play's' plot portrays, as has already been mentioned, the life of Saint Adrian. According to the legend, Adrian was a senior official in the Roman army in Nicomedia under Emperor Galerius Maximianus ${ }^{675}$ who witnessed the profound faith of 23 Christians who despite intense torture did not renounce their beliefs and was therefore inspired to convert to Christianity himself and was promptly arrested. His wife Nathalia, herself a hidden Christian, hurried happily, according to the legend, to the condemned prisoner and encouraged him to endure torture in the name of faith. He is said to have died a martyr's death on September $8^{\text {th }}, 310$ CE (or earlier), with his wife Nathalia suffering the same fate a short while later. ${ }^{676}$

[2.] The second act begins with preparations for the performance of "Le martyre d'Adrian." While Genest is dressing for the performance, script in hand, he looks out at the stage and gives the stage designer final instructions.

675 He ruled during the years 293-311, between 293-305 as subordinate co-emperor of Diocletian, and between 305-311 as Augustus in the eastern part of the Empire.

676 Cf. Stadler et al. (eds.), Vollständiges Heiligen-Lexikon (cf. note 495), vol. 1, p. 45 ("Adrianus, Natalia"); cf. moreover "Acta S. Adriani et Sociorum Mart. [Die Octava Septembris]," in: Acta Sanctorum: Quotquot toto orbe coluntur [...], ed. Jean Bolland et al., 69 vols., Antwerp/Brussels 1643-1940, Acta Sanctorum: Septembris, ed. Johannes Stilting et al., vol. 3, Rome/Paris 1868 (1st ed. Antwerp 1750), pp. 218-232. Regarding the persecution of Christians under Diocletian, Galerius and the other Tetrarchs, see above note 625. Note that there is a possible anachronism with regard to the reference saints of the framing plot and the inner play, inasmuch as, according to the legend, Genesius' death presumably occurred before that of Adrian. 
He then repeats a passage from his role as Adrian by reciting aloud from the script. In the meantime, Marcelle, the actress portraying the character of Natalie, Adrian's wife, enters. Marcelle rehearses one of her passages under Genest's guidance, and he praises her for her successful performance. ${ }^{677}$ Genest then continues, alone again, with his own character preparation. He becomes so carried away by his performance (in the stage direction it says preparingly: "ayant un peu rêvé et ne regardant plus son rôle, il dit:"), that he feels himself Genest, not Adrian - to be a Christian. He also reflects on this obscuring of borders between fiction and reality, role and actor. He knew from experience that through constant practice the ability of actors to transform themselves becomes a habit. But what he was now experiencing seemed to him to go beyond this and to be an 'unvarnished truth' ("des vérités sans fard”):

\author{
Dieux, prenez contre moi ma défense et la vôtre; \\ D'effet, comme de nom, je me trouve être un autre; \\ Je feins moins Adrian que je ne le deviens, \\ Et prends avec son nom, des sentiments chrétiens. \\ Je sais, pour l'éprouver, que par un long étude \\ L'art de nous transformer, nous passe en habitude, \\ Mais il semble qu'ici, des vérités sans fard \\ Passent et l'habitude, et la force de l'art, \\ Et que Christ me propose une gloire éternelle, \\ Contre qui ma défense est vaine et criminelle; ${ }^{678}$
}

When he finally calls himself to reason: "Il s'agit d'imiter, et non de devenir" (2.4, v. 420), 'Heaven opens above him' and he hears a voice (stage direction: "Le ciel s'ouvre, avec des flammes, et une voix s'entend, [...].") that promises him that he will not play his role in vain, that his salvation depended only on having courage, and God would help him ("UnE Vorx: Poursuis Genest ton

677 What is important for him here is highlighting the emotions. Cf.: "GENEST: Avez-vous repassé cet endroit pathétique, / Où Flavie en sortant vous donne la réplique? / Et vous souvenez-vous qu'il s'y faut exciter? / [. . . / Outre que dans la Cour que vous avez charmée, / On sait que votre estime est assez confirmée; / Ce récit me surprend, et vous peut acquérir / Un renom au théâtre, à ne jamais mourir" (2.3, vv. 369-388; my italics).

678 And he continues: "J'ai pour suspects, vos noms de dieux et d'immortels, / Je répugne aux respects qu'on rend à vos autels; / Mon esprit à vos lois secrètement rebelle, / En conçoit un mépris qui fait mourir son zèle; / Et comme de profane, enfin sanctifié, / Semble se déclarer, pour un crucifié; / Mais où va ma pensée, et par quel privilège / Presque insensiblement, passai-je au sacrilège? / Et du pouvoir des dieux, perds-je le souvenir? / Il s'agit d'imiter, et non de devenir" (2.4, vv. 411-420). 
personnage, / Tu n'imiteras point en vain; / Ton salut ne dépend, que d'un peu de courage, / Et Dieu t’y prêtera la main” 2.4, vv. 421-424).

This 'divine voice' is highlighted by a shift from the French Alexandrine pattern to a four-verse stanza with three octosyllables and a dodecasyllable verse in second position in crossed rhyme. When compared to the corresponding rehearsal scene in Lope's play, it should also be pointed out whereas the spectators/readers of the Spanish play are granted an 'insight into heaven,' by having the 'inhabitants of the Christian heaven' visible above the stage, in Rotrou, this element is only indicated by the appearance of flames.

The astonished Genest reacts to what he has heard within the framework of Christian interpretation, thinking that heaven had taken care of him and asking God to show him the right way from now on. ${ }^{679}$ But he also expresses doubts about the status of what he has heard ("Mais, ô vaine créance et frivole pensée, / Que du Ciel cette voix me doive être adressée!” 2.4, vv. 433 f.). Was it merely a deception "[une] feinte voix" (v. 436)? He answers himself that the deception had been intended, that someone was responsible for it: "Quelqu'un s'apercevant du caprice où j'étais, / S'est voulu divertir par cette feinte voix, / Qui d'un si prompt effet m'excite tant de flamme, / Et qui m'a pénétré jusqu'au profond de l'âme" (2.4, vv. 435-438). He then calls on the pagan gods to take action against Christ and rejects Christ, declaring that his heart was unmoved and would remain steadfast, but he also calls upon Christ to continue the battle with the other gods (over him). ${ }^{680}$ The differences with the scene in Lope are important to note. For example, while in the latter play, especially in his dialogue with Fabio, Ginés' doubts intensify about whether he had heard an actual voice from heaven, or it had been an illusion, or perhaps the voice of another actor looking to give Ginés a cue. Genest's ambiguity, however, is fairly short lived and he quickly interprets what he had heard as a 'joke' made by one of his colleagues. Nevertheless, he still considers the possibility that he was actually inwardly touched by the Christian God and could become a Christian by opposing the power of the pagan gods to that of the Christian God. He is at first

679 “GenEST: Qu'entends-je, juste ciel, et par quelle merveille, / Pour me toucher le cœur, me frappes-tu l'oreille? / Souffle, doux et sacré, qui me viens enflammer, / Esprit saint et divin, qui me viens animer, / Et qui me souhaitant, m'inspires le courage, / Travaille à mon salut, achève ton ouvrage; / Guide mes pas douteux dans le chemin des Cieux, / Et pour me les ouvrir, dessille-moi les yeux" (2.4, vv. 425-432).

680 "GENEST: Prenez, dieux, contre Christ, prenez votre parti, / Dont ce rebelle cœur s'est presque départi; / Et toi, contre les dieux, ô Christ, prends ta défense, / Puisqu’à tes lois, ce cœur fait encor résistance; / Et dans l'onde agitée où flottent mes esprits, / Terminez votre guerre, et m'en faites le prix; / Rendez-moi le repos dont ce trouble me prive” (2.5, vv. 439-445). 
steadfast in his fidelity to the pagan gods and against Christ, but then interprets himself and his conviction of faith as the 'battlefield' of divine powers. This aspect of pitting the pagan gods against the new Christian faith does not appear at this point in Lope's version.

Then the décorateur enters in order to light the candles and informs Genest of the arrival of the audience. Genest comments that this is a "rôle glorieux" that he had presented before none other than the "cour des cieux;" the role was of the utmost importance to him, the object, the goal was heaven itself. ${ }^{681}$ The decorator then remarks: "Il repassait son rôle, et s'y veut surpasser" (2.5, v. 452).

While the audience - Dioclétian, Maximin, Valérie, and Camille, as well as the prefect Plancien - wait for the performance to begin, they praise the genre of tragedy and the quality of contemporary theater. ${ }^{62}$ Maximin sums up the play they are about to see: the contempt Adrian, once a man he held in the highest favor and affection, had shown for him and the gods, and the consequence of his stubborn insistence in the Christian faith. He is going to watch the portrayal of the traitor's death with equanimity, even if not "en sa personne," but at least "en sa figure" (2.6, v. 474). For his part Dioclétian notes that thanks to Genest's acting, they were all set for a good performance (cf. 2.6, v. 475).

The seventh scene of the second act then marks the beginning of the "play within the play.' Genest, in the role of Adrian, is alone on stage ("sur le théâtre élevé") and begins a monologue in which he recounts how he recently became a Christian, and encourages himself to endure the torture about to be inflicted. His greatest pain, however, was to lose his beloved wife Natalie. The next scene of the inner play consists of Adrian's confrontation with the tribune Flavie, played by the actor Sergeste. Flavie's attempts to persuade Adrian to renounce Christ fail. He accuses him of ingratitude towards the Emperor Maximin, mentions the latter's anger and that of the gods, appeals to his love and his sense of responsibility towards his wife Natalie. Adrian reaffirms his new faith and his willingness to die for it, and Flavie has him put in chains and led off. With this, the first part of the inner play ends. The following two very short scenes show the internal audience's enthusiasm over Genest's acting and their desire to use the break to congratulate the actors, while Maximin remarks that he is looking forward to the upcoming representation of himself.

681 "GENEST: [...] tu m'as distrait d'un rôle glorieux, / Que je représentais devant la cour des cieux; / Et de qui l'action, m'est d'importance extrême, / Et n'a pas un objet moindre que le Ciel même" (2.5, vv. 447-451).

682 Cf. 2.6, vv. 453-463 (e.g. "VALÉRIE: L'objet en [dans la tragédie] est plus haut, l'action plus hardie;" vv. 453 f.). 
[3.] With Act 3, scene 2, the second part of the performance of Le martyre d'Adrian begins. The first scene describes the renewed refusal of revocation (typical for the structure of the martyrs' vita): a bound Adrian renews his Creed before Emperor Maximin (played by Octave). Maximin, furious with rage, has Adrian thrown into prison and orders him to be cruelly tortured. Flavie hands Adrian over to the jailer (3.4). In the next scene (3.5), Adrian is visited by his wife Natalie (played by Marcelle). Flavie arranged the meeting in the hope that Natalie would change Adrian's mind and persuade him to recant. Adrian, however, dissolves the marriage with Natalie and releases her. As a converted Christian he now regards her as his sister ("Ma sœur, c'est le seul nom dont je te puisse nommer, / Que sous de douces lois nous nous pourrions aimer!” 3.5, vv. $845 \mathrm{f}$.). Natalie reveals to him, however, that she herself is also a Christian. She had been raised as a Christian from birth, but out of fear and respect for him had always kept her true faith hidden. Their marital love grows anew: "Ô Ciel, Ô Natalie! Ah! [Douce et] sainte flamme, / Je rallume mes feux, et reconnais ma femme; / Puisqu'au chemin du Ciel, tu veux suivre mes pas, / Sois mienne, chère épouse, au-delà du trépas” (3.5, vv. 859-862), moreover:

NATALIE: Partageons donc la peine, aussi bien que les crimes,

Si ces fers te sont dus, ils me sont légitimes,

Tous deux dignes de mort, et tous deux résolus,

Puisque nous voici joints, ne nous séparons plus;

Qu'aucun temps, qu'aucun lieu, jamais ne nous divisent,

Un supplice, un cachot, un juge, nous suffisent.

(3.5, vv. 923-928)

Adrian then asks Natalie to help him get through what lies ahead, by speaking of how he is following the divine order: everyone's time on earth is limited, and one dies for true faith when one is by God (cf. 3.5, vv. 929-939). Natalie then promises Adrian that she would support him in enduring martyrdom steadfastly until his death, his salvation, and accompany him to his execution, and she wishes to be able to follow him in this act. ${ }^{63}$ Natalie then explains to Flavie (3.6) that she could not persuade her husband to abandon his conversion. She tells him a different story of what took place between her and Adrian

683 "NATALIE: Bien donc, choisis le ciel, et me laisse la terre. / Pour aider ta constance, en ce pas périlleux, / Je te suivrai partout, et jusques dans les feux; / Heureuse, si la loi qui m’ordonne de vivre, / Jusques au ciel enfin me permet de te suivre; / Et si de ton tyran le funeste courroux / Passe jusqu'à l'épouse, ayant meurtri l'époux. / Tes gens me rendront bien ce favorable office, / De garder qu'à mes soins césar ne te ravisse, / Sans en prendre l'heure, et m'en donner avis; / Et bientôt de mes pas, les tiens seront suivis; / Bientôt ... " (3.5, vv. 940-951). 
and pretends that she regrets not being able to convince him to recant (cf. 3.6, vv. 959-974, 979-992). When she is alone (3.7), she thanks God for the conversion of her husband, exhorts herself to make her faith public as well, and expresses her aspiration to die a martyr's death. After Natalie (Marcelle) has left the stage, the performance is interrupted by Genest, who complains about an annoying noise, and Dioclétian wishes to ensure peace and quiet. This short scene concludes the third act.

[4.] The fourth act begins with the return of Dioclétian and the court to their seats and the performance continues (4.2). Flavie informs Adrian that Emperor Maximin wants to give him one last opportunity to recant. Adrian refuses, saying that God was his only ruler, he did not fear the cruel death awaiting him, he had long been active in the service of hatred as a persecutor of Christians and had seen the persistence of the Christians while he commanded their torture; his only wish was to be allowed to see his wife again in solitude before the execution. Flavie grants him this wish. Adrian goes to Natalie (4.5) but when she sees him alone and without chains (4.6), she concludes that he had decided against martyrdom and renounced the Christian faith. She fends him off and insults him (several times "traître," "perfide," "ennemi de Dieu," "lâche," "infâme,” etc.), his punishment for this deception would await him in hell ("Contre toi dans le ciel, Christ arme sa justice; / Les ministres d'enfer préparent ton supplice;” 4.4, vv. $1131 \mathrm{f}$.). ${ }^{684}$ Natalie's doubts about Adrian's sincerity and the truth of his conversion, caused by his appearance, her 'pretense of false facts' in her conversation with Flavie, and her concealment of her true faith, all highlight the problematic distinction between fake and real in the 'play within the play' of $L e$ Véritable Saint Genest. Adrian quickly clears up the misunderstanding, saying: "Je te vais détromper [...]" (4.4, v. 1140) and explains to Natalie the authenticity of his conversion and his wish to die a martyr's death (cf. 4.4, vv. 1147-1166). The latter apologizes to her "cher et généreux frère" (4.4, v. 1167) for her anger about the 'unjustified impression' (“[l]'injuste impression”), the wrong interpretation of what she saw (cf. vv. 1167-1170). Both now address each other again as brother/ sister for they are siblings in faith. Natalie now encourages Adrian to leave behind the vanities of the world in favor of heavenly glory, to die as in Christ with his head held high and receive "par un moment de mal l'éternité d'un bien" (v. 1194). She asks the priest Anthyme, an old Christian played by Lentule, to join her in encouraging Adrian ("Approche, cher Anthyme, et joins tes vœux aux

684 Cf. as well: “[Elle sort furieuse, et dit en s'en allant:] Que ferai-je, ô Seigneur! Puis-je souffrir sans peine / L'ennemi de ta gloire, et l'objet de ta haine! / Puis-je vivre, et me voir en ce confus état, / De la sœur d'un martyr, femme d'un apostat? / D'un ennemi de Dieu, d'un lâche, d'un infâme?" (4.4, vv. 1135-1139). 
miens" 4.4, v. 1214). When Adrian asks Anthyme to baptize him, ${ }^{685}$ he replies that water baptism was not a necessity for salvation for a future martyr, since he received the seal of God through his blood ('blood baptism'). ${ }^{686}$

After these words, Adrian looks up to heaven lost in thoughts (stage direction: "Adrian, regardant le ciel et rêvant un peu longtemps, dit enfin:"). The speech that follows is spoken by Genest not in his stage role of the converted Christian Adrian, but as himself: play and reality merge into each other. He addresses Lentule by his real name and not as Anthyme, the name of the character he is protraying. Genest says that he feels compelled to 'take off the mask' and reveal his thoughts to him. The God, whom he once hated, now filled him with his love. He says explicitly that it was no longer Adrian who was speaking, but Genest. Not Adrian, but he, Genest, was asking for the grace of baptism and the honor of martyrdom:

Ah! Lentule! En l'ardeur dont mon âme est pressée,
Il faut lever le masque, et t’ouvrir ma pensée;
Le Dieu que j'ai haï, m'inspire son amour,
Adrian a parlé, Genest parle à son tour!
Ce n'est plus Adrian, c'est Genest qui respire,
La grâce du baptême, et l'honneur du martyre;

Christ had not entrusted his (Lentule/Anthyme) profane hands with performing the baptism ("Mais Christ n'a point commis à vos profanes mains, / Ce sceau mystérieux, dont il marque ses saints;” 4.5, vv. 1249 f.). These words are accompanied by flames roaring from heaven (stage direction: "Regardant au ciel d'où l'on jette quelques flammes."). According to Genest, he sees an angel ready to baptize him ("Un ministre céleste, avec une eau sacrée, / Pour laver mes forfaits, fend la voûte azurée; / Sa clarté m’environne, et l'air de toutes parts, / Résonne de concerts, et brille à mes regards” 4.5, vv. 1251-1255). Speaking to the angel he begs him to come down, calls him a "céleste acteur" who has been

685 “ADRIAN: Mes vœux arriveront à leur comble suprême, / Si lavant mes péchés de l'eau du saint baptême, / Tu m'enrôles au rang de tant d'heureux soldats, / Qui sous même étendard ont rendu des combats; / Confirme, cher Anthyme, avec cette eau sacrée, / Par qui presque en tous lieux la croix est arborée, / En ce fragile sein, le projet glorieux, / De combattre la terre, et conquérir les cieux” (4.5, vv. 1231-1238).

686 “ANThymE: Sans besoin, Adrian, de cette eau salutaire, / Ton sang t'imprimera ce sacré caractère; / Conserve seulement une invincible foi; / Et combattant pour Dieu, Dieu combattra pour toi" (4.5, vv. 1239-1242). On the aspect of 'blood baptism,' cf. Thomas Aquinas, Summa theologica III $^{\mathrm{a}}$ q. 66 a. 12 (Aquinas, Summa [Latin] [cf. note 347], vol. 29 [1935], pp. 197 ff.; Aquinas, Summa [English] [cf. note 347], vol. 4, pp. 2385 f.). 
calling him to come to him and was awaiting him, as he finally goes behind the scenery. ${ }^{687}$ Both the actors on stage and the inner spectators comment on and interpret what has happened. Marcelle points out the deviation from the text and Lentule suspects that Genest had a lapse of memory/made a mistake that he wants to conceal by leaving the scene. ${ }^{68}$ Dioclétian and Valérie, on the other hand, classify it as a successful trick by the brilliant actor Genest ("DiocL.: Voyez avec quel art, Genest sait aujourd'hui, / Passer de la figure, aux sentiments d'autrui. / VAL.: Pour tromper l'auditeur, abuser l'acteur même, / De son métier, sans doute, est l'adresse suprême” 4.5, vv. 1261-1264). Then Flavie (Sergeste) enters the stage with guards (4.6) to bring Adrian back to prison ("FlAVIE: Ce moment dure trop, trouvons-le promptement; / César nous voudra mal de ce retardement; / Je sais sa violence, et redoute sa haine" 4.6, vv. 1265 ff.). Marcelle interrupts this 'continuation of the script' and explains to Sergeste what she thinks happened: "Cet homme si célèbre en sa profession, / Genest, que vous cherchez, a troublé l'action, / Et confus qu'il s'est vu, nous a quitté la place” (4.6, vv. 1269 ff.). Sergeste defends his colleague. ${ }^{689}$ This short scene, showing the confusion that Genest's exit caused among his fellow players, is again ascribed by the audience to Genest's extraordinary art ("CAMILLE, riant, $\grave{a}$ Valérie: Comme son art, Madame, a su les abuser!” 4.6, vv. 1274).

It is worth recalling at this point the baptism scene in the Spanish original. There, an angel appears and calls Ginés to him. Ginés follows the call and is baptized above the stage. For both the inner audience and the spectators/readers, this is indicated by the actual appearance of angels with baptismal equipment above the stage. Rotrou's Genest, however, only tells that he sees an angel calling him to be baptized. In the inner play in Lo fingido verdadero, the confusion on the stage, which also reaches the internal spectators, and the intensification of the question of what was play and what was (already) serious, result above all from the fact that the actor Fabio later appears in the role of the angel in order to perform the baptism (again) as it was intended in the play. Rotrou did not adopt this element of the embodiment of an angel on stage and the associated intensification of the blurring of the boundaries between theatrical fiction and reality.

687 "Descends, céleste acteur; tu m’attends! Tu m’appelles! / Attends, mon zèle ardent me fournira des ailes; / Du Dieu qui t'a commis, dépars-moi les bontés” (4.5, vv. 1255 ff.; the stage direction says: "Il monte deux ou trois marches et passe derrière la tapisserie.").

688 "MARCELLE, qui représentait Natalie: Ma réplique a manqué; ces vers sont ajoutés. / LENTULE, qui faisait Anthyme: Il les fait sur le champ; et sans suivre l'histoire, / Croit couvrir en rentrant son défaut de mémoire" (4.5, vv. 1258 ff.).

689 "Flavie, qui est Sergeste: Le plus heureux, parfois, tombe en cette disgrâce; / L'ardeur de réussir, le doit faire excuser" (4.6, v. 1271 f.). 
When Genest returns to the scene (4.7), he addresses heaven, praising the Christian God and baptism, as the covenant between him, the human being, and God, and the divine love that gives him "la force et l'ardeur d'un martyr," 690 the spectators continue to display great enthusiasm for his perfect embodiment of a baptized Christian. They remark that the performace was so well done that feinte and verité were indistinguishable ("MAX.: Il feint comme animé des grâces du baptême. / VAL.: Sa feinte passerait pour la vérité même. / Plancien: Certes, ou ce spectacle est une vérité, / Ou jamais rien de faux ne fut mieux imité” 4.7, vv. 1283-1286). Genest then turns to Marcelle (Natalie) and Sergeste (Flavie), addressing them by their real names, saying: so many times they had together mocked the Christian faith and the rites of the Christians, but now, for the sake of their souls' salvation, they, too, should refrain from mocking a God who died on the cross for them, adding that his own heart was now enlightened by heavenly grace. ${ }^{691}$ The two actors once again point out Genest's extensive deviation from the text, and one even calls for the prompter. Genest replies that this would not be necessary, since in this plot, which was in the interest of heaven, an angel was holding the script ready, acting as his prompter, and had fulfilled his longing, as the grace of baptism had been granted to him ("Il n'en est plus besoin. / Dedans cette action, où le ciel s'intéresse, / Un ange tient la pièce, un ange me redresse; / Un ange par son ordre, a comblé mes souhaits, / Et de l'eau du baptême, effacé mes forfaits;" 4.7, vv. 1298-1302). And he then continues, still employing imagery from the world of acting and the theater, particularly the concept of theatrum mundi, that the world was perishable and void, "une comédie où j'ignorais mon role" (4.7, v. 1304; my italics). He declares that he had been following the devil's play so far, but now, since he was taught and guided by a heavenly spirit, he had corrected his role and repented of his sins, and heaven, having seen his tears, had taken pleasure in this action and granted him its grace, so that he had now become its actor:

690 “GENEST: Suprême Majesté, qui jettes dans les âmes / Avec deux gouttes d'eau, de si sensibles flammes, / Achève tes bontés, représente avec moi / Les saints progrès des cœurs convertis à ta foi! / Faisons voir dans l'amour, dont le feu nous consomme, / Toi le pouvoir d'un dieu, moi le devoir d'un homme; / Toi l'accueil d'un vainqueur, sensible au repentir, / Et moi, Seigneur, la force et l'ardeur d'un martyr" (4.7, vv. 1275-1282).

691 "GENEST: Et vous, chers compagnons de la basse fortune / Qui m'a rendu la vie avecque vous commune, / Marcelle, et vous Sergeste, avec qui tant de fois, / J'ai du dieu des chrétiens scandalisé les lois, / Si je puis vous prescrire un avis salutaire, / Cruels, adorez-en jusqu'au moindre mystère, / Et cessez d'attacher avec de nouveaux clous / Un dieu, qui sur la croix daigne mourir pour vous, / Mon cœur illuminé d’une grâce céleste ... ” (4.7, vv. 1287-1295). 


\author{
Ce monde périssable, et sa gloire frivole, \\ Est une comédie où j'ignorais mon rôle; \\ J'ignorais de quel feu mon coeur devait brûler \\ Le démon me dictait, quand Dieu voulait parler; \\ Mais depuis que le soin d'un esprit angélique \\ Me conduit, me redresse, et m'apprend ma réplique, \\ J'ai corrigé mon rôle, et le démon confus, \\ M'en voyant mieux instruit, ne me suggère plus; \\ J'ai pleuré mes péchés, le ciel a vu mes larmes, \\ Dedans cette action, il a trouvé des charmes, \\ M'a départi sa grâce, est mon approbateur, \\ Me propose des prix, et m'a fait son acteur.
}

In order to make sense of this bewildering scene, Lentule again refers to improvisation. But Genest makes it clear: he was speaking God's words, and it would be a misapprehension to think he was still acting ("Dieu m'apprend sur le champ, ce que je vous récite; / Et vous m'entendez mal, si dans cette action, / Mon rôle passe encor pour une fiction" 4.7, vv. 1316 ff.). At this point the boundary between the first and second play levels is also transgressed, as the internal spectators and the actors on stage interact. Dioclétian expresses his indignation at the incomprehensible confusion on stage and admonishes that they should show more respect for his imperial presence. Thereupon, Genest once again explicitly confesses himself to be a Christian ("enfin je suis chrétien" 4.7, v. 1358), stating that he was not speaking as Adrian but as Genest, and that the play was no longer a play but had become reality:

\footnotetext{
Ce n'est plus Adrian, c'est Genest qui s'exprime;

Ce jeu n'est plus un jeu, mais une vérité,

Où par mon action je suis représenté,

Où moi-même l'objet et l'acteur de moi-même,

Purgé de mes forfaits par l'eau du saint baptême,

Qu'une céleste main m'a daigné conférer,

Je professe une loi, que je dois déclarer.
}

(4.7, vv. 1324-1330)

Furthermore, and this is a striking difference to Lope's Genesius, he gives a detailed account of his life to date as an enemy of Christians, saying that he had always hated Christians deeply and had left his parents' house and his homeland in order to use his acting skills primarily for their defamation, etc. Now however, his own conversion had been brought about by a divine miracle. He then goes on to describe the miracle of his conversion and the baptism 
extensively. ${ }^{692}$ At the end of his speech, he expresses the desire to die a martyr's death, because it was the soul not the body that is important and he does not fear torture and death, because they will lead to (real) life. ${ }^{693} \mathrm{He}$ opposes his previous acting services to Dioclétian with true action in the service and honor of God, that the time had come, "de passer du théâtre aux autels" (v. 1370), that he expects martyrdom and that his role (here) has come to an end:

\footnotetext{
J'ai souhaité longtemps d'agréer à vos yeux, Aujourd'hui je veux plaire à l'empereur des cieux; Je vous ai divertis, j'ai chanté vos louanges; Il est temps maintenant de réjouir les anges, Il est temps de prétendre à des prix immortels, Il est temps de passer du théâtre aux autels; Si je l'ai mérité, qu'on me mène au martyre; Mon rôle est achevé, je n'ai plus rien à dire.
}

Dioclétian calls his performance presumptuous causing Genest to reaffirm the truth of what he has said. After he mockingly and explicitly renounces the pagan gods once again, Dioclétian angrily orders the death of the "traître" (4.7, v. 1377) and "insolent" (v. 1385), also invoking theatrical metaphors, saying that Genest's action should be brought to an end with an "acte sanglant" (v. 1386), "[q]ui vécut au théâtre, expire sur la scène;” (v. 1388). The 'play within the play' is now over. Marcelle's request for mercy is immediately rejected by Dioclétian. The

692 Cf. 4.7, vv. 1331-1358 ("Écoutez donc, Césars, et vous troupes romaines, / La gloire et la terreur des puissances humaines, / Mais faibles ennemis d'un pouvoir souverain / Qui foule aux pieds l'orgueil et le sceptre romain; / Aveuglé de l'erreur dont l'enfer vous infecte, / Comme vous, des chrétiens j'ai détesté la secte; / Et si peu que mon art pouvait exécuter, / Tout mon heur consistait à les persécuter; / Pour les fuir, et chez vous suivre l'idolâtrie, / J'ai laissé mes parents, j'ai quitté ma patrie; / Et fait choix à dessein d'un art peu glorieux, / Pour mieux les diffamer, et les rendre odieux; / Mais par une bonté qui n'a point de pareille, / Et par une incroyable et soudaine merveille / Dont le pouvoir d'un dieu, peut seul être l'auteur, / Je deviens leur rival de leur persécuteur, / Et soumets à la loi que j'ai tant réprouvée / Une âme heureusement de tant d'écueils sauvée; / Au milieu de l'orage, où m'exposait le sort, / Un ange par la main, m'a conduit dans le port, / M'a fait sur un papier voir mes fautes passées / Par l'eau qu'il me versait, à l'instant effacées; / Et cette salutaire et céleste liqueur, / Loin de me refroidir, m’a consommé le cœur. / Je renonce à la haine, et déteste l'envie / Qui m’a fait des chrétiens, persécuter la vie; / Leur créance est ma foi, leur espoir est le mien, / C'est leur dieu que j'adore, enfin je suis chrétien;").

693 “Quelque effort qui s'oppose, en l'ardeur qui m’enflamme, / Les intérêts du corps, cèdent à ceux de l'âme, / Déployez vos rigueurs, brûlez, coupez, tranchez, / Mes maux seront encor moindres que mes péchés; / Je sais de quel repos cette peine est suivie, / Et ne crains point la mort, qui conduit à la vie;” (4.7, vv. 1359-1364). 
court leaves the theater. In response to Camille's comment that he was foolish to despise the Emperor's favor in such a way, Genest replies that in doing so he had received the divine grâce. Ultimately, he is led off by the guards and, full of joy, looks forward to his reward for his imminent martyrdom in the world to come.

In the next scene (4.9), Plancien interrogates the actors, because "Sa [Genest's] foi, comme son art, vous est-elle commune? / Et comme un mal, souvent, devient contagieux ... " (4.9, vv. $1498 \mathrm{f}$.). They assert that they are not Christians. As in Lope's drama, the actors are asked about their acting repertoires. ${ }^{694}$ Plancien considers them to be 'honest' (even naive: "Leur franchise ingénue, / En leur naïveté, se produit assez nue;” vv. 1419 f.), he feels sorry for them and, moreover, allows them to try to convince Genest to revoke his new faith, so that the acting company is not deprived of its director and can continue to exist.

[5.] The final act opens with Genest, sentenced to death, bound and imprisoned. Preparing himself for his impending torture and death, he contrasts it with the nothingness, deception, and "fausse volupté" (v. 1441) of earthly existence, he sings (in four stanzas of ten octosyllabic verses each) about the delights of heaven awaiting him and the glory of martyrdom. Marcelle comes to his cell (5.2) with the aim of persuading him to recant and using every conceivable argument: if not do it for his own sake, then at least for them, the other actors, who ultimately all depend on him (cf. 5.2, vv. 1473-1486); the Christian faith was absurd (cf. 5.2, vv. 1495-1512); his acting talent would certainly earn him imperial fame. She further says that perhaps his decision, which was incomprehensible to her and whose authenticity she did not believe, was connected to his regrets over his youth, and that perhaps he had not received sufficient acknowledgment of his work from the court and the emperor, but their profession, although much admired, was an art in which merit was less important (cf. 5.2, vv. 1513-1540). If he could not or really did not want to recant, then he could at least fake his renunciation. The emperor's wrath would be alleviated by this deception, this would be of help to them, that he would only have to worship the (pagan) gods for the sake of appearance (cf. 5.2, vv. 1579-1586). Genest replies that his faith would not permit such a weakness, that he was compelled and wanted to openly profess his faith and profess God, that he had already used his art too many times to mock God and the Christians, and that he could no longer perform before idolaters (cf. 5.2, vv. 1587-1598). With regret he realizes that he had tried in vain to

694 A repertoire that turns out to be extremely varied, including extremes. Thus, Marcelle says she plays women, but also men (“[...] les femmes;/ Si selon le sujet, quelque déguisement, / Ne m'obligeait parfois au travestissement” 4.9, vv. $1412 \mathrm{ff}$.), Octave plays both kings and slaves (4.9, v. 1415), and Sergeste "[l]es extravagants, les furieux, les braves” (4.9, v. 1416). 
put an end to Marcelle's blindness, her 'false faith' (to convert her). Their art, acting, was not of such great importance that he had ever expected a great reward for it. He had had worldly glory on stage, but that glory had no relevance. God, to whom he owed his life, was the only one who could save him. Everyone could save their souls, but not everyone would accept the divine call, God's grace: "Ta grâce peut, Seigneur, détourner ce présage! / Mais hélas! Tous l'ayant, tous n’en ont pas l'usage; / De tant de conviés, bien peu suivent tes pas, / Et pour être appelés, tous ne répondent pas” (5.2, vv. 1575-1578). He had no fear of cruel death, the torments were of short duration, but his "gloire" was eternal (cf. 5.2, v. 1600) and speaks about the Christian concept of the immortality of the soul, of the true life after death, which is in contrast to the void, earthly life. ${ }^{695}$ Marcelle finally leaves Genest who remains affirmed in his faith ("MARC.: Ainsi rien ne te touche, et tu nous abandonnes. / GENEST: Ainsi je quitterais un trône et des couronnes; / Toute perte est légère, à qui s’acquiert un dieu” 5.2, vv. 1615 ff.). Thus, there is also on the level of the tragédie (as in the inner play) a detailed refusal on behalf of the Christian martyr to renounce his faith.

Genest is then taken by the geôlier to be executed, who metaphorically sets this in the context of the theater: "Si bientôt à nos dieux vous ne rendezvous hommage, / Vous vous acquittez mal de votre personnage; / Et je crains en cet acte un tragique succès" (5.4, vv. 1619-1621). Responding to the jailer, Genest speaks his last words in the play, in which he refers to divine judgment, the Christian concept of punishment and reward after death: "Un favorable juge assiste à mon procès; / Sur ses soins éternels, mon esprit se repose; / Je m'assure sur lui du succès de ma cause; / De mes chaînes par lui je serai déchargé, / Et par lui-même un jour, César sera jugé” (5.4, vv. 1622-1626).

In the next scene (5.5), Emperor Dioclétian reaffirms Maximin's ascent to imperial rule, and then goes on to address the 'question of the Christians.' Declaring his hope that a royal lineage will emerge from the marriage with his daughter Valérie and that Maximin's descendants, will, as he had done, earn themselves a place among the gods as a result of their glorious deeds. The gods, however, were the origin of the destinies of all men, on whom even the greatest ruler depended. It was the rulers' duty to ensure with all power and force that the gods were worshipped, their laws obeyed, and imperial authority respected. He had tried to enforce this in his territories by means of bloody deterrence

695 “GENEST: J’aurai bien peu vécu, si l'âge se mesure, / Au seul nombre des ans, prescrits par la nature; / Mais l'âme qu'au martyre un tyran nous ravit, / Au séjour de la gloire, à jamais se survit. / Se plaindre de mourir, c'est se plaindre d'être homme, / Chaque jour le détruit, chaque instant le consomme, / Au moment qu'il arrive, il part pour le retour, / Et commence de perdre, en recevant le jour" (5.2, vv. 1607-1614). 
against the Christians, but in vain: “J'en vois du sang d'un seul naître des légions" (5.5, v. 1650). His actions harmed the gods rather than benefited them, as from one beaten enemy a thousand new ones emerged. Furthermore, the Christians were of such a nature that death even encouraged them in their arrogance. The actor Genest, who had hitherto mocked and hated this "secte aussi folle que vaine" (5.5, v. 1655), had now adopted its doctrine and had the audacity to confess this before everyone's eyes. His contempt was for themselves, the rulers, and the gods. This had to be avenged by his death. Maximin confirms that they would make a public sacrifice out of it (v. 5, v. 1664), that the people would be given a "spectacle sanglant" (v. 1666) that very evening, "[s]i déjà sur le bois d'un théâtre funeste, / Il n'a représenté l'action qui lui reste” (vv. 1667 f.).

In the following scene (5.6), Valérie and the actors appear before Dioclétian to ask for his compassion and mercy for Genest. Valérie asks her father to pardon Genest, referring to her wedding day with Maximin, for the sake of the actors who all despised the faith to which Genest had turned, but could not continue without him. Marcelle, Octave, and Sergeste also beg the Emperor's forgiveness. Dioclétian emphasizes the state's obligation to bring Genest to his just punishment, but finally agrees to give the actor a last chance to turn back. It is, however, already too late. Plancien appears and reports that Genest has been executed, comparing the execution to the end of a tragedy:

\footnotetext{
Par votre ordre, Seigneur, ce glorieux acteur, Des plus fameux héros, fameux imitateur, Du théâtre romain, la splendeur et la gloire, Mais si mauvais acteur dedans sa propre histoire, Plus entier que jamais en son impiété, Et par tous mes efforts en vain sollicité, A du courroux des dieux, contre sa perfidie, Par un acte sanglant, fermé la tragédie.
}

(5.7, vv. 1717-1726)

Genest had endured his torture (which Plancien describes) with a force that was "plus qu'humaine" (v. 1735). This had been so impressive that "Nous souffrions plus que lui, par l'horreur de sa peine; / Et nos cœurs détestant ses sentiments chrétiens, / Nos yeux ont malgré nous fait l'office des siens;” (vv. 1736 ff.). Finally, he had been beheaded. Thus the tragedy had ended: "J'ai mis la tragédie, à sa dernière scène, / Et fait, avec sa tête, ensemble séparer, / Le cher nom de son dieu, qu'il voulait proférer" (5.7, vv. 1740 ff.). ${ }^{696}$

696 Plancien's report on Genest’s execution in its entirety: “J’ai joint à la douceur, aux offres, aux prières, / À si peu que les dieux m’ont donné de lumières, / Voyant que je tentais 
After that, everyone withdraws: Dioclétian is satisfied with this 'just and deterring punishment' (“Ainsi reçoive un prompt et sévère supplice / Quiconque ose des dieux irriter la justice” 5.7, vv. 1743 f.), while the actors and Valérie are crying, and Valérie expresses to Marcelle once again her sympathy for Genest ("Vous voyez de quel soin je vous prêtais les mains; / Mais sa grâce n'est plus au pouvoir des humains” vv. 1745 f.). Maximin emphasizes Genest's self-chosen fate, which Valérie should therefore not lament. The core of the Genesius-storyline, the turning of fiction into reality, is formulated in his closing lines: "Ne plaignez point, Madame, un malheur volontaire, / Puisqu'il l'a pu franchir, et s'être salutaire; / Et qu'il a bien voulu, par son impiété, / D’une feinte, en mourant, faire une vérité" (5.7, vv. 1747-1750; my italics).

As in the legend and in Lope's play, Rotrou's Genesius also dies a martyr's death at the end of the drama; feinte has become vérité. In comparing the two plays (apart from the general differences of the genre: Spanish [tragi]comedia with three jornadas versus French tragédie of five acts) attention should be drawn first to the different representation of the death of Ginés/Genest. While in Lo fingido verdadero Ginés death takes place on stage, in Rotrou, it is relayed in the thirdperson, through Plancien's account of the event. Placien relays the torture and superhuman endurance of the martyr, an important aspect of the typical story of a martyr that is missing in Lope's Lo fingido verdadero. In keeping with this, Rotrou also presents the martyr's repeated refusal to recant, which occurs in both the inner play and in the framing play. In addition, Genest is explicitly characterized as a former enemy of Christianity, another aspect elaborated on in Rotrou that becomes even more apparent by the mirroring in the play and the 'play within the play.' In this sense Rotrou's drama appears to be more strongly anchored in the original material of the legend of the martyr.

As has already been mentioned, Rotrou did not adopt Lope's focus on Diocletian's ascent from soldier in the Roman army to Augustus and the related agüero, which turns into burla verdadera. While in Lope's comedia the historical-political storyline covers an enormous range in terms of space, time, and dramatis personae, Le Véritable Saint Genest is characterized by reduction and

d'inutiles efforts / Tout l'art, dont la rigueur peut tourmenter les corps; / Mais ni les chevalets, ni les lames flambantes, / Ni les ongles de fer, ni les torches ardentes, / N'ont, contre ce rocher, été qu'un doux zéphyr / Et n’ont pu de son sein arracher un soupir; / Sa force, en ce tourment, a paru plus qu'humaine, / Nous souffrions plus que lui, par l'horreur de sa peine; / Et nos coeurs détestant ses sentiments chrétiens, / Nos yeux ont malgré nous fait l'office des siens; / Voyant la force enfin, comme l'adresse vaine, / J'ai mis la tragédie, à sa dernière scène, / Et fait, avec sa tête, ensemble séparer, / Le cher nom de son dieu, qu'il voulait proférer" (5.7, vv. 1727-1742). 
concentration. The action of the play takes place entirely in Rome ${ }^{697}$ : in the imperial palace (1.; 5.5-7), the theater (2.-4.), and prison (5.1-4), Dioclétian is already emperor. The framing plot centers around the imperial wedding, with the alliance of imperial power sealed by marriage and the gurantee of the emergence of a ruling dynasty. It is this wedding that serves as the occasion for the performance of the play about the martyrdom of Adrian that is the impetus for Genest's revelation. Nonetheless, Rotrou does relate to the background history developed in Lope, when in the first scene Valérie shares her dream with Camille, as well as her concern about her father's capriciousness and irascibleness in possibly marrying her to someone below her, she alludes to the prophecy, which in Lope's play is made by Camila, that Dioclétian's power as emperor, and his marriage, were 'a reward for some bread he had received as a soldier': "Sut-il considérer, pour son propre hyménée, / Sous quel joug il baissait sa tête couronnée, / Quand, empereur, il fit sa couche et son État / Le prix de quelques pains, qu’il emprunta soldat, / Et par une faiblesse, à nulle autre seconde, / S'associa ma mère à l'Empire du monde?" (1.1, vv. 25-30; my italics). She also criticizes Dioclétian's subsequent division of power, first with Maximian (Maximiano in Lope) (“[...] on vît sur l'univers deux têtes souveraines, / [...] Maximian en partageât les rênes” 1.5, vv. 33 f.), and then through the tetrarchic system. ${ }^{698}$ Camille, defending Dioclétian, also refers to his rise to power and his low birth ("choisi par les siens" v. 58). ${ }^{699}$ It is interesting to

697 Note that in the first prints of the drama there is no reference to the scene of the action (cf. [Jean de Rotrou], Le veritable St Genest, tragedie de Mr de Rotrou, Paris 1648, s. p. ["Acteurs"]). As Diocletian's seat of government was in Nicomedia, the editors of the edition used here also set Nicomedia as the scene of the action (cf. p. 37: "[La scène est à Nicomédie.]"), others, however, refer to Rome, e.g., Crane (cf. Jean Rotrou's Saint Genest and Vencelas [cf. note 672], p. 140). According to the legend, the martyrdom of Genesius took place in Rome, and the martyrdom of Adrianus, treated in the inner play, occurred in Nicomedia. When Genest indicates to Maximin the 'realistic' representation of the event, he says that he will not be able to distinguish whether he sees the actual event in Nicomedia or only its representation in a play: '[...] [L]a mort d'Adrian [...] / [...] / Vous sera figurée avec un art extrême, / Et si peu différent de la vérité meme / [...] / [...] que vous douterez si dans Nicomédie / Vous verrez l'effet même, ou bien la comédie' (1.5, vv. 299-306).

698 "VALÉRIE: Depuis, Rome souffrit, et ne réprouva pas / Qu'il commit un Alcide, au fardeau d'un Atlas, / Qu'on vit sur l'univers deux têtes souveraines, / Et que Maximian en partageât les rênes. / Mais pourquoi pour un seul tant de maîtres divers, / Et pourquoi quatre chefs au corps de l'univers? / Le choix de Maximin, et celui de Constance / Étaient-ils à l'État de si grande importance, / Qu'il en dut recevoir beaucoup de fermeté, / Et ne put subsister sans leur autorité?” (1.1, vv. 31-40; cf. as well subsequently vv. 41-46).

699 The fact that he had married Valérie's mother (the character of Camila in Lope's play; Diocletian's wife and Valeria's mother was called Prisca), a peasant woman, did not harm his own position nor the rank of emperor, that he had been able to harmonize honor and love; 
note that in addressing the imperial characters' lower social origins (Maximin was an ordinary shepherd and Dioclétian a plain soldier) and emphasizing how their glorious and virtuous acts led to their achievement of a high rank, ${ }^{700}$ could also be read, in view of the conventions of tragedy that were becoming firmly established at the time when the play was written, as a way of justifying the protagonist Genest, since as an actor he is certainly from a lower social class.

Rotrou adopts Lope's use of the play, featuring an inner-fictional theater performance and a famous actor as protagonist, for the purpose of integrating contemporary references to drama and theories of performance. The corresponding scenes shall be briefly reviewed. Genest discusses different types of plays with Dioclétian (1.5), explaining that there are different types of theater, differentiating between plays that glorify the deeds of rulers ("[. . .] des tableaux parlants de vos rares exploits” 1.5, v. 216), and those that simply provide pleasure, entertainment, and distraction (“[. . .] à vos plaisirs” v. 212; "Mais quelque effort au moins par qui nous puissions dire / Vous avoir délassés du grand faix de l'Empire / Et, par ce que notre art aura de plus charmant, / Avoir à vos grands soins ravi quelque moment” 1.5, vv. 221-224). ${ }^{701}$ Dioclétian then

and even if he had co-rulers, he still remained "le plus solid appui" and the 'pilot' of the 'ship of state'; and that a deceptive dream image had made her misinterpret her father's actions (“CAMILLE: Vous prenez trop l'alarme, et ce raisonnement / N'est point à votre crainte, un juste fondement. / Quand Dioclétian éleva votre mère / Au degré le plus haut que l'univers révère, / Son rang qu'il partageait n'en devint pas plus bas, / Et lui faisant monter, il n'en descendit pas; / Il put concilier son honneur et sa flamme, / Et, choisi par les siens, se choisir une femme; / Quelques associés qui règnent avecque lui, / Il est de ses États le plus solide appui: / S'ils sont les matelots de cette grande flotte, / Il en tient le timon, il en est le pilote, / Et ne les associe à des emplois si hauts / Que pour voir des césars au rang de ses vassaux. / Voyez comme un fantôme, un songe, une chimère, / Vous fait mal expliquer les mouvements d'un père, / Et qu'un trouble importun vous naît mal à propos / D'où doit si justement naître votre repos” 1.1, vv. 51-68).

700 Cf. for instance Dioclétian to Maximin “[. . . pour faire vos prix égaux à vos mérites” (1.3, v. 121), "Puisse par cet hymen votre couche féconde / Jusques aux derniers temps donner des rois au monde, / Et par leurs actions ces surgeons glorieux / Mériter comme vous un rang entre les dieux! / En ce commun bonheur l'allégresse commune / Marque votre vertu plus que votre fortune [...]" (5.5, vv. 1627-1632).

701 Genest's intention is the latter, the reason he gives being the lack of adequate poetic models: "Permet de partager l'allégresse commune, / Et de contribuer en ces communs désirs, / Sinon à votre gloire, au moins à vos plaisirs, / [ . . ] / [ . .] que mes compagnons, vous offrent par ma voix, / Non des tableaux parlants de vos rares exploits, / Non cette si célèbre et si fameuse histoire, / Que vos heureux succès laissent à la mémoire / (Puisque le peuple grec, non plus que le romain / N'a point pour les [tracer] une assez docte main.) / Mais quelque effort au moins, par qui nous puissions dire / Vous avoir délassés du grand faix de l’Empire, / Et, par ce que notre art aura de plus charmant, / Avoir à vos grands soins ravi quelque moment” (1.5, vv. 
confirms that the theater is capable of realizing its intention to entertain, when he states that comedy can effect spectators' emotions so that the passion of tristesse becomes joie: 'Le comique, en ton art également succède, / Est contre la tristesse un si présent remède, / Qu'un seul mot, quand tu veux, un pas, une action, / Ne laisse plus de prise à cette passion, / Et par une soudaine, et sensitiv merveille, / Jette la joie au cœur, par l'œil ou par l'oreille' (1.5, vv.245-250). The decisive factor is the 'perfect illusion,' the creation of a 'pseudo-reality,' which the actor achieves by perfecting his art of feinte (pretense, deception). Thus, he goes beyond imitation to resurrect the characters he portrays. Moreover, the spectator, whether he wants to or not, and often to his own amazement, is 'carried away' by the emotions generated by the actor, which is how Dioclétian describes the effect that Genest's acting has had on him so far:



When the question of contemporary authors and plays is raised, Genest refers to the concept of taste. He prefers the Ancients, namely the works by Plautus and Terence ${ }^{703}$ and the "doctes Grecs" (1.5, v. 267). A few lines later - a point repeatedly noted by scholars - Genest praises Corneille (1606-1684) as an author of great tragedies on historical subjects. ${ }^{704}$ For Dioclétian, on the other

210-224). But the fact that Maximin is both spectator and character of the performed play, also guarantees the first aspect, as his 'fame as a persecutor of Christians' is presented theatrically. 702 On this 'conversation on theater,' cf. Bürger, "Illusion und Wirklichkeit” (cf. note 669), pp. 249 ff., here p. 250.

703 Lope's Ginés, too, in the corresponding passage refers to the famous Roman comedy poets.

704 There are allusions to Corneille’s Cinna (1643) and La Mort de Pompée (1644): “Genest: Nos plus nouveaux sujets, les plus dignes de Rome, / Et les plus grands efforts des veilles d'un grand homme / À qui les rares fruits que la muse produit / Ont acquis dans la scène un légitime bruit / Et de qui certes l'art, comme l'estime est juste, / Portent les noms fameux de 
hand, favors the new and surprising, since in his view this best fulfills the audience's expectation of being entertained. ${ }^{705}$ Before the performance begins (2.6), the inner audience praises the genre of tragedy. It suits Valérie's 'taste' ("Mon goût [...] est pour la tragédie;” 2.6, v. 453), and they particularly mention sublime subjects, brave actions, noble and influential ideas, the exemplary nature of kingly heroes, and representations of exemplary control and tempering of the passions. They also note that contemporary theater, in terms of equipment, art, and possibility, was ideally suited for this genre ("Le théâtre aujourd'hui, superbe en sa structure, / Admirable en son art, et riche en sa peinture, / Promet pour le sujet, de mêmes qualités” 2.6, vv. 461 ff.). Nevertheless, what was crucial for a great performance was good acting: "MAX.: Les effet en sont beaux, s'ils sont bien imités” (2.6, v. 464).

The beginning of the second act, the first scene of the play that takes place 'in the theater,' is quite remarkable for its explicit exposure of the artificial nature of theatrical illusion. This conveys a transparency that does not exist in Lo fingido verdadero. Genest gives the set designer last instructions for the scenery, emphasizing the need for splendor and appropriate illumination to achieve the effect of naturalness ("Il est beau; mais encor, avec peu de dépense, / Vous pouviez ajouter à sa magnificence, / N'y laisser rien d'aveugle, y mettre plus de jour, / [...] / Et surtout, en la toile où vous peignez vos cieux / Faire un jour naturel, au jugement des yeux;" 2.1, vv. 313-324; my italics). The designer refers to the effect of distance on perception, saying that from the audience's perspective, which is at a distance from the stage, the desired effect of the set stage scenery would come into its own. ${ }^{706}$

Pompée et d'Auguste. / Ces poèmes sans prix, où son illustre main / D'un pinceau sans pareil a peint l'esprit romain, / Rendront de leurs beautés votre oreille idolâtre, / Et sont aujourd'hui l'âme et l'amour du théâtre" (1.5, vv. 277-286).

705 “DiocL.: Je sais qu'en leurs écrits, l'art et l'invention / Sans doute, ont mis la scène en sa perfection; / Mais ce que l'on a vu n'a plus la douce amorce / Ni le vif aiguillon, dont la nouveauté force; / Et ce qui surprendra nos esprit et nos yeux, / Quoique moins achevé, nous divertira mieux" (1.5, vv. 271-276). One could argue that in Le Véritable Saint Genest, Rotrou tries to bring these two poles together, so to speak; the aspect of the 'twist that surprises' the audience manifests itself most strikingly in Genest's 'sudden' conversion, while at the same time the 'norms in terms of form' are respected.

706 "LE DÉCORATEUR: Joint qu'on voit mieux de loin ces raccourcissements, / Ces corps sortant du plan de ces refondrements; / L'approche à ces desseins ôte leurs perspectives, / En confond les faux jours, rend leurs couleurs moins vives, / Et comme à la nature, est nuisible à notre art / À qui l'éloignement semble apporter du fard. / La grâce une autre fois y sera plus entière" (2.1, vv. 327-332). Peter Bürger points to the usage of 'verbs of making/manufacturing' ("Verben des Herstellens") (peindre, faire, etc.), 'in the sense of the previously developed theory of perfect deception, the required naturalness is at the same time being denounced as fabrication.' 'The 
In Lope's drama, the blurring of the boundary between seeming and being, theatrical internal fiction and internal reality, character and actor, is highly elaborated on. This is particularly clear in the second act, which provides thematic coherence. The love plot, the intertwining of inner-fictional and play-internal levels of reality, the development and end of the first play within the play, make the action and the central event of the third act, Ginés' actual conversion and martyrdom, plausible. The second act, which shows the fallacy of earthly-erotic love, pre-figures, so to speak, the third act dedicated to Christian love. Just as Rotrou did not adopt the first act's action from his Spanish model, he also did not adopt the events of the second act. In Le Véritable Saint Genest there is no comparable complicated network of love relationships (between Ginés/Rufino-Marcela/FabiaOctavio/Octavio) permeating the boundaries of reality and illusion. The only play that is performed is about the Christian martyr Adrian; Genest, Marcelle, and Octave are not in the midst of a love-triangle; and love in general is not an issue for Rotrou's Genesius. Furthermore, Ginés not only acts in the plays he performs with his troupe, but he is also their author, who uses the events of his own life as fodder for the fiction, particularly in the comedia de amor. His 'acting theory' already manifests the instability of the border between play and reality, between impersonated figure and impersonator. In the second inner play, 'el cristiano bautizado,' Ginés essentially plays himself: an actor who plays a heathen who converts to Christianity. Whereas in Rotrou, the distinction between (intrafictional) play and (intra-fictional) reality is marked by a significantly higher degree of transparency. The actor Genest plays a character called Adrian; but what is not made clear or even mentioned is who the author of the play Le martyre d'Adrian is. The fact that the distance between actor and role, and the separation between fiction and reality is stronger in Rotrou than in Lope, can also be seen on the level of the secondary text. According to the stage directions to the first scenes of the second act, Genest dresses for the role of Adrian and is holding his script for a final rehearsal. ${ }^{707}$ Unlike Ginés, Genest does not improvise but refers

theater, on which the martyr's play is subsequently performed, arises before the spectators' eyes as an illusory world, a product of skilled craftsmen. As such speaks the décorateur when he points to the distance as an illusion-creating factor' (“[...] im Sinne der vorher entwickelten Theorie der vollkommenen Täuschung [...] [wird die] geforderte Natürlichkeit [zugleich] als Fabrikation denunziert”: "Das Theater, auf dem nachher das Märtyrerstück gespielt wird, entsteht vor den Augen des Zuschauers als eine Scheinwelt, Werk geschickter Handwerker. Als solcher spricht der Dekorateur, wenn er auf den Abstand als Illusion schaffendes Moment hinweist" [Bürger, "Illusion und Wirklichkeit” (cf. note 669), p. 252]).

707 Cf. at the beginning of 2.1: "Genest, s'habillant, et tenant son rôle [. . .]."; 2.2: "GENEST seul, se promenant, et lisant son rôle, dit comme en repassant et achevant de s'habiller."; 2.4: "GENEST seul, repassant son rôle, et se promenant." Note that these stage directions, as well as 
to a specific, pre-set script that he reads from while preparing for the performance. When, during the rehearsal scene, the border between actor and character is disrupted for the first time, the border between fiction and reality blurs, and Genest has the impression that he himself accepts the 'sentiments chrétiens' (2.4, v. 404): "Et puis, ayant un peu rêvé et ne regardant plus son rôle, il dit[:]" (my italics). Furthermore, the stage directions during the inner play provide clear information about who is speaking, the actor or the character. ${ }^{708}$ That Genest, unlike Ginés who emphasized the need for an actor to draw upon his own experiences when acting, generally maintains a distance from the characters he portrays, becomes clear when, while rehearsing, he becomes confused that it was he Genest who was experiencing the sense of Christian grace and not he as Adrian ('[...] que Christ me propose une gloire éternelle / Contre qui ma défense est vaine et criminelle;' 2.4, vv. 409 f.]), and he finally stresses: 'Il s'agit d'imiter, et non de devenir' (2.4, v. 420).

While in Lope the boundaries between appearance and being, illusion and reality are constantly destabilized, Rotrou's play does not imply any fundamental doubt about the ontological boundary between fiction (stage play) and reality. Although moments of uncertainty do exist, these misunderstandings, or the false attribution of phenomena to one pole or the other, are only temporary. The spectators are always able, through their reasoning, to recognize what is fiction and what (fictional) reality. This is much more problematized in Lo fingido verdadero, where it is difficult to rationally identify the difference between play and seriousness. The 'belief in the right thing' leading to 'right action,' the 'good performance of the right role' function here as guidelines that give security in a world that is perceived as inscrutable. Thus, while Lope, as has been noted, suggests a (Christian) dogmatic answer to skepticism's thesis of the unreliability of sensory perception (which is made explicit in the play itself) and of the ultimately impossible distinction between illusion and reality, Rotrou's drama offers a more rational approach. Rotrou's solution can be understood as part of a tradition of dealing with Pyrrhonian skepticism that seeks to overcome

those mentioned in the following note, and generally all used in this analysis of the play, are not additions of modern editing, they have been present since the first printed editions of Rotrou's drama (cf. for the ones referred to here: Le veritable St Genest, tragedie de Mr de Rotrou, Paris 1648, p. 19, p. 20, p. 24).

708 For example, when the play in the play starts in 2.7, the first direction reads: "GENEST, sous le nom d'ADRIAN," then the role name "Adrian" is always given until Genest returns to the stage after his 'real' baptism behind the stage: then his speeches are again indicated with "Genest"; the same applies to Marcelle/Natalie. Thus the directions allow the readers and producers of the play to clearly distinguish between fiction and reality in the play, but this does not necessarily carry over to the inner audience and the external viewers. 
skeptical doubt by creating a system of philosophical certainty, namely, Cartesian rationalism.

Particularly striking in Rotrou's play is the long 'play within the play,' which takes place from the seventh scene of the second act to the seventh scene of the fourth act. It is a theatrical fictionalization of a reality linked to the play's framing plot. Maximin plays an important function here, because he is, as he himself says, both spectateur and acteur of the action (cf. 1.5, vv. $307 \mathrm{f}$.) - as the officer who ordered Adrian to be executed, he is both the initial actor (instigator) of events and then the spectator of the action being portrayed, an action that then becomes once again real with the execution of Genest. The mirroring nature of Rotrou's 'play within the play' is thus, in comparison to Lope's inner plays, extended by a doubling, of the spectator. ${ }^{709}$ Maximin moreover represents the obligatory (enraged) ruler persecuting Christians, before whom Adrian affirms his commitment to Christianity and accepts his fate (cf. 3.2). Together with Dioclétian, Maximin also fills the role of imperial pagan antagonist, when the 'play has become serious,' after Genest professes his Christian beliefs, no longer in his stage role as Adrian, but as himself. The inner play's plot anticipates the remaining framing play. The doubling of the Christian martyrs Adrian and Genest in the inner play and the framing plot and the relevance of the character of Adrian for Genest's conversion will be discussed at a later point.

First, however, let us examine the aforementioned aspect of the temporary confusion between appearance and being. This is not only evident with regard to the distinction between the levels of theatrical internal fiction and internal reality, but is also present within the inner play itself. When Adrian receives Flavie's permission to visit his wife Natalie one last time, and comes to her alone, unguarded and without shackles, she immediately interprets her husband's appearance as a cowardly recantation. Her first words to him are: “[. . ] Comment, seul, et sans fers? / Est-ce là ce martyr, ce vainqueur des enfers? / Dont l'illustre courage et la force infinie, / De ses persécuteurs, bravaient la tyrannie?” 4.4, vv. 1101-1104). She then brusquely turns him away, and launches into a long angry speech in which she deplores his betrayal of her and God she herself would be willing to take torture and death for her faith - and his weakness and cowardice (cf. 4.4, vv. 1105-1147). When Adrian after several attempts eventually gets a chance to speak, he successfully clears up the misunderstanding ('Je te vais détromper;' v. 1140) by explaining her that he only

709 Note that as a consequence, in the context of the theatrum mundi-concept, this implies for the external spectators that their own earthly existence is a fiction and a role in the Godgoverned world (cf. Forestier, Le théâtre dans le théâtre sur la scène française du XVII siècle [cf. note 3], pp. 300 f.). 
wanted to say goodbye to her, that God reigned in his heart and nothing could shake his faith, that he was going "armé d'un invincible zèle” (4.4, v. 1151) towards what was ahead of him (cf. 4.4, vv. 1147-1166). Natalie is immediately convinced. She does not have any further doubt about the sincerity of his words. Within the 'play within the play' the character of Natalie is often shown as being feinte, deceptive. She reveals to Adrian that she herself is a Christian and has been living a life of deception by hiding her faith and practicing in secret (cf. 3.5, vv. 868-906). ${ }^{710}$ Later, after leaving her husband she encounters Flavie and deceives him by saying that she has tried hard but unsuccessfully to persuade her husband to recant (cf. 3.6, vv. 959-974).

Regarding the modification in the depiction of the conversion, it is interesting to compare the scenes of the rehearsal and that of baptism during the course of the 'play within the play' in the two dramas. When Ginés asks for baptism as he prepares for the role of the Christian, music sounds, the 'heavens open' and the spectators/readers are treated to an impressive spectacle of Mary, Jesus, and God the Father on the heavenly throne, surrounded by martyrs. In Rotrou, the metaphysical dimension is only alluded to by: 'Le ciel s'ouvre avec des flammes [...].' Only the empyrean is visible. This can perhaps be seens as reflecting a more rationalistic attitude towards religion. As has already been shown, also the doubt about the status of the voice that Genest subsequently hears is developed in a far less complex way (for both the characters and the audience/readers) than in Lope's play, and is confined to a (brief) argumentative engagement by Genest. When during the 'play within the play' Genest, as Adrian, asks Anthyme, played by Lentule, to baptize him, ${ }^{711}$ and the latter reminds him that the upcoming 'blood baptism' is more than sufficient for his salvation, Genest breaks character and explicitly states: 'Ce n'est plus Adrian, c'est Genest qui respire / La grâce du baptême et l'honneur du martyre;' (4.5, vv. 1247 f.). By clearly differentiating the figure of Adrian from the actor Genest, the play explicitly turns from fiction to reality, play to seriousness, a transparent shift that did not take place at any point in Lope. When Genest/ Adrian then looks up to heaven and sees the flames bursting forth, he speaks about an angel calling him to baptize him, and goes backstage. The actors explain the incident by interpreting it as an improvisation on Genest part because he possibly forgot his lines. The spectators, on the other hand, understand what happened as an impressive moment of theater/performance. The 'miracle

710 Worshipping the pagan gods only 'in pretense' is an argument that Marcelle (who plays Natalie) makes when she tries to persuade Genest to recant in order to save his life and the actors' jobs (cf. 5.2, 1581-1586).

711 For this scene, see above p. 262. 
of baptism' takes place behind the scenes. Genest then returns to the stage and in a speech replete with acting metaphors, he addresses God, praises the power of baptism and places himself at the service of his new faith. ${ }^{712}$ Without being aware of the truth of their assessment, the inner spectators classify this as a '[.. .] feinte [qui] passerait pour la vérité même' (4.7, v. 1284). In Lope's play, however, an angel appears on stage, calling Ginés to him so that he can baptize him. Ginés goes to the angel and the baptism takes place on stage (more precisely, above the stage). The scene is accompanied by stirring music and angels holding baptismal utensils are visible. Although in Rotrou the miracle of the conversion and baptism is represented much less dramatically than in Lope, the abrupt nature of the change, the sudden turning from pagan actor playing a Christian to a real Christian, is much clearer. In Lope's drama, the authenticity of the baptism, the understanding of what is perceived as a miracle, is ultimately only possible in retrospect, when the actor playing the angel in the 'play within the play' appears on stage to perform his role of baptizing Ginés for what the inner spectators see as the second time; the border between illusion and reality remains unstable. A significant difference with regard to the emphasis on conversion and martyrdom is already indicated by the words Genest hears in the rehearsal scene: 'UnE VoIx: Poursuis Genest ton personnage, / Tu n'imiteras point en vain; / Ton salut ne dépend, que d'un peu de courage, / Et Dieu t'y prêtera la main' (2.4, vv. 421-424; my italics). The promise of the soul's salvation for a good performance, more precisely for following, and emulating the character he is portraying, is reinforced by the aspect of the necessary courage, the zeal. After his 'real' conversion Genest professes himself a Christian before the emperors, and metaphorically places this conversion in the context of the theatrum mundi, just as Ginés does, saying the 'play has become truth. ${ }^{713}$ In addition, in Le Véritable Saint Genest, the aspect of the

712 'Suprême Majesté, qui jettes dans les âmes / Avec deux gouttes d'eau, de si sensibles flammes, / Achève tes bontés, représente avec moi / Les saints progrès des coeurs convertis à ta foi! / Faisons voir dans l'amour, dont le feu nous consomme, / Toi le pouvoir d'un dieu, moi le devoir d'un homme; / Toi l'accueil d'un vainqueur, sensible au repentir, / Et moi, Seigneur, la force et l'ardeur d'un martyr' (4.7, vv. 1275-1282; my italics).

713 Cf. "Dedans cette action, où le Ciel s'intéresse / Un ange tient la pièce, un ange me redresse; / Un ange par son ordre, a comblé mes souhaits, / Et de l'eau du baptême, effacé mes forfaits; / Ce monde périssable, et sa gloire frivole / Est une comédie où j’ignorais mon rôle; / J'ignorais de quel feu mon cœur devait brûler / Le démon me dictait, quand Dieu voulait parler; / Mais depuis que le soin d'un esprit angélique / Me conduit, me redresse, et m'apprend ma réplique, / J'ai corrigé mon rôle, et le démon confus, / M'en voyant mieux instruit, ne me suggère plus; / J'ai pleuré mes péchés, le Ciel a vu mes larmes, / Dedans cette action, il a trouvé des charmes, / M’a départi sa grâce, est mon approbateur, / Me propose des prix, 
exemplary nature of the heroic martyr is of importance. ${ }^{714}$ Through the miracle of his conversion Genest is able to follow in the footsteps of Adrian, the revered Christian martyr. The first words that Genest speaks as Adrian are particularly notable: "Ne délibère plus, Adrian, il est temps / De suivre avec ardeur ces fameux combattants; / Si la gloire te plaît, l'occasion est belle; / La querelle du Ciel à ce combat t'appelle; / La torture, le fer, et la flamme t'attend; / Offre à leurs cruautés un cœur ferme et constant;" (2.2, vv. 335-340). ${ }^{715}$ Adrian wants to follow the example of courageous Christians who bravely endured their martyrdom like warriors. Adrian's conversion and willingness to die a martyr's death have a different motivation from that of Genest, as we learn from 'his' reflection on his experience and divine grace that led to his conversion and his conviction of faith. ${ }^{716}$ He also remarks, after Natalie has told him that she, too, is a Christian: "Enfin, je reconnais, ma chère Natalie, / Que je dois mon salut au

et m'a fait son acteur" (4.7, vv. 1298-1314; my italics); 'Ce n'est plus Adrian, c'est Genest qui s'exprime; / Ce jeu n'est plus un jeu, mais une vérité, / Où par mon action je suis représenté, / Où moi-même l'objet et l'acteur de moi-même, / Purgé de mes forfaits par l'eau du saint baptême, / Qu'une céleste main m'a daigné conférer, / Je professe une loi, que je dois déclarer' (4.7, vv. 1324-1330); 'J’ai souhaité longtemps d'agréer à vos yeux, / Aujourd'hui je veux plaire à l'Empereur des cieux; / Je vous ai divertis, j’ai chanté vos louanges; / Il est temps maintenant de réjouir les anges, / Il est temps de prétendre à des prix immortels, / Il est temps de passer du théâtre aux autels; / Si je l'ai mérité, qu'on me mène au martyre; / Mon rôle est achevé, je n'ai plus rien à dire' (4.7, vv. 1365-1372).

714 In addition to the constant emphasis on the aspects courage, constance, and vertu, this emphasis becomes apparent as well in the inner play, where Natalie, too, mentions numerous martyrs whose example she wants to follow one day (cf. 3.7, vv. 1017-1022). After his conversion, Genest qualifies martyrdom as the fulfillment of a human ('heroic') duty ('le devoir d'un homme'; cf. 4.7, vv. 1279-1282).

715 These are also the first line of the inner play (2.7, vv. 477-482).

716 Cf. from the opening monologue: “GENEST sous le nom d'ADRIAN: J'ai vu, ciel, tu le sais, par le nombre des âmes / Que j'osai t'envoyer, par des chemins de flammes, / Dessus les grils ardents, et dedans les taureaux, / Chanter les condamnés, et trembler les bourreaux; / J'ai vu tendre aux enfants une gorge assurée, / À la sanglante mort qu'ils voyaient préparée; / Et tomber sous le coup d'un trépas glorieux, / Ces fruits à peine éclos, déjà mûrs pour les cieux. / J'en ai vu, que le temps prescrit par la nature, / Était prêt de pousser dedans la sépulture, / Dessus les échafauds presser ce dernier pas, / Et d'un jeune courage, affronter le trépas; / J'ai $v u$ mille beautés, en la fleur de leur âge, / À qui jusqu'aux tyrans, chacun rendait hommage, / Voir avecque plaisir, meurtris et déchirés, / Leurs membres précieux, de tant d'yeux adorés; / Vous l'avez vu, mes yeux, et vous craindriez sans honte, / Ce que tout sexe brave, et que tout âge affronte! / Cette vigueur, peut-être, est un effort humain? / Non, non, cette vertu, Seigneur, vient de ta main, / L'âme la puise au lieu de sa propre origine, / Et comme les effets, la source en est divine. / C'est du ciel que me vient cette noble vigueur, / Qui me fait des tourments mépriser la rigueur, / Qui me fait défier les puissances humaines;” (2.7, vv. 495-519; my italics). 
saint nœud qui nous lie;" (3.5, vv. 907 f.). Furthermore, in the course of vindicating his faith before Flavie-and this is all the more contrary to the nature of Genest's conversion-he declares: "La grâce dont le ciel a touché mes esprits, / M’a bien persuadé, mais ne m’a point surpris;” (2.9, vv. 645 f.).

In contrast to Lope's comedia, Rotrou's drama is much more discursive (raisonnement), with the characters reflecting on and explicitly (and extensively) defending Christianity, in both the inner play and the framing plot (cf. the prison scenes in the Act 5). There is also a great deal of proselytizing, an aspect that is entirely absent in Lope. Even though Genest has no followers and there is no further conversion to Christianity in Le Véritable Genest ${ }^{717}$ the issue is nevertheless present. Genest attempts, for example, to persuade his fellow actors 'to save their souls,' (during the 'play within the play,' immediately after his baptism [cf. 4.7, vv. 1287-1295]), and again in the long discussion with Marcelle and his refusal to recant (cf. 5.2, vv. 1541-1546). It is also expressed by Dioclétian, who describes the persecution of Christians as counter-productive and ultimately damaging due to the contagious character and increasing numbers of conversions and martyrdoms in his empire: "J'en vois du sang d'un seul naître des légions. / [...] / Un ennemi défait leur en reproduit mille; / Et le caprice est tel de ces extravagants / Que la mort les anime et les rend arrogants" (5.5, vv. 1650-1654).

In Lope's comedia, Ginés uses theatrical imagery in his final speech, in which he once again explicitly discusses his conversion and approaching martyrdom, as well as the emptiness of this world and the reward awaiting him in the hereafter. Genest also uses theatrical imagery, speaking of how the world was a stage on which he played a 'false role' until his conversion (cf. 'Ce monde périssable et sa gloire frivole / Es tune comédie où j'ignorais mon rôle;' 4.7, vv. 1303 f.). ${ }^{718}$ Remarkably it is the other (pagan) characters who metaphorically place his 'real' martyr's death that follows upon his confession, within the context of a play (thus also situating it within the realm of fiction, implying a continuation of the aborted 'play within the play'). When the jailer takes him away after the discussion with Marcelle, he remarks: 'Si bientôt à

717 In contrast to Desfontaines' drama, as we will see below.

718 Cf. as well in a distinctive form: 'J'ai souhaité longtemps d'agréer à vos yeux, / Aujourd'hui je veux plaire à l'Empereur des cieux; / [. . . / Il est temps de passer du théâtre aux autels;' (4.7, vv. 1365-1370). Moreover: 'Mais depuis que le soin d'un esprit angélique / Me conduit, me redresse, et m'apprend ma réplique, / J’ai corrigé mon rôle, et le démon confus, / M’en voyant mieux instruit, ne me suggère plus; / J'ai pleuré mes péchés, le ciel a vu mes larmes, / Dedans cette action, il a trouvé des charmes, / M’a départi sa grâce, est mon approbateur, / Me propose des prix, et m'a fait son acteur' (4.7, vv. 1307-1314). 
nos dieux vous ne rendez hommage, / Vous vous acquittez mal de votre personnage; / Et je crains en cet acte un tragique succès' (5.4, vv. 1619-1621), to which Genest himself, and these are his last lines in the play, replies using metaphors from the field of law, evoking the image of Divine Judgment: 'Un favorable juge assiste à mon procès; / Sur ses soins éternels, mon esprit se repose; / Je m’assure sur lui du succès de ma cause; / De mes chaînes par lui je serai déchargé, / Et par lui-même un jour, César sera jugé' (5.4, vv. 1622-1626). Maximin describes the execution of Genest as a 'bloody spectacle' (spectacle sanglant) enacted before the people, because: 'Si déjà sur le bois d'un théâtre funeste / Il n'a représenté l'action qui lui reste' (5.5, vv. 1666 ff.). Plancien expresses the notion of Genest's execution as the 'last act of a tragedy' and compares (from a non-Christian perspective and consequently reaching contrary conclusions to those that Genest reached earlier in the play) Genest's life with a stage play; as an actor on the Roman stage Genest had glamorously and gloriously imitated famous heroes, while in the play of his own story (his real life) did the opposite. ${ }^{719}$ Nevertheless, Genest's performance in this 'acte sanglant' has a profoundly moving impact on the spectators. ${ }^{720}$ It is interesting that this sense of Genest as a hero and his fate as a tragedy, is undermined by Maximin, who in his speech that concludes the play, refers to Genest's fate as selfinflicted and therefore not to be lamented, saying further that Genest had had the power to avert his own death, but because of his 'impiety' deliberately chose to turn the play into reality ('Ne plaignez point, Madame, un malheur volontaire, / Puisqu'il l'a pu franchir, et s'être salutaire; / Et qu'il a bien voulu, par son impiété, / D’une feinte, en mourant, faire une vérité' 5.7, vv.1747-1750; my italics). From Genest's Christian perspective, physical death, however cruel, is only a passage to the glory of eternal life and thus is met with happiness. What is decisive is divine grace - an aspect that dominates both the inner play and the framing plot - particularly the acceptance of divine grace. This concept of acceptance is closely tied to what, in Maximin's words, becomes a negative, the aspect of choice. Thus, in the course of his dialogue with

719 Cf.: 'Par votre ordre, Seigneur, ce glorieux acteur, / Des plus fameux héros, fameux imitateur, / Du théâtre romain, la splendeur et la gloire, / Mais si mauvais acteur dedans sa propre histoire, / Plus entier que jamais en son impiété, / Et par tous mes efforts en vain sollicité, / A du courroux des dieux, contre sa perfidie, / Par un acte sanglant, fermé la tragédie' (5.7, vv. 1717-1726).

720 Cf. as well here once again: 'Nous souffrions plus que lui, par l'horreur de sa peine; / Et nos cœurs détestant ses sentiments chrétiens, / Nos yeux ont malgré nous fait l'office des siens; / Voyant la force enfin comme l'adresse vaine, / J'ai mis la tragédie à sa dernière scène' (5.7, vv. 1736-1740). 
Marcelle, for instance, Genest notes: 'Ta grâce peut, Seigneur, détourner ce présage! / Mais hélas! Tous l'ayant, tous n'en ont pas l'usage; / De tant de conviés, bien peu suivent tes pas, / Et pour être appelés, tous ne répondent pas' (5.2, vv. 1575-1578). ${ }^{721}$ Genest's reflection on his conversion and imminent death, focusing on divine grace, can be found developed in extenso in his stanza-monologue at the beginning of the fifth act, quoted here below. These verses can be understood as a Christian answer to Maximin's remark:

\author{
Pour lui la mort est salutaire; \\ Et par cet acte de valeur \\ On fait un bonheur volontaire, \\ D’un inévitable malheur; \\ [...] \\ Mourrons donc, la cause y convie; \\ Il doit être doux de mourir \\ Quand se dépouiller de la vie \\ Est travailler, pour l'acquérir; \\ Puisque la célèbre lumière \\ Ne se trouve qu'en la quittant \\ Et qu'on ne vainc qu'en combattant; \\ D'une vigueur mâle et guerrière \\ Courons au bout de la carrière \\ Où la couronne nous attend. ${ }^{722}$
}

(5.1, vv. 1451-1470)

\footnotetext{
721 Cf., furthermore, the following words by Genest addressed to Marcelle: "Si d'un heureux avis, vos esprits sont capables, / Partagez ce forfait, rendez-vous en coupables, / Et vous reconnaitrez, s'il est un heur plus doux / Que la mort, qu'en effet je vous souhaite à tous. / Vous mourriez pour un Dieu, dont la bonté suprême, / Vous faisant en mourant détruire la mort même, / Ferait l'éternité, le prix de ce moment, / Que j'appelle une grâce, et vous un châtiment” (5.2, vv. 1487-1494).

722 "Par quelle divine aventure, / Sensible et sainte volupté, / Essai de la gloire future, / Incroyable félicité, / Par quelles bontés souveraines, / Pour confirmer nos saints propos, / Et nous conserver le repos / Sous le lourd fardeau de nos chaînes, / Descends-tu des célestes plaines, / Dedans l'horreur de nos cachots? // Ô fausse volupté du monde, / Vaine promesse d'un trompeur! / Ta bonace la plus profonde / N'est jamais sans quelque vapeur; / Et mon Dieu, dans la peine même / Qu'il veut que l'on souffre pour lui, / Quand il daigne être notre appui, / Et qu'il reconnaît que l'on l'aime, / Influe une douceur extrême / Sans mélange d'aucun ennui. // Pour lui la mort est salutaire, / Et par cet acte de valeur / On fait un bonheur volontaire / D'un inévitable malheur. / Nos jours n'ont pas une heure sûre, / Chaque instant use leur flambeau, / Chaque pas nous mène au tombeau. / Et l'art imitant la nature, / Bâtit d'une même figure / Notre bière, et notre berceau. // Mourrons donc, la cause y convie; / Il doit être doux de mourir / Quand se dépouiller de la vie / Est travailler, pour l'acquérir; / Puisque la célèbre lumière / Ne se trouve qu'en la quittant / Et qu'on ne vainc qu'en
} 
Rotrou refers to the tragic motif of man's subjection to fate on numerous occasions throughout the play. For instance, when Dioclétian says: "Les dieux, premiers auteurs des fortunes des hommes, / Qui dedans nos États, nous font ce que nous sommes; / Et dont le plus grand roi, n'est qu'un simple sujet [...]" (5.5, vv. 1635 ff.). ${ }^{723}$ This is also expressed by Valérie in the opening scene of the drama, in the context of her telling of her dream: "Mais me répondras-tu des caprices du sort? / Ce monarque insolent, à qui toute la terre / Et tous ses souverains, sont des jouets de verre” (1.1, vv. 72 ff.). ${ }^{724}$ Thus, Rotrou's drama begins with the problematization of seeming and being, illusion and reality, and the potential effectiveness of the supposedly illusionary on reality. This liminal confusion is not the purpose of the play, however. In fact, throughout the play the real persona (Genest) is clearly distinguished from his role (Adrian) so that the text always maintains a clear distinction between what is play and what is reality, and the point where the two are joined is precisely defined. ${ }^{725}$

combattant; / D'une vigueur mâle et guerrière / Courons au bout de la carrière / Où la couronne nous attend" (5.1, vv. 1431-1470).

723 In the inner play, Flavie notes similarly: "Les dieux, dont comme nous, les monarques dépendent” (2.8, v. 587), subsequently Adrian: “C'est le Dieu que je sers qui fait régner les rois, / Et qui fait que la terre en révère les lois” (2.8, vv. 589 f.). Furthermore, Genest’s reasoning during the rehearsal scene about seeing his soul as a battleground of divine powers, would allow for such an interpretation (cf. 'Prenez, dieux, contre Christ, prenez votre parti, / Dont ce rebelle cœur s'est presque départi; / Et toi, contre les dieux, ô Christ, prends ta défense, / Puisqu'à tes lois, ce cœur fait encor résistance; / Et dans l'onde agitée où flottent mes esprits, / Terminez votre guerre, et m'en faites le prix; / Rendez-moi le repos dont ce trouble me prive' 2.4, vv. 439-445).

724 This element does not exist in Lope's drama, where there is only a brief mention of a dream by Diocleciano, in which Numeriano's shadow had told him to avenge him and kill Apro. A comparable aspect, however, is Camila's prophecy, this is where burlas eventually become veras. In tragedies, dreams and their interpretation are common topics. This is the dream Valérie has: "Déjà cinq ou six nuits, à ma triste pensée / Ont de ce vil hymen la vision tracée, / M'ont fait voir un berger, avoir assez d'orgueil / Pour prétendre à mon lit, qui serait mon cercueil, / Et l'Empereur mon père, avec violence, / De ce présomptueux appuyer l'insolence" (1.1, vv. 13-18). See above pp. $254 \mathrm{f}$.

725 Rotrou's use of the story of the Genesius legend and his drawing on Lope's Spanish comedia to write a French tragédie in the 1640s must be understood in the context of dramatic production that had to grapple with the conventions of the doctrine classique. Following the 'Querelle du Cid' (1637), the tendency towards 'neo-classicistic' principles was consolidated. However, the relevant theoretical texts, such as La pratique du théâtre by the Abbé d'Aubignac in 1657 and Boileau's L'Art poétique only in 1674, appeared only years after Rotrou's drama. Nevertheless, as Peter Bürger states, 'since the beginning of the 1640s, in France, the rule of the dramatic norms was firmly established' ("[s]eit Beginn der vierziger Jahre des 17. Jahrhunderts [war] in Frankreich die Herrschaft der dramatischen Regeln fest etabliert” 


\subsection{Desfontaines, L'Illustre Comédien ou le Martyre de Saint Genest (1645)}

\section{The tragedy L'Illustre Comédien ou le Martyre de Saint Genest [The Illustrious} Actor or the Martyr of Saint Genesius] by Nicolas-Marc Desfontaines, first printed in 1645 and composed only a short time before Rotrou's Le Véritable Saint Genest, is a dramatization of the Genesius story that is little known outside of scholarly research. ${ }^{726}$ Given the subject matter of the drama, it is interesting to compare it to the two texts by Lope and Rotrou. ${ }^{727}$

Desfontaines' play has striking differences in terms of his characters. Apart from Diocletian, there are no other figures from Roman history. He dramatizes neither the complex issues surrounding Diocletian's rise to Roman Emperor (Lope), nor the political storyline that Rotrou develops (in so far as Diocletian's

["Illusion und Wirklichkeit” (cf. note 669), p. 243]). Note that Rotrou's drama is, of course, not intended to be presented here as a typical stage work of French classicism - in (older) scholarly research, Rotrou is always seen as a playwright of the 'Baroque' (in contrast to 'Classicism') -, but rather as a tendency in this direction that is clearly different from the Spanish theater of that period. Another aspect pertinent to the dramatization of a 'sacred subject matter' is the Church's more pronounced disavowal of theater in France than in Spain at that time. (As early as 1548 an edict of the Parisian parliament had forbidden the Confrérie de la Passion to perform religious plays.) A groundbreaking work in this context was Corneille's martyr-play Polyeucte martyr, first published in 1642 and performed with great success (in 'public' theater). In publications from 1682 onward the play was subtitled "tragédie chrétienne.” (In his drama-theoretical treatise Trois discours sur le poème dramatique [1660], Corneille explained his concept of tragédie chrétienne.) Even if no closer comparison between Corneille's Polyeucte and Rotrou's Saint Genest is made here, it is important to note that Rotrou presumably adopted many of Corneille's dramatic structures. Corneille's 'Christian tragedy' also begins thematically with a dream, while the prison scenes in the fifth act of Rotrou's play are very reminiscent of the first and second scenes of the fourth act in Corneille: There, the converted Polyeucte, waiting in prison for his execution, has a (prominent) stanzamonologue; in the following scene his wife Pauline comes to try and convince him to recant his new faith, but without success; Pauline also becomes a Christian, as does her father Félix, the Roman governor of Armenia, who had ordered Polyeucte's execution. (Used edition: Pierre Corneille, Polyeucte martyr: Tragédie chrétienne, in: Pierre Corneille, Théâtre complet, ed. Liliane Picciola, 2 vols., Paris 1993-1996, vol. 2 [1996], pp. 1-89). It is possible that Desfontaines' martyr's drama was also influenced by the success of Corneille's Polyeucte.

726 See, e.g., Christopher Semk, Playing the Martyr: Theatre and Theology in Early Modern France, Lewisburg 2017, who discusses Rotrou's and Desfontaines' Genesius plays in chapter 3 of his study, pp. 62-89 (“'Ex histrionis martyr factus': Genesius, Acting, and Martyrdom”).

727 References to the play are to the edition: Nicolas Mary Desfontaines, L'Illustre Comédien, ou Le Martyre de Sainct Genest: Tragédie, Paris 1645, and will be given parenthetically in the body of the text indicating act and scene numbers. 
elevation of Galerius [Maximin] to Caesar and his marriage to Valeria are the theme of the framing plot). ${ }^{728}$ In Desfontaines, Dioclétian is joined, on the one hand, by his confident Aquillin ("Favory de l'Empereur") and, on the other hand, by the state councilor Rutile (“Conseiller d'Estat de l'Empereur”). In addition to Genest, Aristide, Anthenor, Pamphilie, and Luciane form part of the famous actor's acting troupe. The play's action takes place, as in Rotrou, solely in Rome.

In the first scene, set in the imperial palace, Aquillin praises Dioclétian's absolute power, saying that only the gods were his rivals. While Jupiter was the ruler of heaven, he was the sole ruler on earth, the Persians were defeated, his opponent Carinus subjected. He had defeated all his enemies, except for some Christians, who, however, were attacking the gods but not his empire ("Horsmis quelques Chrestiens tu n'as plus d'ennemis, / Et cette secte impie alors qu'elle conspire, / Ne s'attaque qu'aux Dieux \& non à ton Empire” 1.1). Dioclétian contradicts Aquillin, saying that the Christians were indeed a threat to his empire and represented a great evil that must be fought. ${ }^{729}$ Rutile, while affirming that he despises Christians to the same extent as his lord does, seeks, however, to persuade Dioclétian to moderate the severe measures, i.e. torture and executions, he was using against Christians, for it was not through the body, but through the soul, through reason, that the problem needed to be addressed. ${ }^{730}$ He proposes that the Christians be persuaded to return to the worship of the Roman gods, through the persuasive power of the theater: the scaffolds should be turned into magnificent theater stages on which the faults and abuses of Christians could be mocked. The famous actor Genest, known for his ability to effect and convince people by means of his art, should be commissioned to put on such a performance in the palace in order to try out this option:

728 Which may also be an indication that Lo fingido verdadero was not one of Desfontaines' sources.

729 “DiOCLETIAN: Non, non, ce mal est grand dez qu'il commence à naistre / Il le faut estouffer pour l'empescher de croistre, / Et venger par l'effect de nos justes arrests / De la Terre \& des Cieux les communs interests" (1.1).

730 "RuTILE: Mais comme les erreurs de cette troupe infame / Sont enfin des deffaux qui s'attachent à l'ame, / Je treuve que l'on fait d'inutiles efforts / Pour guerir les esprits d'en affliger les corps, / Cette superieure \& plus noble partie / Par des effets si bas n'est point assujettie / Elle brave ses fers, \& rit de sa prison, / Pour suivre seulement les loix de la raison: / Elle seule la dompte, elle seule est sa Reine, / Et sur elle, elle seule agit en souveraine; / Pour ranger les Chrestiens aux termes du devoir / Une fois, ô Cesar, sers toy de son pouvoir: / Faits agir la raison, laisse agir les exemples, / Tasche par la douceur de les mener aux Temples, / Et sans plus les forcer, donne leur le loisir, / D'examiner un peu ce qu'ils doivent choisir” (1.1). 


\footnotetext{
Changer les eschaffauts en superbes Theatres,

Et là, leur faire voir dans la derision

L'erreur \& les abus de leur Religion,

Tu sçais combien, Genest, cet Illustre Comique

A de grace \& d'addresse en tout ce qu'il pratique,

Et qu'au gré de sa voix, \& de ses actions,

Il peut comme il luy plaist changer nos passions,

Esgayer nos esprits, les rendre solitaires,

Amoureux, mesprisans, pitoyables, coleres,

Et par un souverain \& merveilleux pouvoir

Imprimer en nos coeurs tout ce qu'il nous fait voir,

Commande luy, Seigneur, d'exposer sur la scene

Les superstitions d'une trouppe peu saine

Qui se nourrit d'espoir, \& pour de faux appas,

Quitte l'heur qui la suit \& qui luy tend les bras,

Si tu doutes encor des traits de ta science

Tu peux dans ton Palais en faire experience,

Et par un coup d'essay de cét art merveilleux

En toy-mesme esprouver ce qu'il pourra sur eux.
}

(1.1; my italics)

Dioclétian agrees to this suggestion. Genest's acting troupe, already waiting in the palace, is ordered to appear before him.

Thus, in Desfontaines, the framework for the 'play within the play' is a completely different one than in Lope or Rotrou. The occasion is not a festive event and the performance is not intended to contribute to the entertainment of the court. The drama's starting point is a consideration of how to address the 'Christian problem,' as the increasing number of Christians appears as a great threat to imperial power, the kindom's peace, and the gods' contentment. Theater is explicitly identified as an instrument of propaganda: rather than the bloody exercise of state power to counter the dangers posed by Christians, the (gentle) 'power of persuasion' of the theatrical performance is going to effect change by ridiculing Christianity on stage. Genest's acting, too, is explicitly put in this context. The imperial audience is to decide on the effectiveness of this approach. Thus, in Desfontaines' play, as S. Laemmel puts it, the audience of the 'play within the play' is 'not a celebration audience, but a test audience' ("kein Fest-, sondern ein Testpublikum"). ${ }^{731}$

When the actors come before the emperor (1.2), Genest at first suggests presenting Dioclétian's great deeds (his victories over the Persians and barbarians, etc.) on stage. Rutile, however, explains what kind of play Dioclétian wants to see, namely, ridiculing of the Christian faith and rites and ending in praise of

731 Laemmel, “Zur Adaptation einer 'comedia de santo' in Frankreich” (cf. note 494), p. 472. 
the Roman gods. ${ }^{732}$ Genest's answer reflects the play's adherence to the legend: Genest says that he is a declared enemy of Christians, who had fled the 'Christian environment' in his youth, ${ }^{733}$ an element that is also mentioned in Rotrou; he suggests enacting a mock (and mocking) baptism on stage. He states that there is hardly anything more amusing than the extreme fallaciousness of the 'miracle' the Christians call baptism and their belief that three drops of water were enough to elevate them to heaven. Genest further declares that he was ready to put on the entertainment the emperor wanted and the play would be so effective, and Christians portrayed in such a bad light, that they would be insane not to recant their new beliefs and concluding that shame often had more effect than pain. ${ }^{734}$

When the actors are alone (1.4), they discuss which play to perform that would best suit the emperor's wishes and win his favor. Apparently, the suggested subject matter was new to them. The actor Anthenor remarks: "Mais quelle Histoire enfin peut servir de sujet / Et propre \& convenable à ce rare projet?” (1.4; my italics). Unlike in Lope, and to a lesser extent in Rotrou, it is never suggested that Ginés/Genest is famous for his portrayal of Christians. Aristide, another actor in the group, proposes that they present the story of Ardalion or Porphyrius, popular men deceived into following Christians and ending up

732 "Rutile: Faites voir leurs abus, descouvrez leur erreur, / Rendez les des humains \& la honte, \& l'horreur, / Mocquez-vous de leur foy, riez de leurs mysteres, / Des superstitions de leurs regles austeres, / Et des appas trompeurs de tant d'illusions / Qui seduisent leurs sens \& leurs opinions. / Rendez-les en un mot de tout poinct ridicules: / Mais d'ailleurs exaltez Jupiter, nos Hercules, / Nos Mars, nos Apollons, \& tous les autres Dieux / Qu'ont icy de tout temps adoré nos ayeux. / Je ne vous puis donner de conseil plus utile” (1.3).

733 “GENEST: Ny prescrire d'employ qui nous soit plus facile, / Ces Rebelles, des Dieux \& des hommes hays, / M'ont fait abandonner mon Pere, \& mon Pays, / Où ne pouvant souffrir leurs coupables maximes / Je me suis par ma fuitte affranchy de leurs crimes / De sorte que contre eux justement animé, / Je feray voir l'abus dont ce peuple est charmé: / Et que le vain espoir qui le flatte \& le lie / N'est rien qu'une chimere, un songe, une folie, / Qui s'estans emparez de ces foibles esprits / Les rend de l'univers la fable \& le mespris” (1.3).

734 “GENEST: Est-il rien de plaisant comme l'erreur extreme / D'un mystere nouveau qu'ils appellent Baptéme, / Où de trois gouttes d'eau legerement lavez, / Ils se pensent desja dans les cieux eslevez? / Certes on ne peut trop admirer leurs manies / De croire que deux mots, \& des ceremonies / Puissent en un moment les rendre glorieux, / Au point que d'aspirer au partage des Cieux. / C'est par cette action si digne de risée, / Et des meilleurs esprits de tout temps mesprisée / Que je veux commencer les divertissemens, / Que l'Empereur attend de nos raisonnemens, / Nous ne sçaurions choisir de plus belle matiere. / C'est là que me donnant une libre cariere, / Je mettray les Chrestiens en un si mauvais point / Qu'ils seront insensez s'ils ne se changent point. / Ces moyens, quoy que doux, peuvent plus que les gesnes, / Et la honte souvent fait bien plus que les peines" (1.3). 
disgraced. Luciane adds that both had been actors, and Pamphilie continues that baptism led them to lose all their worldly possessions and their lives. ${ }^{735}$ Ardalion and Porphyrius are clearly two additional Genesius figures, actor-martyrs, who mock Christian rites on stage and then become Christians themselves and die a martyr's death. ${ }^{736}$ Genest, however, rejects his colleagues' suggestion, saying that one would not need to go that far to find the right material, and instead could easily find something appropriate in one's own life ("Mais sans chercher si loing le secours d'une Histoire / [...] / Nous pouvons rencontrer dans nostre propre sort, / De quoy plaire à Cesar qui nous prisera fort” 1.4). The emperor knew, after all, that they had left behind their homeland, relatives, and possessions in order to be able to stay far away from his enemies, the Christians, and to pay homage to the traditional gods. ${ }^{737}$ He therefore decides to dramatize an episode from his own life, determining on the spot the play's plot, characters, and distribution of roles ("l'ordre de ce mystere"):

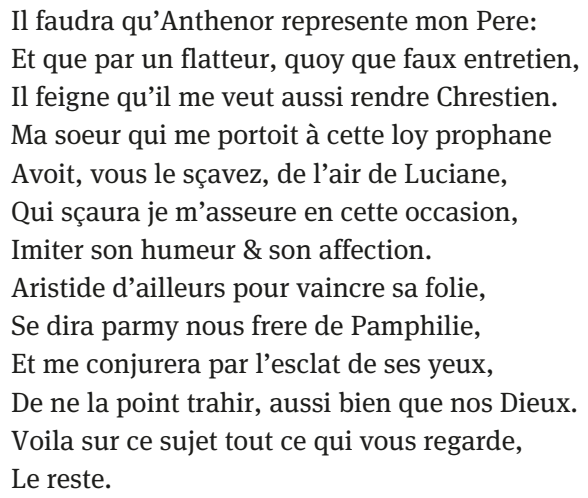

He selects Anthenor to play his father and Luciane his sister, both of whom want to convince him, Genest, to join them in becoming a Christian. Pamphilie

735 “ARISTIDE: Celle d'Ardaleon, ou celle de Porphire, / Qui tous deux bien aymez des maistres de l'Empire, / Furent par les Chrestiens tellement abusez / Qu'ils suivirent des voeux qu'ils avoient mesprisez, / Et par une folie à nulle autre seconde / Se rendirent l'opprobre \& la fable du monde. / LuCianE: Tous deux ont exercé nostre profession. / PAMPHILIE: Et le baptesme fut la premiere action / Qui flattant de ces fous la ridicule envie / Leur fit perdre à tous deux \& les biens \& la vie" (1.4).

736 At least the reference to Porphyrius is anachronistic, as according to legend he died in 362, many years after Genesius.

737 "GENEST: Il sçait que nous aurons quitté nostre Patrie, / Nos parens \& nos biens pour venir en ces lieux, / Loing de ses ennemis rendre hommage à ses dieux” (1.4). 
will act the part of his lover, Aristide that of her brother and their role will be to try and dissuade him from converting.

Thus, in Desfontaines there is also a blurring of the boundaries between actor and role, between real life and the stage. Similar to Ginés in Lope's first 'play within the play,' Genest wants to use his own life as fodder for the stage, and seeks to 'play' himself at a young age. Note that the characters in the 'play within the play' here are not given names, rather the actors have the same names as the characters they play. With respect to the fictitious relationships between the characters and the 'real' relationships between the actors, it should be noted that, despite not yet being apparent from the text, Genest and Pamphilie are also a couple in 'real life.'

The first act closes with Aquillin coming to give the actors gifts in the name of Dioclétian, and their subsequent praise for the Emperor and their stated desire to show reverence to him through art. The divertissement is ready to begin.

The second act is centered entirely on the 'play within the play.' In the first scene, the spectators - Dioclétian, Aquillin, Rutile, and the rest of the Imperial Court - take their seats. Dioclétian is curious to see whether the performance will have the desired effect on him, as Rutile had promised it would.

The play begins (2.2). Luciane does her utmost to persuade her brother Genest to convert to Christianity, imploring him tearfully. But Genest responds that there was nothing that could make him follow this "loy prophane," and even her tears were not enough to lead him to follow an unknown man who was put in chains and abandoned by his people. Luciane answers him by talking about the religious convictions of Christianity, and summarizing the birth, life, death, and significance of Jesus Christ. Genest, however, rejects everything as "un trompeur espoir [dont] vostre ame est possedée" and "vaine idée," and calls the divine power of the Caesars the 'true gods,' who they were meant to follow, as fate had made them their subjects ("Et puis que le destin nous a faits leurs sujets, / N'ayons pas en nos voeux de differents objets” 2.2). They see their father Anthenor coming towards them, and Genest asks Luciane to change the subject, since their father would not be very happy about this conversation, would certainly take Luciane's side and pressure him as well. When Anthenor joins them (2.3), he seeks to know whether his son was at last showing some discernment (i.e. whether he was ready to become a Christian and receive baptism). Genest declares that indeed he owed his father his existence and obedience, but that this concerned only his body. His mind, however, he had thanks to the gods and, accordingly, owed it to them to be devoted to them alone. The debate between them, in which Anthenor tries to convince Genest of the 'true faith,' culminates in that Anthenor angrily spurns his son and says that he will cast him out: 




In the next scene (2.4), a distraught Genest is speaking to his lover Pamphilie and his friend Aristide, Pamphilie's brother, and lamenting the situation: his father wants him to be baptized and become a Christian, and if not, he will be expelled and deprived of his inheritance, and, as a consequence, would have to leave Pamphilie as well; however, he could not act against his will and betray the gods. Pamphilie declares her love and loyalty to him ("Mais de quelques rigueurs dont le sort vous accable, / Fussiez vous en un point encor plus deplorable, / Je vous puis asseurer que ma fidelité / Sera jusqu'au tombeau sans inegalité" 2.4). Genest emphasizes his affection to her, but does not want to take her down with his misfortune. ${ }^{738}$ Aristide tries to calm his friend. He advises Genest to comply with his father's wish and be baptized but only for the sake of appearances! By pretending to be a Christian he will maintain the right to his inheritance and resolve the family dispute. This would not have any consequences for him, since, according to the Christians' "bizarre loy," their "mysteres" were powerless if one did not believe in them, with the result that, as his heart ultimately rejects their lunacy, the ceremony of baptism would be nothing but "un ridicule effet" for him (2.4). Aristide, who represents here what the Christians perceived as the corruption and hedonism of paganism, then goes on to say that pretending to a 'false devotion' will enable him to receive the 'true goods' (i.e., the material ones), and by means of some water (that is, by pretending to receive the Christian baptism) he could soothe the (domestic) storm:

Escoute les conseils que je te veux donner:

Tu nous dis qu'Anthenor te veut abandonner,

738 “GENEST: Mais encor qu'à ce point vous soyez genereuse, / Pouray-je consentir à vous voir malheureuse, / Et que tacitement il vous soit imputé: / Que sans moy vous seriez dans la prosperité? / Ha! Madame? souffrez qu'en ce desordre extréme, / Ma raison une fois parle contre moy-mesme, / Et qu'agissant pour vous, elle monstre en ce jour, / Par un estrange effect un veritable amour" (2.4). 


\author{
Et te priver à tort des droits de ton partage, \\ Si tu ne suis l'erreur où son ame s'engage, \\ Dy luy pour parvenir au but où tu pretens: \\ Que tu rendras ses voeux, \& ses desirs contens; \\ Et feints pour cét effect par un beau stratagéme, \\ Que tu veux comme luy recevoir le baptéme. \\ Suivant l'opinion de leur bizare loy, \\ Leurs mysteres sont vains quand on manque de foy; \\ De sorte qu'en ton coeur mesprisant leurs manies, \\ Tu n'auras observé que des ceremonies, \\ Qui n'ayans pas rendu le baptéme parfait: \\ N'auront produit en toy qu'un ridicule effect. \\ Acquiers toy de vrays biens avec de faux hommages: \\ Un peu d'eau, Cher Amy, calme de grands orages; \\ Fay que celle qui nuit à tous ses partizans, \\ Pour toy seule aujourd'hui produise des presens, \\ Et se rende pareille apres ton entreprise, \\ A la pluye envoyée à la fille d'Acrise. ${ }^{739}$
}

Genest argues that such a procedure would enrage the (true, pagan) gods. But Aristide contradicts him: on the contrary, it would honor them, since he was inwardly firm, despising and abhorring in his heart "cette loy nouvelle," and therefore soul would remain pure to worship at their sacred altars. ${ }^{740}$ When Genest asks Pamphilie for her opinion, she expresses the fear that he might regret it and that it could lead to a bad outcome for both of them. But Aristide scoffs at this, asking if she really believed that two drops of water would be able to extinguish the flame of his love (“[...] que deux gouttes d'eau / De son ardente amour esteignent le flambeau?” 2.4). Here, figuratively, the earthly 'false' love, the fiery passion, is opposed to 'true' Christian love, symbolized by the water (of baptism). It is precisely this erroneous assessment of the Christian sacrament's effectiveness, expressed by the pagan Aristide in the inner play, that will later be exposed as false when Genest openly professes his conversion to Christianity 'in earnest.' Genest is finally convinced by Aristide's arguments and Pamphilie as well also withdraws her objections, and the three decide to

\footnotetext{
739 The comparison with the Danaë-myth - Zeus comes in the form of golden rain to the daughter of Acrisius - places Genest in the context of the sin of avaritia; gold, material goods possess corrupting power.

740 “ARISTIDE: L'effect de ce conseil leur sera glorieux, / Puis qu'à l'aversion de cette loy nouvelle, / Tu joindras les mespris que ton coeur a pour elle, / Reservant à l'honneur de nos sacrez autels:/ Une ame toute pure, \& des voeux immortels” (2.4).
} 
put Aristide's plan in motion. They make up to meet again at the temple of Christians. ${ }^{741}$ This concludes the second act.

In the first scene of the third act, the spectators praise the excellent and highly convincing performance of all the actors. ${ }^{742}$

In the next scene (3.2), the 'play within the play' continues. A visibly disoriented and confused Genest appears: “Où suis-je? Qu'ay-je veu? Quelle divine flame, / Vient d'esblouïr mes yeux, \& d'esclairer mon ame? / Quel rayon de lumiere espurant mes esprits, / A dissippé l'erreur qui les avoit surpris? / Je croy, je suis Chrestien; \& cette grace extréme, / Dont je sens les effects est celle du Baptéme" (3.2). Genest believes that he is a Christian and has just received the grace of baptism. His fellow actors, both the Christians on the level of the inner play (Anthenor and Luciane) and the pagans (Pamphilie and Aristide), do not know what to make of his utterances. Pamphilie asks who made him a Christian, to which Genest does not react and simply replies that he was one (a Christian). Aristide suspects that Genest is dreaming, to which he replies that an angel has made him a Christian before the sight of all but, as Luciane observes, nobody witnessed this "aventure." The inner spectators, however, still

741 "PAMPH.: Je crains. / ARIST.: Que craignez vous? / PAMPH.: Tout. ARIST.: Dieux! quelle folie? / Vous craignez, dites vous, Quoy? que deux gouttes d'eau / De son ardente amour esteignent le flambeau? / PAMPH.: Non, mais que cette erreur à la fin ne luy plaise, / Et qu'elle n'ayt pour nous une suitte mauvaise. / GENEST: Ha! ne me croyez pas d'un esprit si peu sain. / PAMPH.: Vous pouvez donc agir, \& suivre ce dessein. / GENEST: Il faut adroitement conduire ceste affaire. / ARISTIDE: Laissez m'en le soucy, je verray vostre Pere, / Et je sçauray si bien mesnager ses esprits, / Qu'aveuglé de l'appas du dessein entrepris, / Il ne pourra jamais à travers mon adresse, / Se douter seulement du piege qu'on luy dresse; / Cependant finissant de si longs entretiens / Allez tous deux m'attendre au Temple des Chrestiens” (2.4).

742 For instance, according to Dioclétian, Luciane had played her role of the Christian so well, defended the aberration with such high art, and, in general, had pretended so well that at times he had thought it was not feigned ("N'as tu point remarqué ce qu'a dit Luciane / En faveur des Chrestiens \& de leur loy prophane? / Elle en a soustenu l'erreur avec tant d'art, / Que j'ay creû quelque temps qu'elle parloit sans fard, / Et que le trait dont lors elle sembloit atteinte, / Estoit un pur effect, \& non pas une feinte" 3.1). Also, Genest's excellent realization in the mockery of the Christian faith is highlighted ("RuTILE: Avec combien d'esprit, d'adresse, \& de courage, / Il a de nos autels conservé l'advantage? / Et par quel art enfin, \& quelle invention,/ Il se porte au mespris de leur religion? [. . .] sa subtilité n'eût jamais de pareilles” 3.1). Furthermore, in particular, the good representation of the passions is emphasized: "DiocL.: Que l'accord de leurs voix, \& de leurs actions, / Exprime adroittement toutes leurs passions! / Qu'ils se sçavent bien plaindre, ou feindre une colere! / Que l'amour en leur bouche est capable de plaire! / Et que leur industrie a de grace \& d'appas / À dépeindre un tourment qu'ils ne ressentent pas!” (3.1). 
believe that they are watching a scene from the play and praise his deceptively real performance:

PAMPHILIE: Chrestien? Qui vous l'a faict?

GENEST: Je le suis.

ARISTIDE: Resvez vous?

GENEST: Un Ange m'a faict tel.

ANTHENOR: Devant qui?

GENEST: Devant tous.

LUCIANE: Personne toutesfois n'a veu cette adventure.

RUTILE, à l'Empereur:

Il leur va debiter quelque estrange imposture.

AquiluIN: Qu'il feint bien!

Diocletian: Il est vray qu'on ne peut feindre mieux,

Et qu'il charme l'oreille aussi bien que les yeux.

Aristide accuses Genest of lying ("Tu nous contes des fables") when he speaks of a heavenly light that the others should have seen as well, and to the miracle bestowed upon him (“Quoy, vous n'avez pas veu cette clarté brillante, / Dont l'effect merveilleux surpassant mon attente, / Avecque tant d'eclat a paru dans ce lieu / Alors qu'il a reçeu le ministre d'un Dieu” 3.2). Genest insists on the truth of his words ("Non, Amys, je vous dis des choses veritables") and describes in detail the miraculous baptism that has just taken place backstage, and the miracle of his conversion to Christianity (“[...] ô merveille à peine concevable!”). He relates that when he was kneeling he turned his eyes to heaven and an angel had appeared before him:

[...] mille fois plus beau que le Soleil,

[...] qui me promettant un bonheur sans pareil, M'a dit qu'il ne venoit, si je le voulois croire, Que pour me revestir des rayons de sa gloire. Lors tous mes sens ravis d'un espoir si charmant: Ont porté mon esprit à ce consentement, Qui remplissant mon coeur d'une joye infinie A fait voir à mes yeux cette ceremonie, L'Ange, dont la presence estonnoit mon esprit, En l'une de ses mains tenoit un livre escrit, Où la bonté du Ciel secondant mon envie, Je lisois aisément les crimes de ma vie, Mais avec un peu d'eau que l'autre main versoit, Je voyoit aussi-tost que l'escrit s'effaçoit, 
Et que par un effect qui passe la nature,

Mon coeur estoit plus calme, \& mon ame plus pure.

Voila ce que j'ay veu, voila ce que je sens[.. ${ }^{743}$

He then begins to mock the pagan gods, saying he no longer feared them, and even hated them, that his heart was "embrazé d'une flame celeste," and he now adored only the one, omnipotent (Christian) God. ${ }^{744}$ Dioclétian demands that they stop the play - the performance, the feinte, was starting to displease him. But Genest continues, now addressing the emperor directly ("Il n'est pas temps, ô Cesar! de me taire" 3.2). The boundary between the first and second play levels is suspended and the stage of the inner play interactions with the inner audience. The Almighty God, ${ }^{745}$ Genest says, wishes him to go on ("le plus grand des miracles"): by the power of God he has been transformed from a hater and persecutor of Christians into a Christian himself ("[. . . ce Dieu souverain / De qui j'ay ressenty la puissance, \& la main, / Lors que je me pensois rire de ses oracles, / Vient d'operer en moy le plus grand des miracles, / Changeant un idolatre en son adorateur, / Et faisant un sujet de son persecuteur" 3.2). Without knowing it, he had (through the play) actually delighted the angels and the ruler of heaven ("Ne pensant divertir, ô prodiges estranges! / Que de simples mortels, j’ay resjouy des Anges, / Et dedans le dessein de complaire à tes yeux, / J'ay pleû sans y penser à l'Empereur des Cieux" 3.2). He now understands that his previous behavior was wrong and sinful and was the work of the devil, who had deceived his senses and seduced his mind. ${ }^{746}$ God had 'purified' his soul, and now his commitment to God and the proclamation of his omnipotence was his only goal. Dioclétian first claims that Genest has taken leave of his senses, but Genest immediately objects, declaring that when he

743 In describing the baptism, Desfontaines follows the legend model quite closely.

744 "GENEST: Et qui produit en moy des transports si puissans. / Loing de moy desormais estres imaginaires, / Fleaux des foibles esprits, \& des Ames vulgaires, / Faux Dieux, ce n'est plus vous aujourd'huy que je crains, / Ny ce foudre impuissant que l'on peint en vos mains: / Je ne vous connois plus, allez, je vous deteste, / Et mon coeur embrazé d'une flame celeste, / Adore un Dieu vivant dont l'extréme pouvoir, / Se faict craindre par tout, \& par tout se faict voir” (3.2).

745 "GENEST: Ce Seigneur des Seigneurs, \& ce grand Roy des Roys, / De qui tout l'univers doit reverer les loix, / Soubs qui l'Enfer fremit, \& que le Ciel adore [. . .]” (3.2).

746 "GENEST: Il est vray que privé de ses graces extrémes, / J'ay tantost contre luy vomy mille blasphémes, / Mais dans ces faux discours que ma langue estaloit, / Ce n'estoit que l'Enfer, \& non moy qui parloit, / Ce commun Ennemy de tout ce qui respire, / Qui par le crime seul establit son Empire: / Ayant trompé mes sens, \& seduit ma raison, / M'avoit mis dans le coeur ce dangereux poison: / Mais enfin de mon Dieu les bontez infinies, / Ont toutes ces horreurs de mon Ame bannies" (3.2). 
revered his (the emperor's) gods he was not in his right mind but that now he is completely sane, stressing: "Je me connois, Cesar, je sçais ce que je suis" (3.2). The clash between Genest and an increasingly furious Dioclétian continues, the emperor threatens Genest that he will be punished if he continues in this vein. Genest explains to the emperor that although he had power over his body, he had none over his soul ("Tu peux tout sur mon corps, \& rien sur mon esprit" 3.2). He encourages him to torture him, renounces all worldly things, and looks forward to the glory of heaven. Dioclétian orders his arrest and torture, but at the same time instructs Rutile to ensure that they would continue to attempt to change Genest's mind with promises and material things. ${ }^{747}$ In this respect Desfontaines' version differs substantially from both the legend and the Genesius plays already discussed. This is given coherence by the fact that the action of the inner play had already placed the 'fictitious' Genest in the context of avaritia. ${ }^{748}$ This motif is now taken up again on the level of the framing plot: the 'real' Genest, converted to Christianity, will not commit this sin, he will resist the material temptations and steadfastly die a martyr's death. Genest is taken away, and both the scene and the 'play within the play' or the play that has become serious, come to an end.

At this point, it is worth noting some differences between this and the other two Genesius plays. First of all, the initial situation of the 'play within the play,' is different. In the current play Genest stages an episode from his own life, describing how he had left his homeland and was abandoned by his family because he did not want to become Christian like them. Thus, Genest plays himself as a young man. His friend Aristide tries to convince him to deceive his father and become a Christian in name only, receiving baptism in order to retain his inheritance and remain close to his beloved Pamphilie, believing that the rites would only work if one believed in them. In contrast to the actual legend (where Genesius acts in a mocking farcical portrayal of baptism), and in contrast to Lope (where Ginés plays a Christian martyr) and Rotrou (where Genest also plays a Christian martyr, but, and this is the relevant distinction

747 “DiocL.: Va les suivre, Rutile, \& voy s'il est possible, / De reprimer l'orgueil de ce coeur invincible: / Menace, flatte, prie, importune, promets, / Offre luy des tresors, ouy, je te le permets, / Des charges, des honneurs, \& tout ce qui dans Rome, / Peut le mieux assouvir l'esperance d'un homme. / S'il se veut reconnoistre, \& quitter son erreur, / Son remords peut encor desarmer ma fureur; / Mais s'il s'obstine plus à faire le rebelle: / Qu'on l'expose aux ardeurs d'une flame cruelle, / Qui sur son corps perfide agissant peu à peu, / Avec mille douleurs le brule à petit feu" (3.2).

748 The decision for the fake baptism had been made, among other things, also on the basis of the argument of financial security, for as a 'Christian' Genest could be certain of his inheritance. 
from Lope, in this instance he portrays a 'real' character in a large-scale and elaborate drama), Desfontaines' Genest in the 'play within the play' is not persecuted by the pagan rulers, but must rather assert himself against Christians. To avoid this, he will - according to the script - fake being a Christian and only pretend to be baptized. Thus, the 'play within the play' is itself about pretense. Desfontaines' Genest plays himself: a pagan who plays being a Christian. The 'play within the play' is therefore being duplicated once more. However, this 'playing in the play within the play' skips over the actual baptism and conversion. In the third act, the actor Genest returns 'transformed' to the stage at the beginning of the scene; the miracle of his conversion and baptism, of which he reports, has taken place 'outside' the play, behind the scenes, between the acts, and without any witnesses. The selective nature of the miracle, the change from fiction to seriousness, from seeming to being, is thus represented much more radically in Desfontaines than in both Lope and Rotrou. We are not prepared for Genest's transformation, there are no rehearsal scenes as in Lope and Rotrou; Desfontaines' Genest's repertoire did not include the portrayal of Christians. Although the baptism in Rotrou (unlike in Lope) also takes place off stage, the miracle is still apparent to the audience: flames come from heaven, the request for baptism is part of the inner play, Genest/Adrian leaves the scene stating that he is following the call of an angel who appeared to him and wants to baptize him. In Desfontaines, the miracle is completely removed from the action on stage and is presented exclusively in the form of the report of the now converted Genest. If previously, on the level of the inner play, the effectiveness of the sacrament of baptism is called into question, here it is a miraclulous instance of God bringing about the sudden conversion of a declared enemy of the faith (who - at least in the 'play within the play' - is a creature of earthly vice, material greed, and sensual love) that appears all the more impressive. The whole problematizing of the distinguishability between appearance and being, play and seriousness - a focus of Lope's drama - is almost entirely lacking here, and only a very temporary state of 'confusion' can be observed. This initial disorientation on the part of the players and the inner spectators is quickly resolved, and the authenticity of Genest's confession is soon accepted. Furthermore, it should be noted that acting metaphors, prevalent in Lope's drama and in that of Rotrou (albeit to a lesser extent), are not to be found in Desfontaines. In Desfontaines, Genest does not refer to the 'world as stage' and life as the role we play in it. In addition, the different settings of the inner play are also of importance: whereas the 'play within the play' in Lope and Rotrou are framed as entertainment put on as part of the celebrations of the imperial court, in Desfontaines, the purpose of the performance is to test its potential as propaganda. This intention - to solve the 'Christian problem' by means of the 
theater - is caricatured as a failure, and has the opposite effect by causing the conversion of Genest. It does not seem possible to just 'play' a 'confessing Christian.,749

After the 'play within the play' is aborted and Genest arrested, Dioclétian turns, enraged, to the remaining actors (3.3). He, and this is another difference from the other two Genesius dramas, does not order any investigation to clarify whether or not they are also Christians, but instead accuses them of being Christians and of having seduced Genest (not vice versa) ("Vous l'avez suborné, vos propos l'ont seduit” 3.3). He therefore threatens them with punishment. The actors defend themselves vehemently and affirm their innocence. Pamphilie declares that they were innocent and had always been loyal to the emperor and the gods. ${ }^{750}$ Anthenor emphasizes that the play was fiction and that he was not in fact Genest's father, and that they had only 'imitated' Christians (imiter) and, furthermore, had in fact only done so at the instigation of the 'traitor' Genest. ${ }^{751}$ Luciane adds that Genest had acted contrary to their knowledge and had shown himself criminal by confessing to Christianity, and they condemn and detest his actions. She had used the Christians' words in the play with the sole intention of mocking them. Thereupon, Dioclétian, appeased, orders her to prove her art of persuasion by using all the means at her disposal to get Genest to recant. ${ }^{752}$ Luciane suggests that, in order to guarantee success,

749 Cf. as well Laemmel's comment on this: 'The moral-didactic thesis of the two French Genesius versions coincides insofar as in both the attempt to simulate a professing Christian fails: In view of the mystères terribles [Boileau, L'art poétique, Chant III, vv. 199 f.] of faith, all stage art proves to be null and void.' ("Die moralisch-didaktische These der beiden französischen Genesius-Versionen deckt sich insoweit, als in beiden der Versuch, einen bekennenden Christen zu simulieren, scheitert: Angesichts der 'mystères terribles' [Boileau, L'art poétique, Chant III, vv. 199 f.] des Glaubens erweist sich sämtliche Bühnenkunst als nichtig”) (“Zur Adaptation einer 'comedia de santo' in Frankreich" [cf. note 494], p. 470).

750 "РАмPH.: Quel est donc le forfait qui nous rend si coupables? / De quelles trahisons nous penses-tu capables? / Nous n'avons point chocqué ny les Dieux ny l'Estat, / [ . . ] / Prononce si tu veux l'arrest de mon trespas, / Tu me verras mourir \& constante \& contente; / Mais espargne, ô Cesar, une troupe innocente, / Qui dans tous ses desseins a tousjours prudemment / Regardé son devoir, \& ton contentement" (3.3; my italics). Pamphilie's later conversion is already indicated here, she too will be ready to die for the new faith.

751 “ANTHENOR: Luciane, Seigneur, ne fut jamais ma fille, / Je n'eûs jamais d'enfans, je n'ay point de famille, / Et bien que nous ayons imité les Chrestiens, / Nous n'avons point pourtant d'autres Dieux que les tiens. / Tous ces noms supposez \& de fils, \& de pere, / Ses desirs simulez, \& sa feinte colere, / N'estoient que des effets que nous avoit prescrits, / Ce traistre dont le change estonne nos esprits" (3.3).

752 "Diocl.: Si tu repugnes tant aux abus des Chrestiens, / Fay nous voir des effets du discours que tu tiens, / Va t'en trouver Genest, \& t'efforce d'abattre, / Par de vives raisons ce 
Pamphilie should also make an attempt ("l'heureux effort de ce coup glorieux, / Appartient à sa langue aussi bien qu'à ses yeux" 3.3). The latter refuses, however, saying that Genest's betrayal of her was too great. Obviously, the relationship between Genest and Pamphilie depicted in the inner play corresponds to reality; in real life, too, they were a love couple. She continues, wild with rage, that if Genest, "cet ingrate," (3.3) did not change his ways, Dioclétian should leave him to her instead of the executioners, because there was nothing comparable to the anger of a woman betrayed. The emperor acknowledges her request and decides that, if Genest does not change his mind, he will leave him to her anger. This concludes the third act.

The fourth act of Desfontaines' Genesius tragedy features a motif found neither in Lope nor in Rotrou, but rather in Corneille's influential martyr tragedy Polyeucte $^{753}$ : a (miraculous) imitation of the heroic martyr. At the end of the act, Pamphilie converts to Christianity, confesses her new faith to the Emperor, and awaits martyrdom. Although in the inner play of Le Véritable Saint-Genest, Natalie, Adrian's wife, is a secret Christian, as far as the framing play is concerned, only Genest or Ginés profess the new faith and ultimately die a martyr's death. ${ }^{754}$ In Polyeucte, after the protagonist has died a martyr (his own conversion was moreover preceded by that of his friend Néarque), his wife Pauline, who had tried to persuade him to repent, and Félix, Polyeucte's father-in-law and the Roman governor of Armenia, who had arranged for his execution, are also 'struck by the miracle of divine grace' and convert to Christianity. In Rotrou's drama, the actress Marcelle also attempts to persuade Genest, in prison awaiting execution, to change his mind, but Genest and Marcelle are not in love, as is the case with Desfontaines' Genest and Pamphilie, and Marcelle does not end up converting. The turning away from the false, earthly-erotic love to the true love of Christ, so prominent a theme in Lope's drama, can also be found in Desfontaines' work. In order to persuade Genest to renounce his faith Diocletian orders Pamphilie to go see him. She expresses to herself her feelings towards him - she still loves him, but at the same time feels rage at his betrayal (and says that the latter emotion should be restrained, the former not

coeur opiniatre. / L'adresse de l'esprit jointe aux graces du corps, / Faict ordinairement d'admirables efforts: / Employe un peu tes yeux au secours de ta bouche, / Il n'est point de mutins qu'un bel objet ne touche; / Desja mon courroux cesse, \& cede à tes attraits, / Fay que Genest encor en ressente les traits, / Et que son coeur vaincu par de si belles armes, / Nous rende redevable au pouvoir de tes charmes" (3.3).

753 See above note 725.

754 It should also be pointed out here again on the 'presence' of Christians in the inner play of L'Illustre Comédien (Anthenor, Genest's father, and Luciane, his sister). 
be openly shown). ${ }^{75}$ In the third scene of the fourth act, the two lovers meet. In response to Pamphilie's accusations that his actions had betrayed her and the gods, ${ }^{756}$ Genest explains that on the contrary he had betrayed her earlier by his false, sensual loving: "[...] je vous trahissois, quand mon ame aveuglée, / Ne concevoit pour vous qu'une ardeur dereglée, / Et subornant mon coeur par d'injustes desirs, / Vous aymoit beaucoup moins que ses propres plaisirs" (4.3), but now his love for her was 'pure' and 'true': "Mais, Madame, aujourd'huy que $m a$ flame est plus pure, / Que le feu n'est là haut au lieu de sa nature, / Qu'un veritable amour me porte à vous cherir, / Jusqu'à vouloir pour vous tout quitter \& mourir;" (4.3; my italics). When Pamphilie reproaches him for having abandoned and betrayed her, Genest replies that betrayal was good and innocent, while loyalty was reprehensible and criminal when it referred to a tyrant, to terrible and harmful gods; how sweet, in contrast, it was to free oneself from a hateful yoke and submit oneself to the laws of an admirable monarch whose castle and court were in heaven, who was exclusively clemency, justice, and

755 At the beginning of the fourth act, Aristide tells Pamphilie that Genest could not be persuaded to recant and that he was to be brought to her at the behest of Rutile. When asked what she should do, he replies that, after all, she knew 'this traitor' best. Pamphilie replies that he had deceived her as much as he had deceived all the others. But Aristide notes that she was the only person left whose anger he still feared, this was shown by the fact, he continues, that the mention of her name and her beauty still affected him, that he could not hold back sighs and tears. Pamphilie, however, in view of his betrayal, also doubts the genuineness of his feelings for her, that his tears were by no means certain indications: "Apres ses trahisons \& des mespris si grands, / Ses pleurs \& ses souspirs sont de foibles garands: / Il a changé l'ingrat, \& quoy que l'on presume, / Ce qu'il fit par amour il le fait par coustume" (4.1). Aristide reminds her that it is an order. Pamphilie is willing to gather all her love and hatred to defeat Genest's zeal. In a monologue, Pamphilie prepares for a meeting with Genest (4.2). Her speech revolves around the 'tyrants of her soul,' her furor, hatred, contempt, revenge, and love and the question of which direction her passions will take and which emotion will prevail in the end. She concludes her reasoning with the insight that she still loves Genest, that despite his crime and error she has to restrain her anger, but at the same time she has to hide her weakness from him.

756 Pamphilie accuses him of the injustice he has done to her through his actions, calls him 'disloyal' and a traitor ("ame traisteresse"), and wishes a severe punishment for him. She would even be punished much worse than him because of his offenses, although she had not rebelled against the gods and the Empire. As Genest answers that he comes to her in humility and asks her for the reason of her anger, Pamphilie responds sharply: "Quel forfaict, desloyal? ô Dieux quelle impudence! / Il est la vertu mesme; \& la mesme innocence, / Il n'a jamais manqué ny d'amour ny de foy, / Il n'a jamais trahy ny l'Empereur ny moy, / Il ne parla jamais en faveur du Baptesme, / Sa bouche n'a jamais proferé de blasphéme, / Des crimes, justes Dieux! il n'en a point commis, / Et vous avez grand tort d'estre ses ennemis: / Insolent, est-ce ainsi que tu veux qu'on te flatte?" (4.3). 
love; if only, like him, she could receive the enlightening beam of divine grace and appreciate the happiness of being a Christian, she would care less about vain earthly concerns. ${ }^{757}$ Then he addresses his words to God and asks him to give 'true love' to Pamphilie as well (also for his own sake):

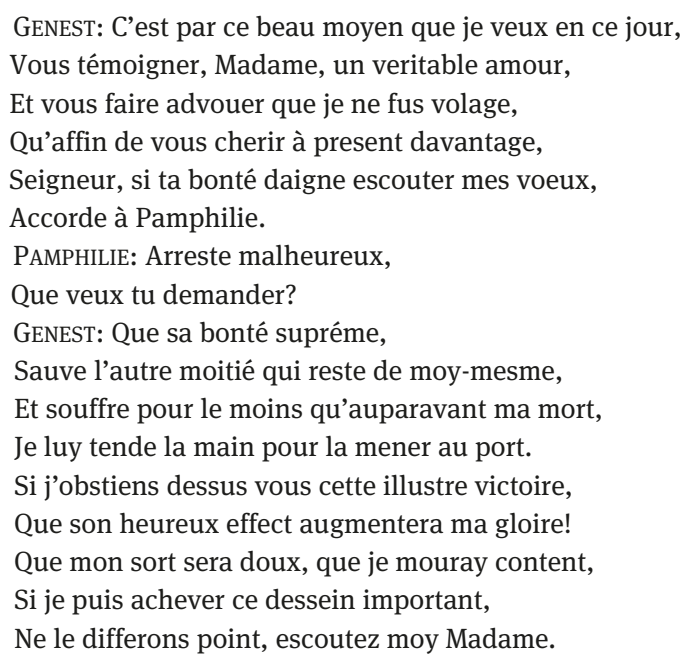

Pamphilie points out that he is trying in vain to seduce her soul. But Genest continues in his attempt to convince Pamphilie of the 'true faith.' The (pagan) gods were powerless demons that had never demonstrated their alleged power on earth. Worshipping them was pointless, as they were merely the invention of mortals and had not created a single particle of the world. Creator and ruler of the earth, of men and of the whole universe was the only God whom he was worshipping, of whom he knew nothing before, but who had showed him his power. And he wished for Pamphilie's soul to see this as well, to receive the same blessing. She should no longer refuse to it, because through this divine grace her soul would be forever connected to his, their hearts would be merged, and in this she can see how strong his love for her was: "Et pourveu que vostre

757 “GENEST: Ha! si vous connoissiez, ma chere Pamphilie, / La nuit où vostre erreur vous tient ensevelie, / Et si par le secours de cét astre charmant, / Dont l'esclat m'a tiré de mon aveuglement, / Vous pouviez recevoir un rayon de la grace, / Qui met dedans mon coeur une si noble audace / Qu'au prix de vostre sort vous beniriez le mien, / Que vous estimeriez le bonheur d'un Chrestien? / Et que pour en porter les glorieuses marques, / Vous feriez peu d'estat de celles des Monarques” (4.3). 
ame ayt desir de le voir, / Cette mesme faveur est en vostre pouvoir, / Ne la refusez point, ma chere Pamphilie, / Que par elle vostre ame à la mienne s'allie, / Et souffrez qu'aujourd'huy par un si beau lien, / J'unisse pour jamais vostre coeur \& le mien, / Voyez combien pour vous mon amour est extréme" (4.3). By speaking of the Christian idea of being united forever in eternal life, Genest affirms that he loved her more than himself, that in order to save her and win her he would endure torture and suffering, that he would be filled with joy if he achieved her happiness with his blood. ${ }^{758}$ "Hélas!" Pamphilie calls out. Genest interprets this as an expression of her fear of death. ${ }^{759}$ But Pamphilie explains that the sigh was an expression of her repentance, not her weakness. She was following him, that his God was now reigning in her heart as well. She was already completely overwhelmed by this joy, and now full of envy she looked at his chains, seeing them now as hers as well. ${ }^{760}$ Thus, Pamphilie becomes a Christian and is joyfully looking forward to a martyr's death. Genest's request has been granted. The miracle of Pamphilie's conversion, like that of Genest's conversion, is not shown openly on stage, but remains in its depiction limited to the realm of inwardness.

In the following scene (4.4), Pamphilie - now a Christian, as, however, only the audience/readers know - appears before the Emperor, with the captive Genest and the other actors also present. Here too - this time on the first playing level - there is a brief moment of confusion, a misunderstanding of what is being perceived. Rutile notes a joy shining from Pamphilie's eyes, the origin of which he associates, however, with the plan to make Genest recant, and thus interprets it as an expression of Pamphilie's success in dissuading Genest from his 'misbelief' (“[...] elle a sans doute emporté la victoire, / Une visible joye esclatte dans ses yeux" 4.4). When Dioclétian asks her what she did "en faveur

758 "PAMPH.: Tu m’aimes. / GenEST: Ouy, Madame, \& bien plus que moy-mesme, / Puisque pour vous sauver \& pour vous acquerir, / Quelques rudes tourmens qu'il me faille souffrir, / Quelque suplice affreux que la rage desploye, / On m'y verra courir avec beaucoup de joye, / Pourveu que par mon sang je vous puisse achepter, / Un bonheur qu'avec moy vous devez souhaiter" (4.3).

759 "GENEST: Vous souspirez, ha! sans doute la crainte, / Combat vostre desir, \& le tient en contrainte, / Vous redoutez la mort, un Tyran vous faict peur" (4.3).

760 "PAMPH.: Non, non, ne pense pas que je manque de coeur, / Ce souspirs qu'a produit une sainte tendresse / Montre mon repentir, \& non pas ma foiblesse, / Je te suy, cher Amant, je te cede, \& je croy; / Ton Dieu regne en mon coeur, \& triomphe de moy. / Desja de ce bonheur je suis toute ravie, / Et regardant tes fers avec un oeil d'envie, / Je brule qu'un Tyran n'ordonne à ses boureaux, / De passer en mes mains ces illustres fardeaux. / Ne pouvant les ravir qu'au moins je les soustienne, / Ouy ces fers sont mes fers, cette chaine est la mienne, / Puisque par les effects d'une douce rigueur, / Elle passe à present de tes mains à mon coeur” (4.3). 
de nos Dieux," Pamphilie answers: "Plus que je ne devois" (4.4). Dioclétian does not want to deprive them, the actors, of a generous reward for their efforts to convince Genest, even if they were not successful, but it was now necessary to fight Genest with more severity. The actor Aristide reaffirms their humility and praises the emperor and his generosity. Thereupon, Pamphilie accuses him of flattering subservience and openly reveals herself to be a Christian. She refers to the nothingness and deception of the world and material goods in contrast to the eternal and true happiness in the hereafter and now for her part tries to convince Aristide of the 'true' faith. Then she speaks to Dioclétian: the reward he could give her (i.e. the order of her execution) was a far greater gift than what he had given the other actors, because, as she says explicitly at the end of her speech, "Je suis Chretienne” (4.4). Pamphilie's fellow actors react with horror to her confession and suspect (correctly) that Genest is responsible (“ANTHENOR: Le traistre l'a charmée" 4.4). ${ }^{761}$ Full of anger, Dioclétian commands Rutile: "Frappe ces insolens, \& les reduits en poudre" (4.4). At first, however, only Genest is transported away.

What follows in the next scene, the last of the fourth act (4.5), is an element typical of depections the lives of martyrs, namely the martyr's steadfastness and unwillingness to recant before the ruler of the persecutor of Christians, here between Pamphilie and Dioclétian. In contrast to Lope but similar to Rotrou, Desfontaines amplifies the aspect of the discursive representation of the new faith, the concrete, literal confrontation between 'converted Christian' and 'enemy of Christians,' the persuasion (Genest-Pamphilie) and the constance. Pamphilie laments the 'false benevolence' in not being thrown into prison with Genest, saying that she wished to die with him and that what love had brought together could not be separated. Dioclétian in turn states that he wanted to give her the opportunity to recant, she would have done better to appeal to his clemency, but would now receive the same punishment as Genest. ${ }^{762}$ Pamphilie refers to the heavenly glory that torture and death would bring and affirms their "noble courage" (4.5) to be able to endure everything steadfastly. Dioclétian points out that she was mistaken if she trusted in a God who could not even save himself from death, and reminds her of his own power. This is followed by Pamphilie delivering what amounts to a sermon in

761 And not suspecting that she was already a Christian before, had deceived them, and it was she who had converted Genest. This possible interpretation was, after all, the one Dioclétian first considered after Genest was taken away and the play abruptly ended.

762 "DiocL.: Mais apres ce refus n'espere plus de grace, / Un mesme sort suivra vostre commune audace, / Et puis qu'un mesme crime a bien pû vous unir, / Un mesme chastiment vous peut aussi punir" (4.5). 
defense of the Christian faith, in which she contrasts the omnipotence of the one true God with the vain power of the mortal emperor Dioclétian. With Dioclétian's warning that his wrath would show her that he was her true ruler, and the order to execute her before her lover's eyes, the fourth act ends.

The beginning of the fifth act focuses on the further fate of the remaining actors Anthenor, Luciane, and Aristide. Unlike in Lope and Rotrou, they are not negatively affected by Genest's conversion. On the contrary, they enjoy a good position at court, and are in Dioclétian's favor. Anthenor emphasizes this state of affairs when he inquires confusedly about the reason for Aristide's displeasure and sadness; especially since, as Anthenor further stresses, he can be sure of Luciane's love and affection for him. From this we understand of course that Aristide and Luciane are lovers as well. Aristide replies that he was, of course, mourning the impending death of Genest and Pamphilie. However, Luciane is jealous and thinks that the real reason for Aristide's despair is because he is in love with Pamphilie. This exchange highlights the aspects of deception and perception here negotiated in the context of love. Luciane interprets Aristide's tears as proof of his true love for Pamphilie, declaring that that his compassion was only feinte and his sobbing an indication of his soul's pain and his love's sorrow; language enabled one to pretend (dissimuler) but the body reveals what is real; thus, she was only now able to recognize that his feelings for her had been nothing but deception, ${ }^{763}$ and full of rage, she storms out. Aristide wants to follow her immediately in order to convince her that she was mistaken and her accusations false, that he loved her and that his pity for Pamphilie (and Genest) was genuine and did not mask an erotic passion. Anthenor, however, holds him back, her anger would calm down by itself after a while. Aristide

763 "LuCIANE: Certes ces sentimens ont beaucoup de tendresse, / Et si je ne me trompe encore plus d'adresse, / Puis qu'ils sçavent si bien desguiser en ce jour / D'un masque de pitié ta feinte, \& ton amour. / Mais c'est en vain ingrat que ton ame insensée / Presume me cacher le traict qui l'a blessée, / Ton alteration ne me fait que trop voir / La cause de ta flame \& de ton desespoir, / Quand par des coups si grands un coeur se sent atteindre / Il est bien malaisé de souffrir \& de feindre, / La langue quelquefois peut bien dissimuler, / Mais quand elle se tait, les yeux sçavent parler, / Et le coeur trop pressé des ardeurs de sa flame / Montre par ses souspirs les blessures de l'ame. / [...] / [. . ] autrefois tes feintes passions / Trompoient mon innocence, \& mes affections: / C'est ainsi qu'autrefois Luciane abusée, / N'estoit à ton esprit qu'un objet de risée, / Cependant que ton coeur autre-part arresté, / Brusloit secretement pour une autre beauté: / Mais enfin aujourd'huy ma raison mieux reglée / Dechire le bandeau qui m'avoit aveuglée, / Et s'il me reste encor quelque feu dans le sein, / J'en conserve l'ardeur pour un autre dessein. / Ayme, ayme desloyal, ayme ta Pamphilie, / Suy mesme apres sa mort la chaine qui te lie, / Et si ta lascheté n'empesche un coup si beau, / Va, malheureux amant la rejoindre au tombeau: / Va, que differes-tu? ne croy plus me surprendre” (5.1). 
contradicts this vehemently (her negative remarks about him in this state could also leave him in a bad light before the emperor) and they eventually follow Luciane (5.2).

In the next scene (5.3), Dioclétian asks Rutile about the progress and result of Genest's torture. The tortures had not had any effect until now, Genest was enduring all of them steadfastly, even with pleasure ("On diroit que son coeur y trouve des delices, / Et qu'alors que son sang coule de tous costez / Il nage dans un bain parmy des voluptez" 5.3). There was no method of torture that had not been used, he had endured them all and his courage only increased. Even the executioners were more touched by his pain than he was and "[...] tandis que chacun plaint ou pleure son sort, / Luy seul void sans trembler l'appareil de sa mort" (5.3). Dioclétian concludes that Genest must be endowed with magic power ("Sans doute il s'est muny de la force des charmes") and asks about Pamphilie. Then Rutile gives an extensive and detailed description of the torture scenario ("un spectacle où j'ay peine à bien croire mes yeux. / Pourtant puis qu'il te plaist, escoute une advanture / Inouye \& nouvelle à toute la nature" 5.3), which is more detailed than in Rotrou. Pamphilie, too, was showing no fear and was enduring every imaginable torture of herself and her lover as steadfastly as Genest, both emphasizing repeatedly the happiness of dying together, the suffering of the body perceived as "joyaux precieux" and the prospect of the subsequent "sainct [h]ymen."764 Even the cruelest torture was not affecting Genest ${ }^{765}$ the people were impressed by his constance and if he did not die soon he, Rutile, was afraid that riots might break out: "Il dit que de ses maux le plus grand est de vivre, / Et je crois, ô Cesar, qu'il n'en faut pas douter: / Mais d'ailleurs s'il ne meurt il est à redouter; / Et je crains que le

764 "Rutile: Voids, a dit Pamphilie, ô merveilleux vainqueur, / Voids, ô mon cher Amant, si je manque de coeur, / Si proche du trespas regarde si je tremble. / Non, non, je ne crains rien, mourons, mourons ensemble, / Et puis qu'un sainct Hymen nous doit joindre là haut, / Que nostre sang versé sur ce cher eschaffaut / En signe les accords, \& soit le premier gage / Que nous aurons donné de nostre mariage. / Ces fers nous tiendront lieu de joyaux precieux, / Ce funebre appareil de lit delicieux, / Les boureaux d'Officiers, \& toute l'assistance / De pompe, d'ornement, \& de magnificence. / [...] / Enfin estans tous deux en estat de souffrir / On les void à l'envy l'un \& l'autre s'offrir, / Et comme en un combat plein d'honneur \& de gloire / Se disputer tous deux cette triste victoire / Dont le sanglant effet estonne les esprits, / Et de qui le trespas est la fin \& le prix" (5.3).

765 E.g.: "RuTILE: D'abord pour effrayer cette jeune arrogante, / L'executeur en main prend une torche ardente, / Et sur Genest enfin commençant ses efforts / Fait agir sans pitié la flame sur son corps, / Le feu court, \& produit un effet pitoyable; / Il touche tout le monde horsmis ce miserable, / Qui d'une vive ardeur à demy consumé / Semble au lieu d'en mourir en paroistre animé. / Nous restons tous confus, le boureau perd courage” (5.3). 
peuple esmeu de sa constance / Ne se porte à la fin à quelque violence” (5.3). Dioclétian then orders their immediate execution.

Dioclétian asks himself (5.4) what it is that drives Christians. They would rather be executed together in public than worship the gods, ask him for mercy, and be able to live with joy, honor, and fortune. They would shed their blood, waste their lives, enchanted by a false hope; there was no punishment, no torture that could dissuade these godless people from their blindness. One would have to tame their boldness or extinguish them altogether. The play thus contrasts the 'false' hedonistic life of the heathen with the 'true' life and triumphant faith of the Christians.

After that, Aquillin appears (5.5) and Dioclétian inquires whether there have been any riots. Aquillin answers that on the conrary the entire people love him and fear his power, and that the fear of death or the respect for the gods hold back even the most daring. However, a 'sad incident' ("triste accident") had occurred, which had moved him deeply ("me touche au dernier point"): on his way back to the palace after Pamphilie's execution "[u]n spectacle d'horreur, de tendresse \& d'effroy" had taken place before his eyes (5.5). He had seen Luciane “[d]e quelque desplaisir [...] blesse," plunge from the highest bridge into the Tiber (5.5). Aristide arrived just in time to see his beloved disappear into the river and immediately began to throw himself in after her. Anthenor tried to physically hold him back and in the ensuing scuffle both fell to their deaths. The Emperor should judge for himself, but, as far as he was concerned one could not witness such "coups prodigieux" without feeling pity. ${ }^{766}$ Dioclétian agrees with him that this event must indeed touch even the hardest soul, ${ }^{767}$ but Aquillin should still focus his compassion and sympathy on him, the Emperor, for despite his greatness and the splendour of Rome, he was, in the end, a lonely, hated man, a horror to men and gods. ${ }^{768}$ Aquillin immediately seeks to comfort him, that he alone was ruler, that all the world

766 “AquilLin: Voila ce que j’ay veu, juge s’il est possible / De voir un tel malheur \& paroistre insensible, / Non, Cesar, \& quiconque a du coeur \& des yeux, / Ne void point sans pitié ces coups prodigieux" (5.5).

767 "DiOcL.: Je l'advoue avec toy, cette estrange adventure / Auroit esté sensible à l'ame la plus dure, / Et le coeur d'un barbare en cette occasion, / Eust eu tes sentimens, \& ta compassion" (5.5).

768 "DiocL.: [. . .] reserve ta voix, tes souspirs, \& tes pleurs, / À plaindre desormais l'excez de mes malheurs, / Ouy, ouy garde à mon sort ta pitié toute entiere, / Elle ne peut avoir de plus ample matiere. / Puis que ceux que le ciel void d'un oeil rigoureux / Peuvent au prix de moy se reputer heureux. / Ouy, malgré mes grandeurs \& les pompes de Rome, / Je connois, Aquillin, enfin que je suis homme, / Mais homme abandonné, mais un homme odieux, / Mais un homme l'horreur des hommes \& des Dieux" (5.5). 
feared him and respected his laws, that the throne was a place that fear could not reach, that the eyes of all men were on him, that he would not die until the whole universe was destroyed. ${ }^{769}$ Dioclétian, however, dismisses this as useless flattery (“[...] pour me guerir du mal qui me possede / Un langage flatteur est un foible remede” 5.5).

The pangs of conscience, torment, and fear experienced by Dioclétian, the enemy of Christianity, are the themes of the closing monologue of Desfontaines' Genesius-tragedy. The shaken emperor falls into a lamentation full of remorse and despair, recognizes the void of his life and power; his heart and soul are battlefields, full of horror, despair, guilt, and terror; the world appears to him to be in decline; anger, despair, and pain would kill him. ${ }^{770}$ Suddenly, however, he feels relief from his pain and torment ("Ha! ma douleur s'appaise \& ma frayeur s'oublie” 5.5) brought about by a divine appearance. He describes how the heaven suddenly shines bright ("Mais quel astre nouveau brille dans cette nue? / Quelle divinité plus belle que le jour / Daigne encore esclairer ce funeste sejour?" 5.5) and he sees Genest and Pamphilie, both wearing a crown and holding palm fronds in their hands ("Au ciel je vois Genest avecque Pamphilie, / De mille beaux objets tous deux environnez, / Tous deux la palme en main, \& tous deux couronnez" 5.5). He asks the two 'shadows' ("Cheres ombres") for forgiveness and for their celestial power to calm the terrible storms that oppressed his mind; he had been cruel and full of anger. ${ }^{771} \mathrm{He}$ promises to honor them adequately, wants to set them side by side with his gods and build impressive mausoleums for them that even after centuries

769 "AquilLin: Que dites vous, Seigneur, quelle douleur si forte / Peut si soudainement vous troubler de la sorte? / Tout vous craint, tout flechit, tout revere vos loix, / Et seul vous commandez à la Royne des roys, / Chassez donc la frayeur dont vostre ame est atteinte, / Le trosne est un azile où ne va pas la crainte, /Tout le monde sur vous ayant les yeux ouvers / Vous ne sçauriez perir qu'avec tout l'univers” (5.5).

770 "DIOCL.: En vain je porte un sceptre, en vain une couronne, / En vain un monde entier me suit \& m'environne, / En vain je suis Monarque, \& Monarque vainqueur, / Si tous mes ennemis sont desja dans mon coeur, / Si je sens en mon ame une guerre cruelle, / Si je me suis moymesme à moy-mesme rebelle, / Et si par tout en fin je traine avecque moy / L'horreur, le desespoir, le remords \& l'effroy, / Tout me paroit fatal, tout me semble funeste, / Le jour troublé d'esclairs, l'air infecté de peste, / Le ciel rouge de feux, \& la terre de sang, / Le Soleil sans lumiere \& sorty de son rang. / Ô Dieux! ne vois-tu pas ces fantosmes terribles / Qui font autour de moy des hurlemens horribles? / Entends-tu comme moy ces longs gemissemens / Dont les tristes accens troublent mes sentimens? / Ô rage, ô desespoir, ô douleur qui me tue!” (5.5).

771 "DiocL.: Cheres ombres, pardon, \& du ciel où vous estes / Calmez de mon esprit les horribles tempestes, / Je fus en vostre endroit cruel, \& furieux" (5.5). 
would still shine as an expression of their innocence and his remorse. ${ }^{772}$ But then everything darkens again, despair and fear return. Now, he angrily invokes 'his' gods (calling them "injustes," "inhumains," "ingrats" 5.5), asking them to ease his pain and torment. He declares that he had honored and defended them and if they did not want to be seen as powerless, they should alleviate his pain, and he concludes with the words: "Mais s'il faut, Dieux ingrats, enfin que je perisse, / Achevez vos rigueurs, \& hastez mon supplice” (5.5).

While Lope's drama closes with Ginés bound to the stake, using the metaphor of theatrum mundi to speak of his sense of fulfillment and satisfaction, and anticipation for the rewards of eternal life, and Rotrou's play ends with a report of Genest's glorious death, called the end of a tragedy, and the reaction of his former spectators and co-actors; in Desfontaines it is the anguished persecutor of the Christian faith who ends the play and expresses its final argument. The martyrs Genest and Pamphilie appear to Dioclétian as saints in heaven, but this divine intervention, is not (yet) an expression of his conversion, although he does deny the validity of earthly existence, admits his crimes, and asks the martyrs for forgiveness, but does so within a polytheistic context; he turns again to his pagan gods, but doubts their power. The ending thus proclaims the victory of Christianity, the right faith, and the omnipotence of divine grace over cruel, sinful, and materialistic paganism.

In the other two Genesius dramas, only the protagonist dies. In Desfontaines' tragédie, however, all five actors in the troupe die. Genest and Pamphilie die for the 'true faith;' Luciane, Aristide, and Anthenor, clinging to false faith, die in a triste accident, a pitiful spectacle d'horreur, de tendresse \& d'effroy. The destructive power of passion and false love is contrasted with the true love of Christ. Genest and Pamphilie's passion is transformed by their conversion into 'true love' and both die united in faith, '[...] nostre sang versé sur ce cher eschaffaut / En signe les chords, \& soit le premier gage / Que nous aurons donné de nostre mariage.' Neither the scaffold nor the theater are able to contain the spread of Christianity, but instead promote it, so that at the end of the play the all powerful Emperor and persecutor of Christians is left behind alone and in desperation.

I will now summarize the comparison between Lo fingido verdadero and Le Véritable Saint-Genest focusing on the use of skepticism, the element of the 'play within the play,' and the context in which the plays originated.

772 "DiocL.: Mais je vous vay ranger au nombre de nos dieux. / Je vay vous eslever d'illustres mausolées / Qui toucheront du faiste aux voultes estoilées, / Et serviront de marque aux siecles à venir, / Et de vostre innocence, \& de mon repentir” (5.5). 
It is clear that Rotrou used Lope's dramatization of the Genesius legend as a model for his own play, particularly when considering how different it is from the other French Genesius drama by Desfontaines. Yet what is striking is how far he strays from this model. Rotrou opts not to adopt the most predominant feature of Lope's comedia, namely the ongoing destabilization (present at all levels of the plot) of the border between seeming and being, illusion and reality. The transformation of the material from Spanish comedia to French tragedy is further expressed by the excising of all comic elements, and an emphasis on unity and order, a reduction and concentration of dramatic personae, place, time, and action. At the same time, the tragedy creates a space of reflection and rational debate. While Lope's play focuses mainly on the plot, Rotrou gets his point across through rhetoric, the raisonnement. While Lope weaves together several different plot strands, Rotrou tends towards focusing on a central conflict and emphasizing the peripeteia. The Genesius-tragédie, as the comparison clearly shows, tends towards formal and aesthetic clarification and towards clarification with regards to the skeptic discourse on perception as well as the subject of religion. In the French version, the 'play within the play' is positioned much more centrally (occupying almost two acts of the entire drama), is more elaborate, and, with regards to the liminality between inner fiction and inner reality, is more distinct. The sense of improvisation, so characteristic of the two inner plays in Lope's drama, is not present here. In Lope's comedia the skeptical unreliability of perception, the indissoluble interplay of fingido and verdadero, is explicitly rendered. Rather than formulate epistemological answers, however, the play uses Catholic dogmatism to 'calming effect,' positing that it only seems to be a problem and that what matters is the belief in the right, and the good play of the right role, the right action. Rotrou's play, on the other hand, in keeping with the spirit of the times in France, seems to convey a tendency towards confronting the skeptical issue and providing an answer to it. Although Le Véritable Saint Genest also displays moments of uncertainty about what is fiction and what is reality, there is much less uncertainty than in Lope. The separation of the inner play from the inner reality, Adrian the character from Genest the actor, and the shifts from fiction to reality are identified and presented transparently to the audience. Rationality is what potentially enables one to distinguish between play and reality, deception and truth. In Lope's drama, Ginés' conversion is well-prepared (first through the theme of sensualerotic love, which in a sense pre-figures true Christian love; then through the presence of the theater of the world metaphor and the concept of human beings as actors playing a role in a world structured by an all-governing God; and finally through the suggested concept of habitualization, etc.). Although the miracle of Ginés' conversion is presented more pompously and concretely in 
comparison to Rotrou's drama, it is arguably also much more complex in terms of interpretation and perception, as expressed through the metaphor of acting and the theater. This is further explored through the extensive use of the theatrum mundi imagery. In the end, in Lope what is ultimately relevant is faith and faith alone. In Rotrou, the miracle of conversion is more abrupt (in Desfontaines the sudden power of divine grace is given even more extreme expression). The supernatural aspects of the Lope drama are played down and reflect a more rationalistic view of religion in keeping with the French setting. Nevertheless, in view of the subject matter, God is still inevitably present and, albeit in a more reduced form than in the Spanish comedia, visible. Rotrou's Christian 'tragedy' is not characterized by the 'hidden God' of Racine's French tragédies, for example. ${ }^{773}$ What manifests itself in the distinctive final image, which in Lope reflects the work's position as part of a 'comedia' in the sense of a Christian 'comedy,' undergoes a clear modification in Rotrou's drama and given a different focus. Rotrou explores more deeply what takes place between the protagonist's conversion and his martyr's death, it is even first mirrored in the 'play within the play' before being realized in the play itself. The believer's convictions, such as heroism in the name of faith and a steadfast belief in eternal life, are given expression.

This comparison of the Spanish and French dramatizations of the Genesius legend highlights two different ways of dealing with the skeptical challenge of the unreliability of sensory perception. In Lope's drama the question is answered not epistemologically but with faith; and its 'message' aligns with that of Calderón (discussed elsewhere in this study), albeit with significant differences in the strategy of representation (including, on the one hand, rhetorical persuasion and, on the other, figural typological structures) and in the degree of vehemence. In Rotrou, however, the decisive frame of reference is not CounterReformation dogma, but the primacy of reason that emerged with Cartesianism. One can, in the French drama, speak of a tendency towards rational inwardness but this is not the internal torment of Hamlet, for example, which is marked by a seemingly unending cycle of irresolution and doubt that does not lead to Montaigne's sense of calmness, but rather ends in despair.

773 Cf. Lucien Goldmann, The Hidden God: A Study of Tragic Vision in the Pensées of Pascal and the Tragedies of Racine [Le dieu caché; Paris 1955], trans. Philip Thody, New York 2013. 